Historic, Archive Document

Do not assume content reflects current scientific knowledge, policies, or practices. 

62.11
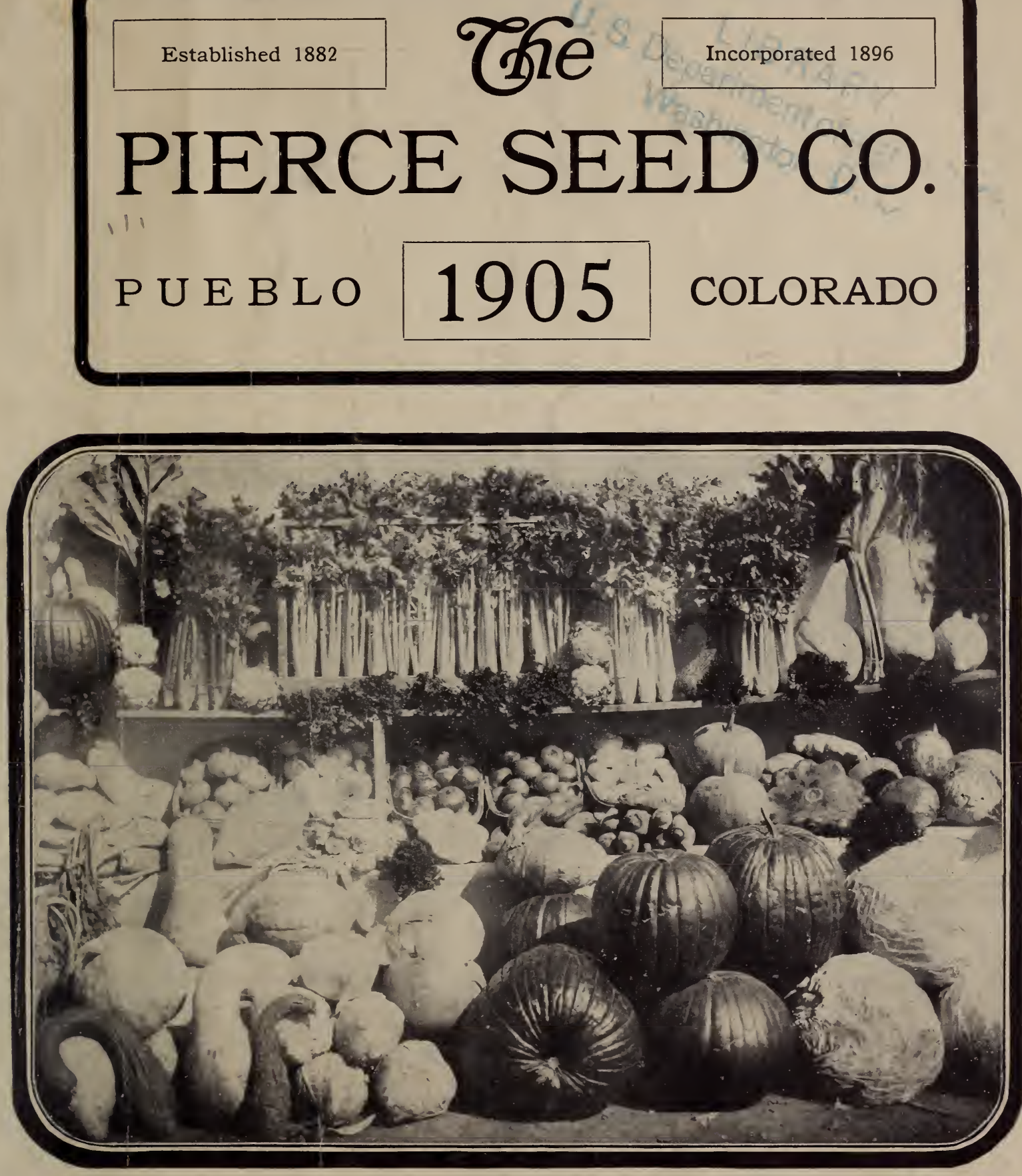

\section{Retail Price List of}

Reliable Grain, Vegetable and Flower Seeds Bulbs and Hardy Perennial Roots 


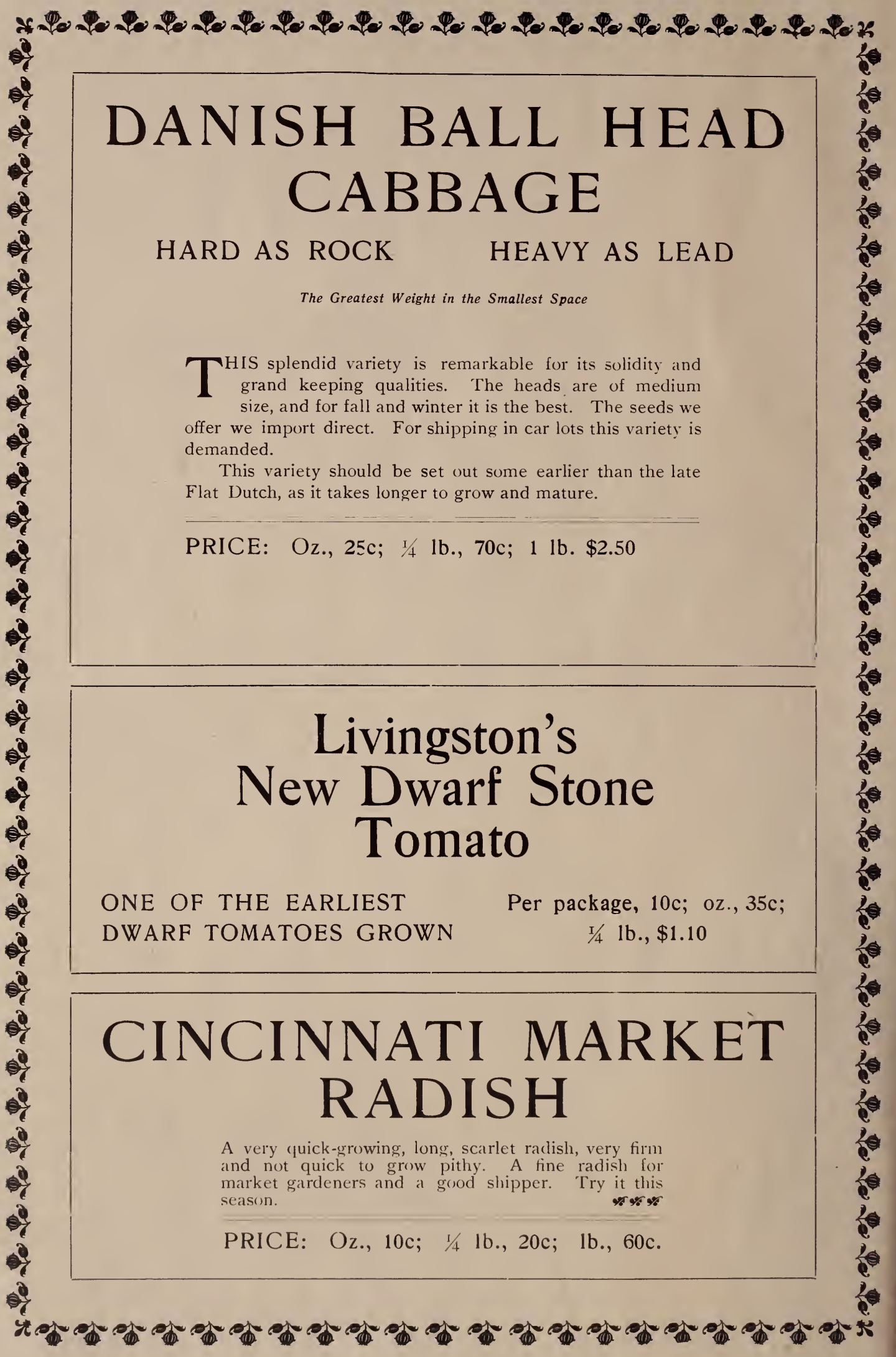




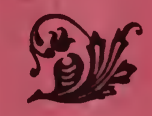 \\ B U L B S

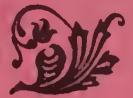

\section{Summer Flowering Bulbs}

Should be put in the ground as soon as the season will permit. A light covering: of old straw or litter will be a good protector from early changeable weather. If you have never grown flowering bulbs, try them this season, as they are much more satisfactory than growing flowers from seeds.

MADERIA-A beautiful showy vine: $5 \mathrm{c}$ each.

\section{DOUBLE PEARL TUBEROSE.}

Height twenty to twenty-four inches. Flower double and large, and very fragrant. Price: Extra large size bulbs 10c, three for 25c, postpaid.

\section{GLADIOLI.}

Pink, red, yellow, variegated and light shades: $5 \mathrm{c}$ each! $40 \mathrm{c}$ per dozen.

\section{CANNAS.}

The most desirable bedding plant; we offer some of the most popular varieties. Price: 10c each: per dozen $\$ 1.00$

AUSTRIA-Green foliage of remarkable strong growth; flowers very large, color pure yellow with light blotches of red in the throat.

AMERICA-The finest red leaved Canna in the giant flowered class. Foliage fine glossy bronze almost as if varnished. Flower extra, large, deep orange, flamed and striped with deeper shade; 4 to 5 feet.

DUKE OF MLAROROUGH-The darkest Canna known; a beautiful crimson maroon; fine metalic green foliage. It is entirely distinct from all others; 3 feet.

ALPHONSE BOUVIER-Green foliage, rich crimson, flower spikes, two and three on a stalk; are very large and full; 6 feet.

FLORENCE VAUGHAN-Yellow ground, thickly dotted with red; height about 3 feet.

ITALIA-Green foliage, bright red, bordered with golden yellow.

MAD. CROZY-Vermillion banded with gold; height about 4 feet.

QUEEN CHARLOTTE-Bright scarlet with a broad band of golden yellow in the center of each petal; 3 feet.

We Prepay Postage on all Garden and Flower Seeds Except Peas, Beans and Corn. 


\section{HARDY PERENNIAL ROOTS and BULBS}

are being planted more each year as their worth is known. Once started they do not have to be replaced each Spring.

\section{PEONIES (Hardy)}

\section{Officinalis Rubra (Old Red).}

Flowers of a bright scarlet crimson, and quite double and globular; very early; only one bloom to the stalk; rare and fine.

\section{EARLY ROSE.}

Early pink variety; blooms right after the Old Red; the flowers are large and in clusters.

\section{ROSEA SUPERBA.}

Fine; full rosy pink; extra choice flower; very free bloomer.

\section{LATE ROSE.} flower.

Similar to Early Rose, only it blooms later in the season. It is a fine rose-scented

\section{ALBIFLORA.}

A grand old Peony; pure white; very large and fragrant; sometimes shows rel streaks in center.

\section{POTTSI.}

Dark purple red; very long stems.

Price: 25c Each; Set for $\$ 1.00$.

HOLLYHOCKS (Mammoth Double Fringed “Allegheny”)

The mammoth flowers are wonderfully formed of loosely arranged fringed petals which look as if made from the finest China silk; mixed colors; $10 \mathrm{c}$ each; $\$ 1.00$ per dozen.

\section{HOLLYHOCK (Double Strong Field Roots.)}

The flowers which are as elegant in shape as a .Camelia, form perfect rosettes of the most lovely shades; separate colors in red, white, yellow, pink and maroon: price 10c each; $\$ 1.00$ per dozen.

\section{PHLOX (Hardy)}

Red, Pink, White, Lavender, Lilac, Deep Purple, Strong; Healthy Roots, 10c Each; \$1.00 Per Dozen, Postpaid.

\section{GOLDEN GLOW (Hardy).}

Double Rudbeckia-One of the brightest and most showy among the hardy plants. and of the earliest culture; grows four to five feet high, producing numerous stems which are laden with double golden yellow flowers, in size and general appearance resembling a Cactus Dahlia; price $10 \mathrm{c}$ each; $\$ 1.00$ per dozen.

\section{BLEEDING HEART}

BLEEDING HEART-(Hardy)-Producing graceful sprays of heart-shaped pink and white flowers; each $25 \mathrm{c}$.

\section{COLUMBINE}

ROCKY MOUNTAIN COLUMBINE ROOTS-Aquilegia-(Hardy)-Can be planted in the fall or early spring. Price per root, postpaid, $10 \mathrm{c}$ to $20 \mathrm{c}$. 


\section{FLOWER SEEDS}

Flower seeds sent by mail on receipt of price. Full culture directions on each package. In our list you will find $A, B$, or $P$ to each variety. A for ANNUALS, which grow, bloom and die the first year from seed. B for BIENNIALS, bloom the second year from seed, then die; though many, if sown early in the spring, will flower the first year. $P$ for PERENNIALS, usually bloom the second year from seed, and continue to grow and bloom for many years: some will also bloom the first year if sown early.

Alyssum, (A) sweet, white ........... 5 Ageratum, (A) Tom Thumb, blue..... 5 Asters, (A) China mixed ............ 5 Asters, (A) Comet mixed ............ 5 Aquilegia, (P) Columbine mixed......5 Bachelor Button, (A) mixed ......... 5 Balsams, (A) double, extra choice mix-

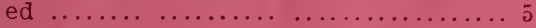
Balloon Vine, (A) $\ldots \ldots \ldots \ldots \ldots \ldots \ldots \ldots \ldots$ Bellis, (P) pure white, double daisy..... 5 Calendula, (A) Pot Marigold, double

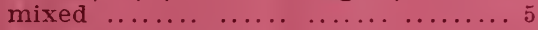
Calliopsis, (A) mixed $\ldots \ldots \ldots \ldots \ldots \ldots \ldots 5$ Campanula, (A) Canterbury Bells ..... 5 Canna, (A) Crozy's finest mixed ...... 5 Candytuft, (A) fine mixed $\ldots \ldots \ldots \ldots \ldots \ldots$ Candytuft, (A) white $\ldots \ldots \ldots \ldots \ldots \ldots \ldots$ j Carnation, (A) double mixed $\ldots \ldots \ldots \ldots .5$ Carnation, (A) Margaret $\ldots \ldots \ldots \ldots \ldots \ldots 5$ Centaurea, (P) Dusty Miller, mixed.... 5 Centaurea, (A) Margaritea, sweet 。 scented $\ldots \ldots \ldots \ldots \ldots \ldots \ldots \ldots \ldots \ldots$ Centaurea, (A) cyanus cornflower...... Ј Celosia, (A) Cockscomb, dwarf mixed... 5 Chrysanthemum, (A) double, mixed.... 5 Chrysanthemum, (A) single, mixed .... 5 Cobea, (A) scandens ............... 5 Columbine, (P) double, mixed ........ 5 Coreopsis, (A) fine mixed ........... 5 Cosmos, (A) fine mixed $\ldots \ldots \ldots \ldots \ldots \ldots$ Ј Cosmos, (A) early mixed $\ldots \ldots \ldots \ldots \ldots \ldots 5$ Cypress Vine, (A) $\ldots \ldots \ldots \ldots \ldots \ldots \ldots \ldots \ldots$ Cucumber, Wild, (A) $\ldots \ldots \ldots \ldots \ldots \ldots \ldots$ j California Poppy, (A) yellow ......... 5 Dahlia, (A) double, mixed .......... 5 Dianthus, (A) China pink, finest double mixed $\ldots \ldots \ldots \ldots \ldots \ldots \ldots \ldots \ldots$ Feverfew, (A) $\ldots \ldots \ldots \ldots \ldots \ldots \ldots \ldots \ldots \ldots$ Four O'Clock, (A) $\ldots \ldots \ldots \ldots \ldots \ldots \ldots \ldots \ldots$ Foxglove, (P) mixed $\ldots \ldots \ldots \ldots \ldots \ldots \ldots \ldots$ Giallardia, (A) $\ldots \ldots \ldots \ldots \ldots \ldots \ldots \ldots \ldots$ Geranium, mixed $\ldots \ldots \ldots \ldots \ldots \ldots \ldots \ldots$ Globe Amaranths, (A) mixed ......... 5 Gourds, (A) ....................... Heliotrope, (P) mixed .............. Hollyhock, (B) Allegheny .......... j
Hollyhock, (P) mixed, double mixed.... 5 Ice Plant, (A) . $\ldots \ldots \ldots \ldots \ldots \ldots \ldots \ldots \ldots$ Larkspur, (P) finest mixed .......... 5 Lantana, (A) mixed $\ldots \ldots \ldots \ldots \ldots \ldots \ldots . \ldots$ Lobelia, fine mixed $\ldots \ldots \ldots \ldots \ldots \ldots \ldots . \ldots$ Marigold, (A) French dwarf ........... 5 Mignonette, (A) large flowered .......5 Mignonette, (A) sweet . ............ 5 Morning Glory, tall .............. 5 Morning Glory, dwarf $\ldots \ldots \ldots \ldots \ldots \ldots 5$ Musk Plant, (A) ................ 5 Myosotis, (P) Blue Forget-Me-Not..... j Nasturtium, dwarf ................. 5 Nasturtium, (A) tall mixed ........... 5 Nicotiana, (A) $\ldots \ldots \ldots \ldots \ldots \ldots \ldots \ldots \ldots$ Pansy, (P) German mixed ........... 5 Pansy, (P) Giant Trimadeau mixed.... 5 Petunia, (A) fine mixed ............. 5 Phlox, (A) Drummondii, mixed ....... 5 Phlox, (A) Star of Quedlinburg, mixed.. 5 Phlox, (P) Perennial mixed ......... 5 Pink. (A) China .................. Poppy, (A) Carnation Flower, mixed... 5 Poppy, (A) Shirley ............... j Poppy, (A) California, yellow ........ 5 Poppy, (A) Iceland, mixed ........... 5 Portulaca, (A) mixed, double $\ldots \ldots \ldots \ldots . \ldots$ Portulaca, (A) mixed, single ......... 5 Salpiglossis, (A) dwarf, mixed ....... 5 Salvia Splendens $\ldots \ldots \ldots \ldots \ldots \ldots \ldots \ldots$ Scabiosa, (A) dwarf, mixed ........ 5

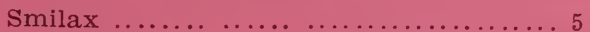
Snapdragon, (A) dwarf, mixed ........ 5 Stocks, (A) large flowering, mixed..... 5 Stocks, (A) Cut and Come Again ...... 5 Sunflower, (A) double, globe shaped.... 5 Sweet Peas, (A) mixed ............... 5 Sweet William, (P) double, mixed ..... 5 Sweet William, (P) single, mixed ...... 5 Verbena, (A) mixed ................ 5 Violet, (P) blue, sweet scented ........ 5 Virginia Creeper $\ldots \ldots \ldots \ldots \ldots \ldots \ldots \ldots \ldots .5$ Wall Flower. German, double mixed.... 5 Wild Cucumber Vine ................ 5 Zinna, (A) dwarf, mixed $\ldots \ldots \ldots \ldots \ldots \ldots$ 


\section{DAHLIAS}

CULTIVATION-While the Dahlia is one of the easiest of all flowers to cultivate, it by no means follows that it requires no attention. In fact, no flower cultivated will give such a generous response to good cultivation as the Dahlia. Deep and thorough stirring of the soil during the early growth of the plant is indispensable to success. The Dahlia, with but few exceptions, should be given an open, sunny situation for at least a portion of each day. It is a rank feeder and should be given a rich soil and kept free from grass and weeds. Cultivation should cease when the blooms appear. After this a liberal supply of water in dry weather will be all they require. Plant the bulbs two or three feet apart, according to the size and habit of the plant. The bulbs should be planted about three or four inches below the surface, laying the bulb on its side. Varieties growing three feet in height should be tied to stakes to prevent falling.

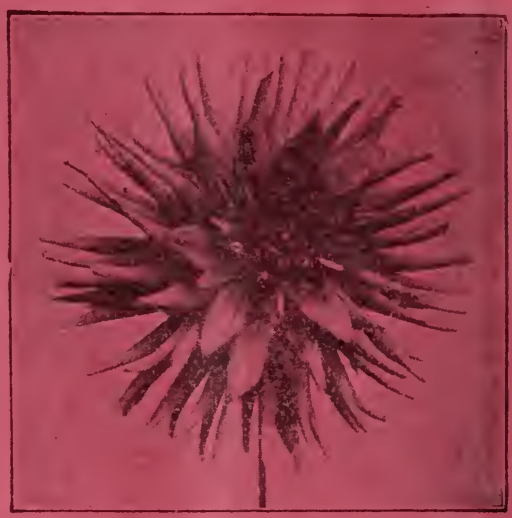

Plant about the first of April in this latitude.

\section{NOVELTIES.}

COUNTESS OF LONSDALE-The freest flowering Cactus Dahlia in the collection, and perfect in form. Color: an exuuisite shade of rich salmon, with just a suspicion of apricot at the base of the petals. Towards the tips the color deepens gradually to the softest carmine pink; 20c each; $\$ 2.00$ per dozen.

KRIEMHILDE-A beautiful cactus form with long pointed petals; color: a beautiful shell pink shading to white at the center. Undoubtedly this variety is the best of its color yet introduced; price, strong roots, $25 \mathrm{c}$ each.

MRS. WINTERS-Its color is a pure waxy white which shows no tint or variation in the strongest sunlight. Very free bloomer producing flowers from 5 to 7 inches in diameter with beautiful pointed petals. About 3 feet high. It is the grandest of all white Dahlias; $25 \mathrm{c}$ each; $\$ 2.50$ per dozen.

\section{DOUBLE VARIETIES.} Price: 15e Each; \$1.50 Per Dozen, Prepaid. Approximate

A. D. LIVONI-Rich pink; finely formed; a very handsome flower $\ldots \ldots \ldots \ldots \ldots \ldots .3$

BON TON-A fine ball-shaped flower of a deep garnet red; sometimes tipped and

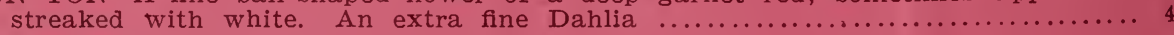

SNOW-A beautiful pure white, long stems, excellent for cutting $\ldots \ldots \ldots \ldots \ldots \ldots . . .4$

MISS DODD-Purest yellow, of exquisite form and color; a remarkably handsome

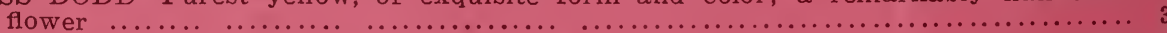

FLORAL PARK JEWEL-Rich purple red, tipped and striped with white; some-

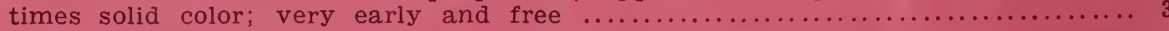

KAISER WILHELM-One of the grandest flowers in cultivation; of immense size and perfect form; deep yellow, tipped and shaded with cherry red $\ldots \ldots \ldots \ldots \ldots 41 / 2$

IGNACIO-A remarkably healthy, strong-growing plant, with long stems and large,

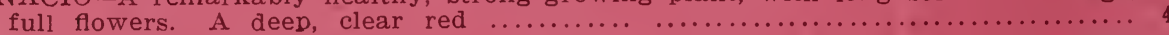

PURPLE GEM-Rich royal purple, clear and constant; this variety is a decided

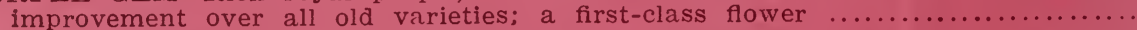

GLORY DE LYON-The largest white Dahlia in cultivation; almost round as a ball 3

HENRY PATRICK-Pure white; this is one of the very best; flowers are very

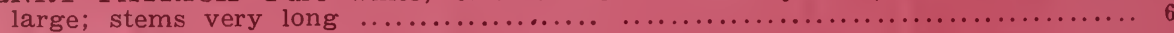

ORINE EMERSON-A very, handsome flower, borne on long stems. Color: rich

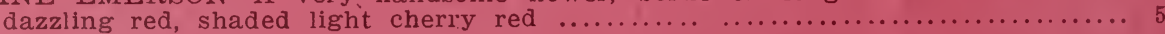

JOHN LAMONT-A bold dark maroon flower produced freely on long stems; fine

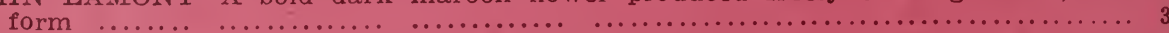

GEN. CUSTER-Deep purple maroon; long stems and a very free bloomer.......4

LADY MILDWAY-A very beautiful flower; white ground, shaded to pink; very

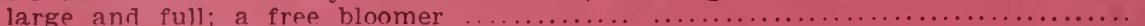




\section{DAHLIAS---Continued \\ CACTUS VARIETIES.}

\section{One to Three Strong Germs to Each Bulb.}

The Cactus Dahlias are comparatively new. They are distinguished from the ordinary type by their broad flat petals, which are sometimes twisted. They possess all the richness of color found in other types, while they surpass them in point of usefulness. Florists now use the cactus types almost exclusively for cutting and decorative purposes.

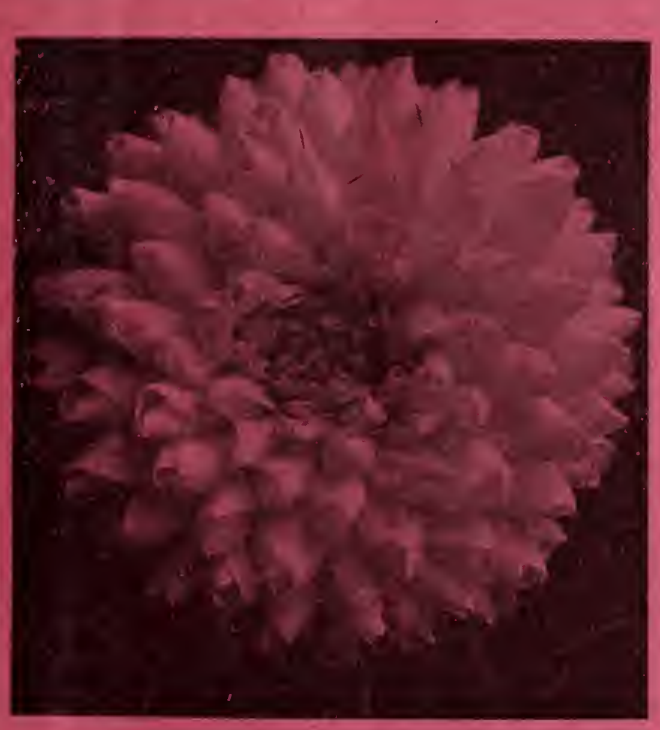

Approximate

Feet High

GRAND DUKE ALEXIS-Very large; its petals are beautifully quilled; color is pure white when slightly shaded, but overspread with delicate lavender when grown in bright sunlight ....... $4 \frac{1}{1} 2$

IFS. BARNES - A beautiful primrose color; flowers well forned; a free bloomer ........

LYDIA DIETER - A beautiful soft lavender shade; one of the most attractive color in the entire collection $\ldots \ldots \ldots \ldots \ldots \ldots \ldots$

LYNDHURST-Scarlet or vermillion; distinct in its color from all others; a noble flower.......

GLORISA-Long, narrow petals, like a chrysanthemum; color', rich in scarlet; one of the best
cactus types yet produced.........

MRS. PEART-This is one of the queens among Dahlias and the best of its type ever introduced: it has the appearance of a white chrysanthemum with its long pointed petals; its color is a delicate creamy white; a companion for Glorisa .................... 3

Grand Duke Alexis.

ARACHNE-(Cactus)-A most remarkable flower. The center of each petal is
pure white edged along its entire length with broad band of brightest crimson. As, however, the edges of the petals are completely reflexed, the white only of the outer petals is seen when looking straight into the face of the flower; sideways the reflexed crimson edges are fully visible $\ldots . . . \ldots \ldots \ldots \ldots$.

GOLDEN TREASURE-A beautiful burnt orange color; flowers large and full;

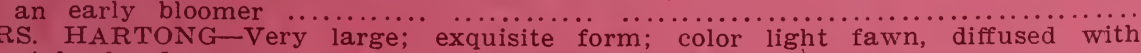

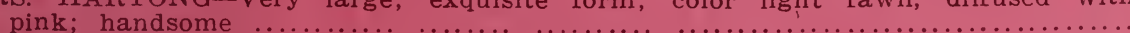

MATCHLESS-Petals long and pointed, very evenly arranged; has been awarded 18 first-class certificates in England alone; it possesses all the qualifications of flrst-class variety; color, almost a black maroon ...................................

EARL OF PEMBROKE-A grand Dahlia, looking more like a chrysanthemum; petals very long and narrow; flowers perfectly formed; quite full to center;

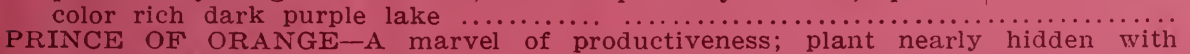
the large, well formed flowers; rarely a deformed flower seen; color, apricot,

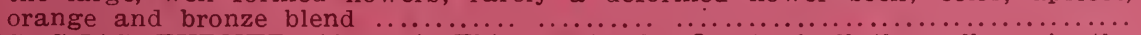

MRS. CHAS. TURNER-(Cactus)-This one is the finest of all the yellows in the cactus varieties. Extra large with long pointed petals and perfect form.

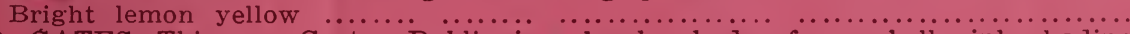

DR. GATES-This new Cactus Dahlia is a lovely shade of sea shell pink shading to blush at the base of the petals. Unlike so many of the cactus varieties, this one has a fine stem, holding its flowers well above the foliage. Its flowers are very even in size and form. As a variety for cutting it has no equal among

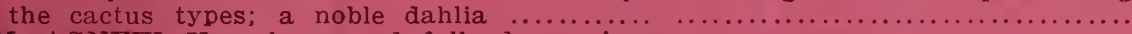

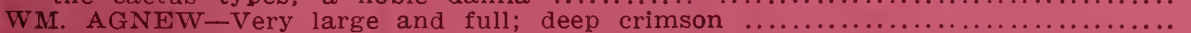

MRS. LINDER-This new decorative Dahlia we consider one of the best. Its color is a beautiful creamy white, shading to blush pink. Of perfect outline.......

GRAND MOGUI-Intense scarlet, variegated with pure white, frequently a solid

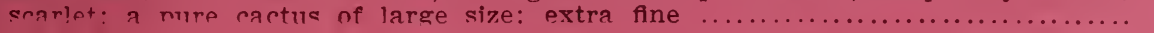




\section{FLOWERING SWEET PEAS}

Straight Colors 10c per Ounce

\begin{abstract}
PREPARING THE SOIL-Select a warm, sunny place and if possible, prepare the ground in the fall by a liberal application of well rotted manure. If your soil is adobe, use old coarse manure, and fine manure in the spring. Place the fine manure as much in the trenches as possible.
\end{abstract}

SOWING THE SEED-After you have the soil well prepared, make a trench six inches deep, sow the seed about two inches apart in the trench, cover two inches. As the vines grow, draw the earth up to them until the ground is level or slightly lower between the rows. Another way: Make two trenches six inches deep from six to eight inches apart and the double rows from eighteen inches to two feet apart making the ground lower between the rows.

A FEW HINTS-Prepare the ground and get the seed in as early as poissible.

Have the ground moist (not soggy wet) when you sow the seed.

Do not irrigate until the plant is through the ground, sprinkle rows to keep the ground moist.

When nicely started, do not let them want for water; sprinkle the vines two or three times a week, but not in the heat of the day.

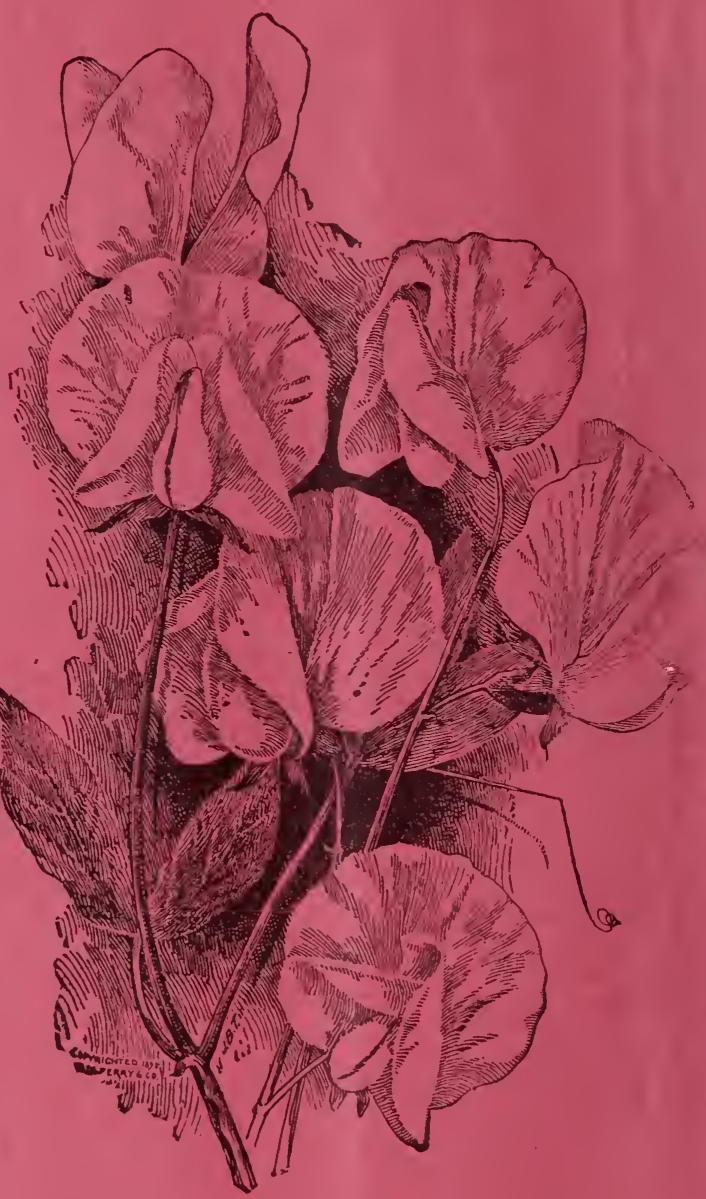

A small quantity of fertilizer mixed with the ground in the bottom of the trench before planting is very beneficial and the plant appreciates mulching.

Keep all flowers cut off if you want continuous bloom. When they go to seed that ends flowers.

OUR FLOWERING SWEET PEAS ARE THE BEST.

We Pay Postage on Sweet Peas and Other Flower Seeds. 


\section{FLOWERING SWEET PEAS \\ SOME OF THE MOST SATISFACTORY VARIETIES GROWN. WHITE.}

MRS. SANKEY - Pure white; largest size; profuse bloomer.

BLANCH BURPEE-Pure white: immense size.

EMILY HENDERSON-Pure white.

\section{IIGHT YELLOW, ORANGE OR SALMON.}

STELLA MORSE-Large flowers. A combination yellow and pink which is quite distinct and very attractive.

PRIMROSE-Pale primrose yellow.

GORGEOUS - Scarlet, orange and rose tinged; fine.

\section{LIGHT SHADES OF PINK.}

KATHERINE TRACY-(New)-Soft brilliant pink.

VENUS-Salmon-buff; standard; delicately shaded with rose pink.

MRS. ECKFORD-Thite shaded with pink.

SENSATION-White suffused with faint rose.

PEACH BLOSSOM-Large; standard; heavily shaded with soft rose on silvery white. APPLE BLOSSOM-Bright pink and blush; beautifully shaded.

\section{DARK SHADES OF PINK.}

HER MAJESTY-Beautiful soft rosy pink; large flowers.

ROYAL ROSE-Fine deep rose colored.

\section{MAUVE.}

LADY NINA BALFOUR-Very beautiful mauve.

\section{SHADES OF RED.}

FIRE FLY-Very bright crimson scarlet.

BRILLIANT-Bright crimson scarlet.

SALOPIAN-Brilliant scarlet.

CAPTIVATION-Light magenta.

\section{RED AND WHITE, LIGHT WINGS.}

EXTRA EARLY BLANCHE FERRY-Pink and white; extra early variety.

BLA YCHE FERRY-Pink and white.

LITTLE DORRET-Pink; standard; white wings.

\section{SCARLET AND MAROON.}

BOREATTON-Bronze, crimson and purple.

BLACK KNIGHT-Deep maroon self-color.

SHAZADA-Dark maroon with a tint of purple in standard inner portion of wings.

\section{LAVENDER AND LIGHT BLUE.}

COUNTESS RADNOR-Delicate lavender.

LOTTIE ECKFORD-Rose and white, edged with blue.

\section{BLUE AND PURPLE.}

COUNTESS CADOGAN-Redish mauve. standara, wings violet blue.

NAVY BLUE-

CAPTAIN OF BLUES-Dark navy blue.

\section{STRIPED OR VARIEGATED.}

AMERICA-Bright blood red, striped white.

SENATOR-Chocolate and creamy white, mottled and blotched.

\section{DWARF CUPID MIXED.}

Price: Ounce 10c; 3 ounces for $25 \mathrm{c}$. on all above varieties.

ECKFORDS-Finest mixed; $10 \mathrm{c}$ oz.: 4 ozs. $25 \mathrm{c} ; 75 \mathrm{c}$ to.

Choice finest mixed; $5 \mathrm{c}$ oz.; 4 ozs. $15 \mathrm{c} ; 40 \mathrm{c}$ tb.

SWEET PEAS-Postpaid at above prices.

Our Sweet Peas are Fine-None Better. 


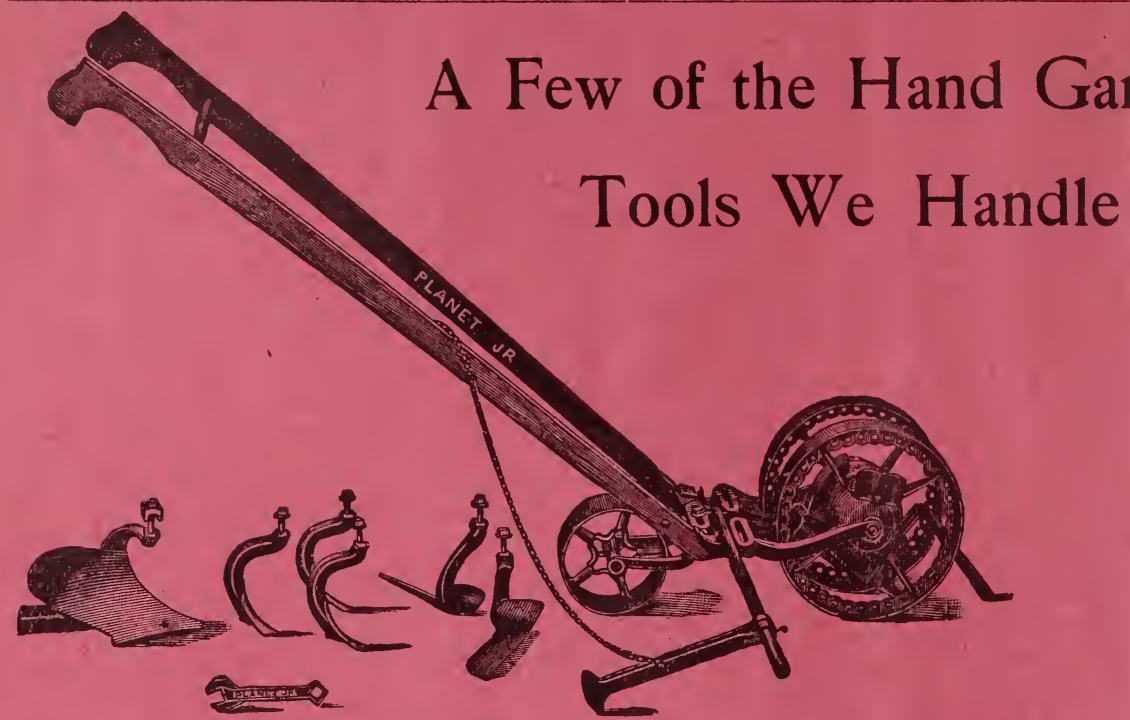

PLANET JR. No. 1-Combined Drill and Wheel Hoe, $\$ 9.50$.
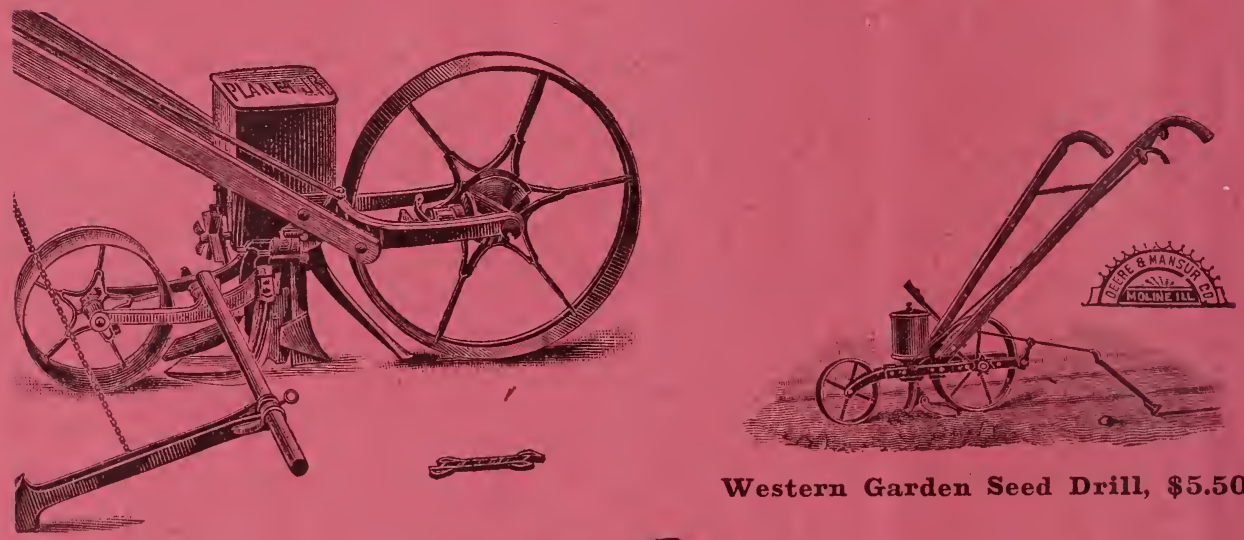

Western Garden Seed Drill, $\$ 5.50$.

PLANET JR.

Hill and Drill Seeder (plain). As a Drill only, $\$ 8.50$.

\section{PLANET JR.}

Double Wheel Hoe with Hoes and Cultivators, $\$ 5.00$.

With Hoes, Cultivators, Plows and Rakes, $\$ 9.00$.

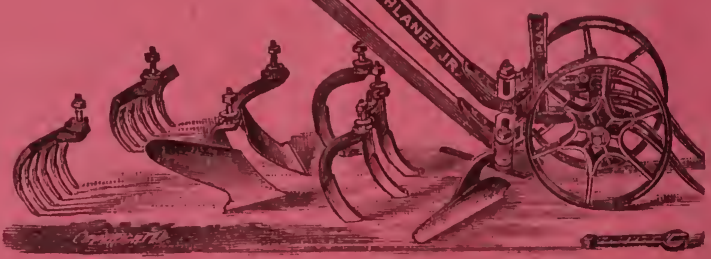


$\frac{1905}{q}$

$\frac{1905}{q}$

\section{THE}

\section{Pierce Seed Co.}

RETAIL LIST OF

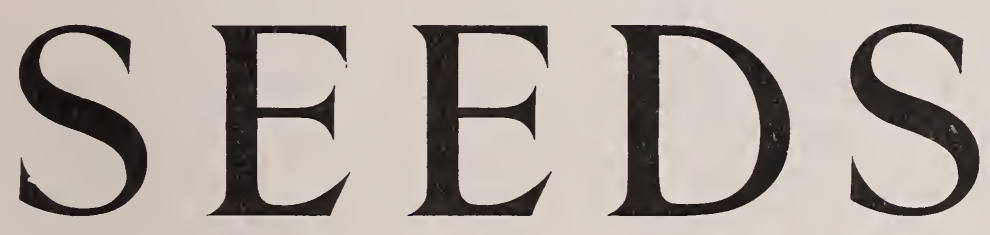

216 WEST FOURTH STREET,

NEW POPE BLOCK

PUEBLO, COLORADO 


\section{Twentieth Annual Catalogue}

\section{\% $O F \quad \%$ \\ The Pierce Seed Co.}

\section{Reliable Seeds}

We offer seeds grown by the best growers in the United States and foreign countries. Some varieties of seeds will be short again this season, so do not delay, but place your order early.

When in the city ask for the PIERCE SEED CO.'S store. You are always welcome.

Our mail order business is increasing each year, and we are prepared to fill orders promptly. We prepay postage on vegetable or flower seeds in ounce packet orders; by the pound if sent by mail, must be accompanied with eight cents for each pound so ordered, except when stated otherwise.

Money must be sent by Money Order, Registered Letter or Draft.

Of all seeds quoted in the $100-1 b$. lots, 25 pounds will be furnished at the same rate per pound.

We sell packets of any seeds quoted, at $5 \mathrm{c}$ and $10 \mathrm{c}$ per packet. sold.

Prices subject to market change and present stock un-

\section{Terms: Cash With Order}

OUR WARRANTY.-A great many ask us if we warrant our seeds to grow. We do not in any respect. We believe the seeds we offer are unsurpassed in quality. Experience has proven that the same seed sown under different circumstances, and by different parties, produce different results, showing that a dealer, if he warrants seeds, must put such a price on his goods as to cover a certain per cent of loss, and the guarantee does not cover the cost of the crop lost.

Among the many causes of failure are: The soil may be unfavorable to the variety sown; or, the soil may be all right but the weather such as to destroy the germ in the seed.

Hoping to hear from you, we are

Yours respectfully,

The Pierce Seed Company,

Address P. O. Box 495.

Pueblo, Colorado. 


\section{SUGAR BEETS and MANGEL WURZEL FOR STOCK FEED}

Sugar Beets and Mangel Wurzel have proven a great success among our most progressive ranchmen, and especially to the dairymen around Pueblo. Mangel Wurzel yield from 20 to 40 tons per acre. Sugar Beets from 12 to 30 tons per acre. Some prefer the sugar beets for hog feed.

CULTURE-As all Mangels require a deep soil in order to grow well, plow and subsoil from a foot to eighteen inches, and apply plenty of rich stable manure. Sow from April 10 to last of May, 4 to 5 pounds to the acre, in rows 18 inches to 2 feet apart, and thin to 18 inches in the rows. As soon as frost occurs dig the crop. In order to be well preserved for gradual consumption during the winter, Mangel Wurzel should be heaped to a height of four to six feet on a dry sloping situation, cover lightly with straw, hay or corn stalks and enough soil to keep the covering from blowing off. As soon as this soil becomes frozen, cover all about eight or ten inches deep with more soil. By following up this gradual process of covering, all danger of heating will be obviated and the roots will keep in perfect order.

PRICE - Mangel Wurzel, Mammoth Long Red, per pound, 30c; 10 pound lots, per tb., $25 \mathrm{c}$.

Mangel Wurzel, Yellow Globe, per tb., 25c: 10 pound lots, per tb., $20 \mathrm{c}$.

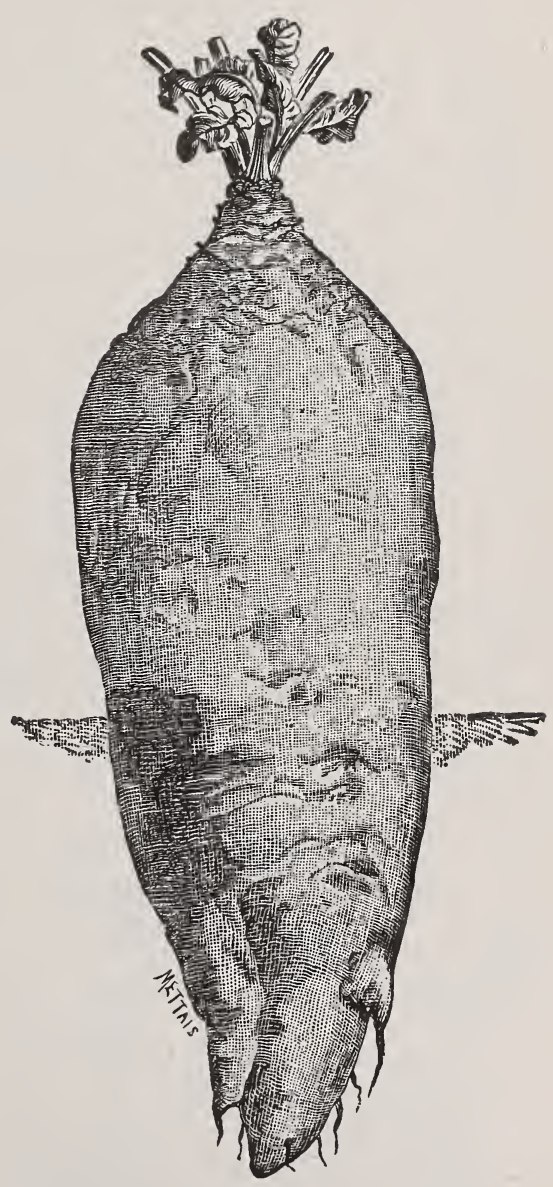

\section{GOLDEN TANKARD}

Valuable yellow fleshed variety, said to contain a large per cent of sugar; very productive; matures early, growing nearly all above ground; is very easy to harvest; price per tb., 30c; 10-lb. lots, $25 \mathrm{c}$ per tb.

Sugar Beets-Lane's Imperial Sugar ................... per tb., 30c

Sugar Beets-White French Sugar ................... per to., $30 \mathrm{c}$

10 Pound Lots ........................................ $25 \mathrm{c}$ 


\section{Catalogue of Seeds}

\section{ASPARAGUS}

Sow in drills one foot apart, and when the plants are four or five inches high they should be thinned out so that the plants will be nine inches apart in the rows. Keep the weeds down thoroughly the first year, else they choke down the young seedlings. The deeper the soil and greater the abundance of manure that is used, the greater the crop. The experience of Colorado gardeners is that Asparagus can be cut from one to two years earlier than in the east. It is the most profitable crop grown on the market. COLUMBIAN WHITE MAMMOTH-This is a very large white

Asparagus; it furnishes white shoots which stay white as

long as.fit for use. Seed produces 80 to 90 per cent of white plants; oz. 10c; $1 / 4$ tb. $25 \mathrm{c}$; tb. $75 \mathrm{c}$.

CONOVER'S COLOSSAL-A standard variety; oz. $10 \mathrm{c} ; 1 / 4$ 1b. $15 \mathrm{c}$; tb. $50 \mathrm{c}$.

WE CAN SUPPLY ASPARAGUS ROOTS IN SEASON.

Two-year-old roots, per doz. $25 \mathrm{c}$; per $100, \$ 1.50$; special price pel 1,000 .

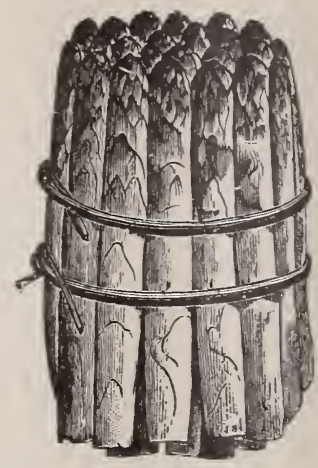

\section{BEANS}

Select light warm soil; plant when danger of frost is past in Spring, about two feet apart: seeds about two inches in drills; cover one inch deep.

\section{DWARF OR BUSH.}

IMPROVED RED VALENTINE-Green pods; two weeks earlier than any other valiety of Valentine; nearly whole crop can be picked at one time; desirable for marke gardeners; tb. 15c; 100 lbs. $\$ 12.50$.

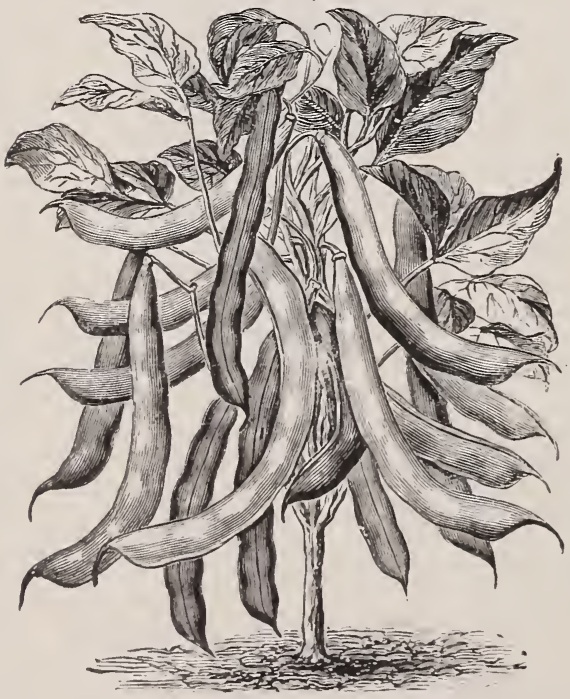

EARLY LONG YELLOW SIX WEEKS-Green pods, a standard; tb. $15 \mathrm{c} ; 100$ fbs. $\$ 12.50$.

REFUGEE-Green pods; a very prolific bush sort; pods round: fine flavor; used extensively for canning; to. $15 \mathrm{c} ; 100$ ths. $\$ 12.50$.

DAVIS WHITE KIDNEY WAX - Very productive; early : rustless: its commercial value as a white kidney bean is unsurpassed; in time of over production as a snap bean, let them go to seed and they will sell as a dry bean; ib. $15 \mathrm{c}$.

FLAGEOLET CRIMSON WAX -Yellow pods: very fine long waxy golden pods; very productive, tender, delicious, and a good variety for market garden use; to. $15 \mathrm{c}$.

Write for Special Prices on Beans in Large Quantities. 


\section{BEANS---Continued}

BROAD WINDSOR-The largest and best of the class of English dwarf bean: beans are eaten shelled; ib. $15 \mathrm{c}$.

GOLDEN WAX OR BUTTER-Yellow pods; stringless; early and fine quality; very desirable; tb. $15 \mathrm{c} ; 100$ tbs. $\$ 12.50$

BLACK WAX-Yellow pods: stringless; earliest of wax rarieties; superior for bean coup; 1b. $15 \mathrm{c} ; 100$ tbs. $\$ 12.50$

WARDIVELL'S KIDNEY WAI-Yellow pods; very productive: pods long, broad, flat and of a very delicate yellow; brittle and entirely stringless; beans white and redish purple at the eye; kidney shape; a very desirable market garden sort; 1b. 15c; 100 tbs. $\$ 12.50$.

WHITE WAX-Fellow pods: stringless; pods fair size; very rich, tender and productive; almost as transparent as glass; $1 \mathrm{~b} .15 \mathrm{c}$.

MEXICAN LIMA-A large oval-shaped bean used in green state, same as limas and considered very fine when dry; they require no poles, being a dwarf bush bean; tb. $15 \mathrm{c}$.

WHITE MARROWFAT-Extensively grown for winter use: very productive; to. 10c.

CRYSTAL WAX-Light green pods; pods of fair size; rich and tender; in color, waxy white; is a stringless variety; very productive; 1b. $20 \mathrm{c}$.

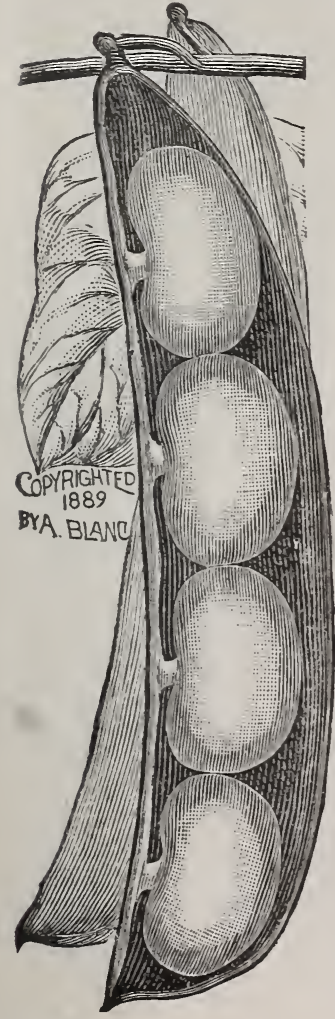

BURPEE'S DWARF OR BUSH LIMA-A perfect bush form of true, luscious, large lima bean; bushes grow from 18 to 20 inches high, of stout growth, yet branching vigorously; an immense yielder; the dry beans are larger than Henderson's Bush Lima; tb. 15c.

NAVY-Market price.

MEXICAN-Market price. Our Mexican bean seed is the best strain. Last season one acre produced 2,800 pounds beans from our Mexican beans.

\section{BEANS-Pole or Running.}

EXTRA EARLY LIMA-This new Lima bean has all the good qualities of the Limas, but is much earlier, which makes it a good acquisition to Colorado; 1b. 15c.

LAZY WIFE-Pods long, dark green color; thick and fleshy, and very productive; tb. $15 \mathrm{c}$.

SCARLET RUNNER-Cultivated for the beauty of its flowers; also for a useful vegetable; tb. 15̄c.

GOLDEN BUTTER-A new German wax pole; early and prolific; a good bearer; pods rather long and fine flavor; $1 \mathrm{~b} .15 \mathrm{c}$.

DUTCH CASE KNIFE-An early variety: lage pods: very productive; good for shell beans; tb. $15 \mathrm{c}$.

KENTUCKY WONDER OR OLD HOMESTEAD-This most popular variety is an improved large strain of Southern prolific. They are solid, meaty and stringless when young of fine quality. If pods are gathered as they mature the vines will continue to bear to the end of the season; $1 \mathrm{~b} .20 \mathrm{c}$.

Twenty-five pounds of Beans sold at 100 pound rate. 


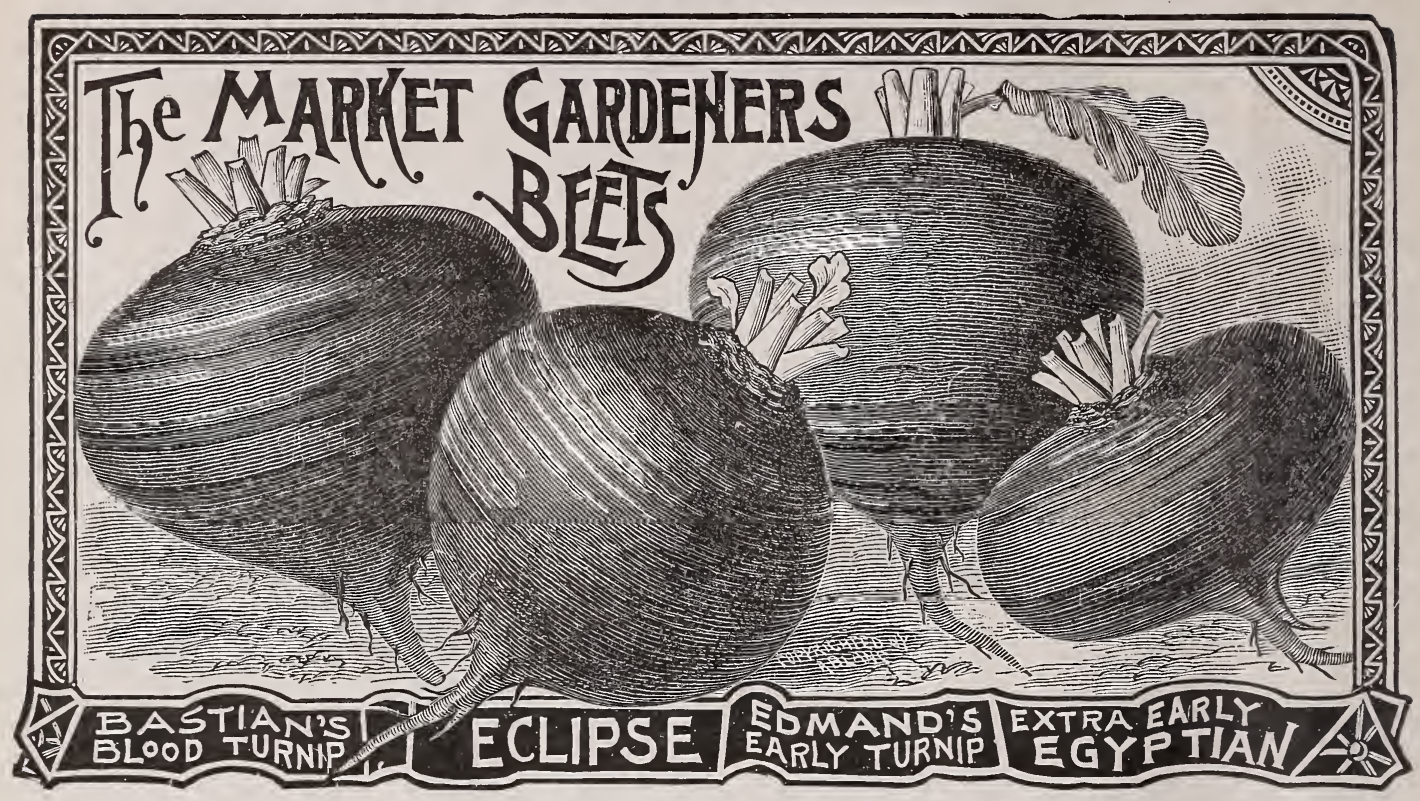

Beets require a rich soil. Sow in drills 14 to 16 inches apart, one inch in depth; thin to four or five inches. For early use sow as soon as ground can be worked in the spring.

EDMOND'S BLOOD TURNIP-A second early and late variety of handsome round shape; the skin is a very deep blood red; flesh also very dark; exceedingly sweet and tender in quality; they do not grow large, but of a good uniform size; good for bunching; oz. $10 \mathrm{c}$; $1 / 4$ tb. $20 \mathrm{c}$ : 1b. $60 \mathrm{c}$.

NEW ECLIPSE-An early variety; globe shape; small top; very sweet; flesh fine. dark blood color; oz. 10c; $1 / 4$ tb. 20c; ib. $60 \mathrm{c}$.

DEWING'S IMPROVED EARLY BLOOD TURNIP-Very early; grows to large size oz. $10 \mathrm{c} ; 1 / \mathrm{h}$ Ib. $20 \mathrm{c}$; Ib. $60 \mathrm{c}$.

LONG BLOOD-A long red beet; oz. 5c; 1/4 1b. 15c; 1b. $50 \mathrm{c}$.

CROSBY'S IMPROVED EGYPTIAN-A very superior strain of blood-red Egyptian, not so flat as the ordinary Egyptian; forms turnip-shaped beets in its early growth,

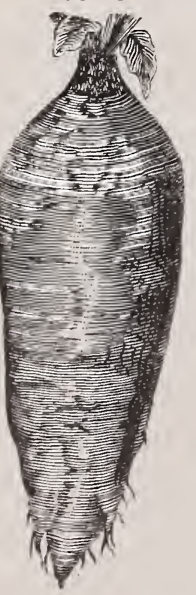
thereby making it a very desirable early variety for bunching; few small tops, very small tap root; of very fine quality; oz. $10 \mathrm{c} ; 1 / 4 \mathrm{th}$ 20c: 1b. 60c.

EARLY BLOOD TURNIP-Old standard variety; early, tender, sweet: keeps well; oz. $5 \mathrm{c}$; $1 / 4$ tb. $15 \mathrm{c}$; tb. $50 \mathrm{c}$.

WHITE FRENCH SUGAR-Although a sugar beet, it is extensively grown for stock feed; tb. 30c; 10-tb. lots $25 \mathrm{c}$ ib.

LANE'S IMPROVED SUGAR-An improvement on the White French Sugar; hardy; very productive; contains a large per cent of sugar: tb. $30 \mathrm{c}: 10-1 \mathrm{~b}$. $\operatorname{lots} 25 \mathrm{c}$ Ib.

\section{MANGEL WURZEL-Stock Feeding Varieties.}

MAMMOTH LONG RED-One of the largest and best croppers; fine quality; 1b. 30c: 10-1b. lots $25 \mathrm{c}$ tb.

YELLOW GLOBE MANGEL-Large variety; good keeper; 1b. 25c: 10 - Ib. lots $20 \mathrm{c}$ tb.

GOLDEN TANKARD-1b. 30c; 10-1b. lots 25c ib.

\section{BRUSSELS SPROUTS.}

IMPROVED HALF DWARF-The very best and surest strain; oz. 15e; $1 / 4$ ib. $50 \mathrm{c}$ : $1 \mathrm{~b}$. $\$ 2.00$.

\section{Special Prices on Plants.}




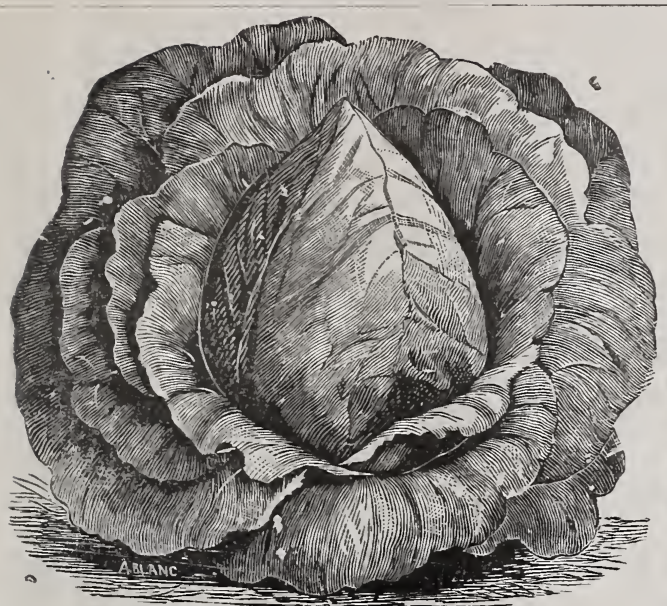

Early Jersey Wakefield.

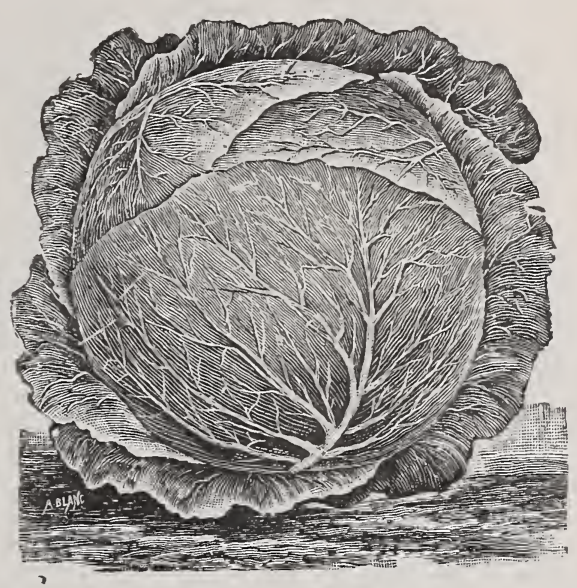

Excelsior Flat Dutch.

\section{CABBAGE}

Our cabbage seed is the finest Long Island grown. Cabbage will thrive on any good land. Plow deep and manure freely. The early varieties are sown in hot beds in February; the late sorts in the month of June. Plant in rows about 20 inches apart, two feet between the rows.

EARLY JERSEY WAKEFIELD-(True Seed)-The most popular and valuable early variety; sure to head; good size; pyramidal in shape; oz. $25 \mathrm{c} ; 1 / 4 \mathrm{tb}$. $60 \mathrm{c} ; 1 \mathrm{~b}$. $\$ 1.85$.

THE CHARLESTON OR LARGE EARLY WAKEFIELD-The same shape and character as the Early Jersey Wakefield, but larger; oz. 25c; 1/4 to. 60c; to. \$2.00.

EARLY FLAT DUTCH-A first-class second early; round, flat variety; oz. 20c; 1/4 Ib. $50 \mathrm{c}$; to. $\$ 1.50$.

HENDERSON'S EARLY SUMMER-The earliest large heading cabbage; growth very compact and a desirable sort; oz. 20c; $1 / 4$ tb. $50 \mathrm{c}$; 1b. $\$ 1.75$.

EARLY WINNINGSTADT-Heads cone shaped and solid; oz. 20c; 1/4 ib. 50c; tb. $\$ 1.50$.

EARLY CANNON BALL-The hardest heading of all early varieties; oz. 20c; $1 / 4 \mathrm{Ib}$ $60 \mathrm{c}$; 1b. $\$ 2.00$.

DIAMOND WINTER-Heads extra hard and solid; medium size; sure header; a good cabbage for this locality; oz. $30 \mathrm{c} ; 1 / 4$ tb. $75 \mathrm{c}$; to. $\$ 2.75$.

DEEP HEAD-An excellent cropper and sure to head; oz. 15c; 1/4 1b. 50c; 1b. $\$ 2.00$.

SURE HEAD-All head and always sure to head; late variety; oz. 15c; 1/4 1b. 60c; 1b. $\$ 2.00$.

PREMIUM FLAT DUTCH-A fine strain of Flat Dutch; extensively grown for fall and winter use; oz. $15 \mathrm{c}$; $1 / 4$ 1b. $50 \mathrm{c}$; 1b. $\$ 1.50$.

EXCELSIOR FLAT DUTCH-One of the best Flat Dutch; late sort as can be grown; is a good keeper; oz. $20 \mathrm{c} ; 1 / 4$ 1b. $60 \mathrm{c}$; 1b. $\$ 2.00$.

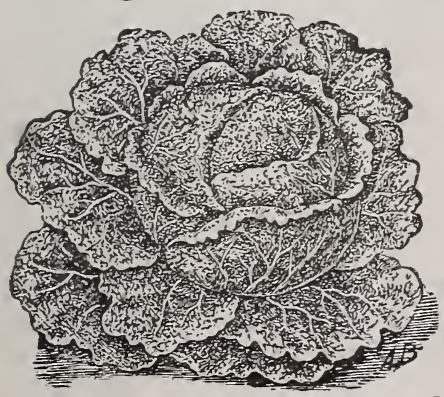

ALL SEASON-A valuable market gardener's variety; heads very hard and solid; round; flattened on top; nearly as early as Early Summer and much larger; it is called All Season because it is as good for autumn or winter as it is for early; oz. $15 \mathrm{c} ; 1 / 4 \mathrm{tb} .50 \mathrm{c}$; 1b. $\$ 1.75$.

SAVOY NETTED-This is the finest of the Savoy class; heads large, very solid and compact; oz. 20c; $1 / 4$ ID. $60 \mathrm{c}$.

RED DUTCH PICKLING-Very valuable for pickling: oz. $20 \mathrm{c} ; 1 / 4$ Ib. $70 \mathrm{c}$.

See Special Prices for Plants on Page 32.

All Our Plants are Hardened. 


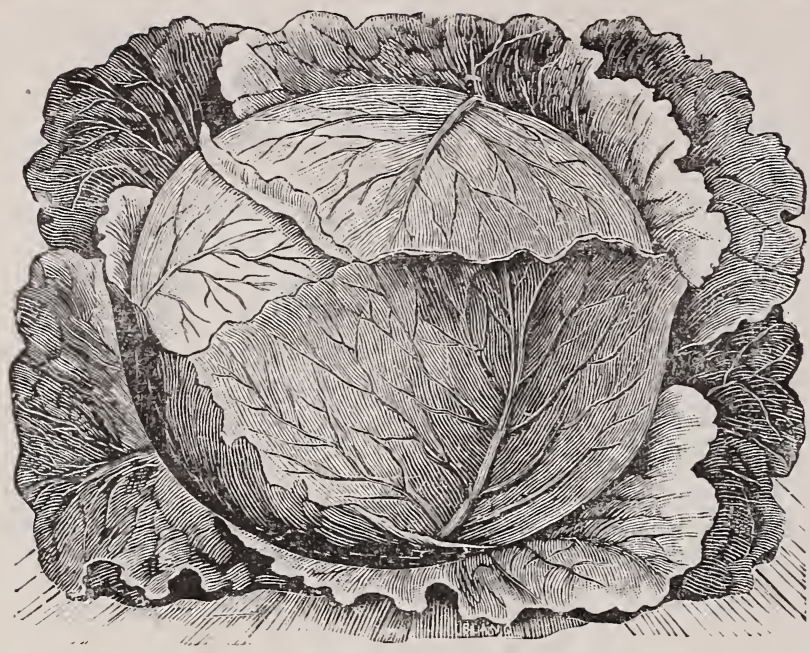

Flat Dutch.

\section{CABBAGE}

M A R K E GARDENER'S NO. 2-One of the best second early or summer sorts; grown very extensively by a few market gardeners near Pueblo and considered a very profitable variety: heads are solid, of medium size; oz. $45 \mathrm{c} ; 1 / 4$ 1b. $\$ 1.20$; 1b. $\$ 4.50$.

DANISH BALL HEAD-OZ. $25 \mathrm{c} ; 1 / 4$ tb. $70 \mathrm{c}$; to. $\$ 2.50$.

HENDERSON'S SUCCESSION-Whether grown as a second early or main late crop, it has no equal; as second early it is a few days later than Early Summer; heads are slightly larger, more perfect and uniform in size; handsome color; of the finest quality; a good keeper; oz. 20c; $1 / 4$ ib. $60 \mathrm{c}$ : ib. $\$ 1.75$.

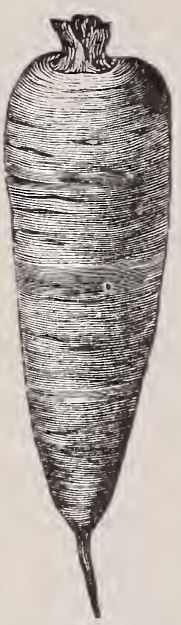

Long Orange.

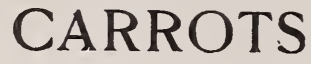

Sow in early spring in rows from ten to fifteen inches apart; require rich, deep, mellow soil; thin to about four inches apart.
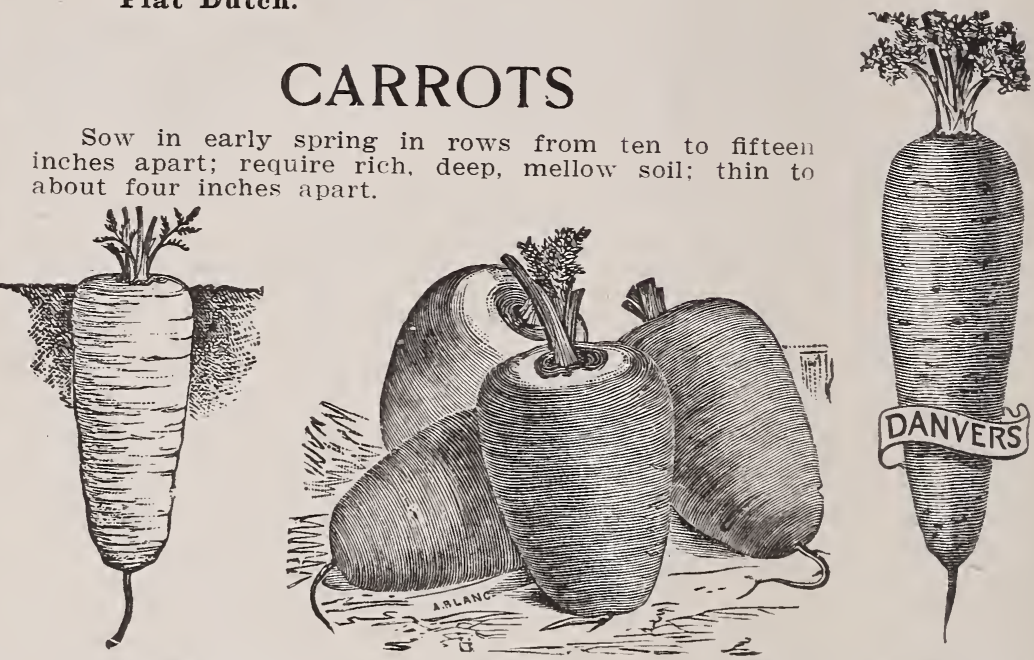

Ox Heart.

Half Long Danvers.

SMALL FRENCH FORCING-The earliest variety; mostly used by gardeners for forcing; oz. 10c: $1 / 4$ th. $30 \mathrm{c}$; to. $90 \mathrm{c}$.

GUERANDE OR OX HEART-A new French Carrot; it is intermediate between the half-long and long varieties; of most beautiful shape and color; oz. $10 \mathrm{c} ; 1 / 4 \mathrm{Th}$. 25c: 1b. $75 \mathrm{c}$.

EARLY SCARLET HORN-A fine variety of medium size; fine flavor; oz. 10c; 1 Ib. $25 \tilde{c}$ : 1b. $80 \mathrm{c}$.

HALF LONG SCARLET-(Stump Root)-An excellent variety, and good for shallow soil; oz. 10c; 1/4 1b. $25 \mathrm{c}$; 1b. $80 \mathrm{c}$.

EARLY HALF LONG DANVERS-One of the most productive and one of the best for field culture; sweet and tender; oz. 10c; 1/4 ib. $20 \mathrm{c}$; 1b. $70 \mathrm{c}$.

IMPROVED LONG ORANGE-The standard field carrot; oz. 10c; 1/4 Ib. 25c; tb. $80 \mathrm{c}$.

WHITE BELGIAN-When young the roots are mild and delicate, and when full grown are valuable for stock; oz. 10c: 1/4 tb. $25 \mathrm{c}$; 1b. $80 \mathrm{c}$.

Use Fancy Kentucky Blue Grass and White Clover for Lawns. 


\section{CAULIFLOWER}

Requires the same treatment and culture as cabbage.

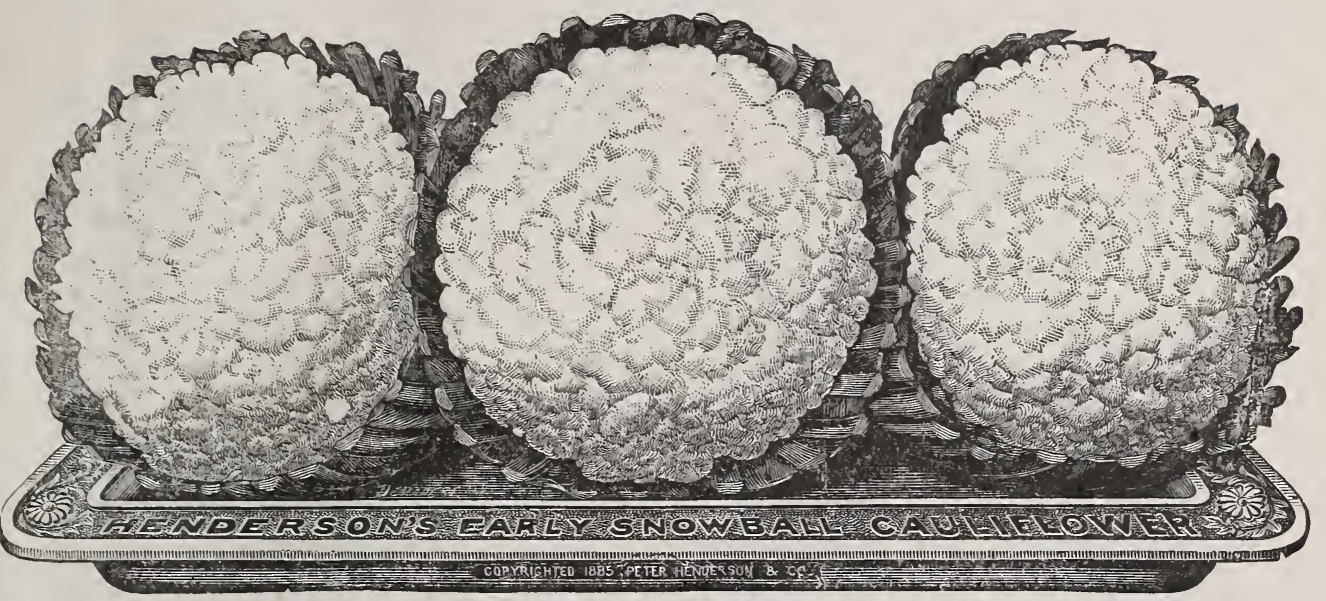

EARLY SNOWBALL CAULIFLOWER-The earliest. The surest header. The most profitable. The best variety for either the market or the family garden. Early Snowball Cauliflower is superior to all others: FIRST-Because it is earliest of all cauliflowers, has been conclusively shown season after season. Second-Because under the condition of an ordinary favorable season, nearly every plant will form a perfect

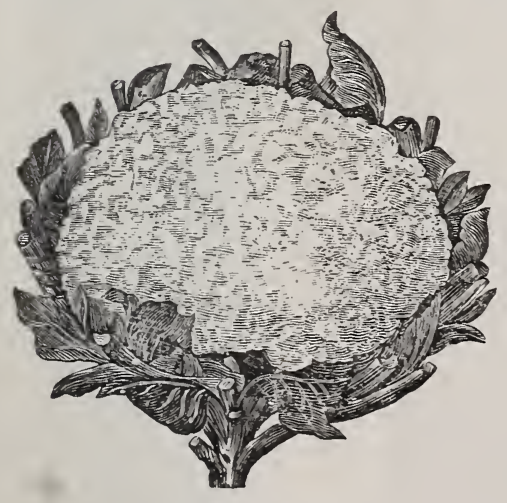

Autumn Giant. snow white head. THIRD-For the reason that its growing, compact habit enables one-third more to be planted on the same space of ground than can be done with any other variety. It does equally well for late planting. Price: package, $25 c ; 1 / 4$ oz. $75 c ;$ oz. $\$ 2.50$.

EXTRA EARLY DWARF ERFURT-First quality extra early; dwarf variety: compact growth: short outside leaves. Quarter ounce 75c; one ounce $\$ 2.00$.

ALTUMN GIANT-A large late cauliflower producing compact white head; should be planted rather early in order to produce heads before severe cold weather as the plants grow to a very large size before forming heads; oz. 60c: $1 / 4$ tb. $\$ 2.00$.

We Deliver at Your Station, Garden and Flower Seeds Except Peas, Beans and Corn. 


\section{CELERY}

Sow seed in hot bed; transplant four inches apart when three inches high, in finely pulverized soil; water and protect until well rooted, then transplant into rows of five or six feet apart, either on surface or well manured trenches a foot in depth; set the plants from six to eight inches apart; to blanch, draw earth around the plants from time to time, taking care not to cover top of center shoots.

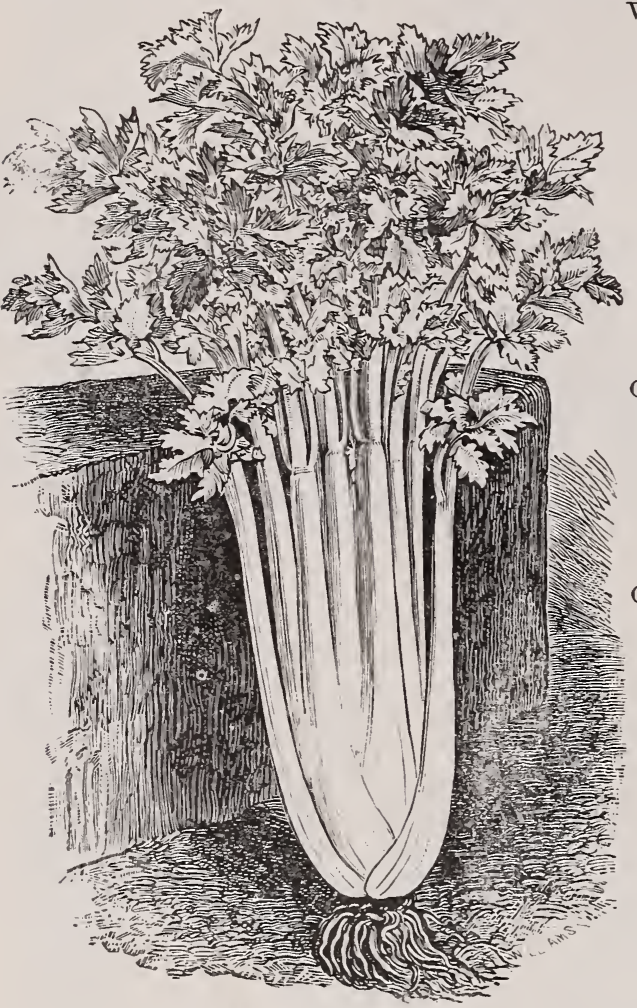

White Plume Celery.

WHITE PLUME CELERY-The earliest. handsomest and easiest grown, and undoubtedly the earliest celery grown in Colorado. The peculiarity of this variety is that its stock and portions of its inner leaves are white, so that by closing its stalks, either by tying them up with matting or by simply drawing the soil up against the plant and pressing it together with the hands, and again drawing up the soil with the hoe or plow, so as to keep the soil that has been squeezed against the celery in its place the work of blanching is completed Ounce 20c; $1 / 4$ tb. $60 \mathrm{c}$; to. $\$ 2.00$.

GOLDEN SELF-BLANCHING-Similar to the White Plume in its self-blanching characteristics; very solid and of a rich nutty flavor; plants of a yellowish green color, as they mature the inner stems and leaves turn a beautiful yellow. Grown for both early and late use; oz $35 \mathrm{c} ; 1 / 4$ Ib. $\$ 1.00 ;$ to. $\$ 3.50$.

GOLDEN HEART-A very solid variety; in size and habit of growth very much like Half Dwarf; has a rich nutty flavor: when blanched it is a yellowish white: oz. $20 \mathrm{c}: 1 / 4$ Ib. $50 \mathrm{c}$.

NEW SNOW WHITE-(Livingston's)-The Snow White is a pure white self-blanching variety. It is without a rival in purity and color. In vigor of growth, ease of blanching, size, richness of flavor, crispness and purity, it is ideal. It grows solid on all kinds of soil and keeps better than standard varieties; packet $10 \mathrm{c}$; oz. $35 \mathrm{c}$.

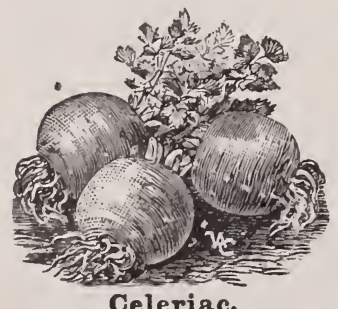

GIANT PASCAL - Late; very large ribbed celery; superior keeping quality; blanches very easily and quickly; the heart is golden yellow; the stalks are large, thick and solid; oz. $20 \mathrm{c} ; 1 / 4$ Ib. $50 \mathrm{c}$.

LARGE PRAIGUE CELERIAC or Turnip Rooted-The root of which is turnip shaped; is cooked or sliced and used with vinegar; more hardy than celery; oz. 20c.

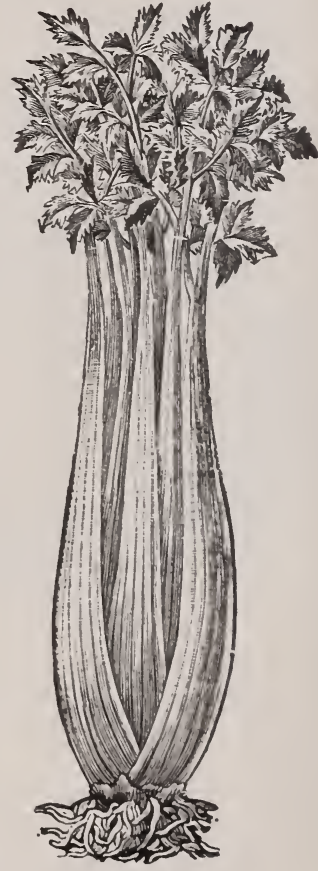

We prepay postage on all seeds except where noted otherwise. 


\section{CORN---Short Crop}

Drop in hills three feet apart and leave four plants to the hill. Plant at intervals from early spring to mid-summer.

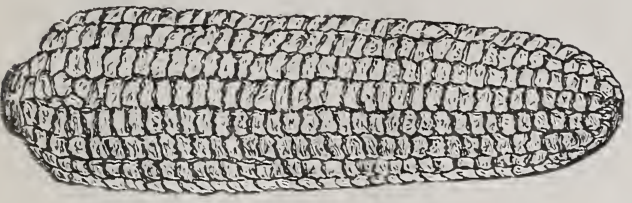

EXTRA EARLY ADAMS-The earliest white corn; small ears; 1b. 10c; 100 Ibs. $\$ 8.00$.

EARLY ADAMS-A very early market variety; ears good size, but short; tb. 10c; 100 ibs. $\$ 8.00$.

WHITE COB CORY - (New) - The earliest sweet corn grown; ears of fair size; very sweet; it matures for table use in 52 days; try it; 1b. $15 \mathrm{c}$.

KENDEL'S EARLY GIANT-Very early, ears large, kernels pure white; sweet and tender; 1b. $15 \mathrm{c} ; 100$ ibs. $\$ 12.50$.

EARLY MINNESOTA-A very early variety; quick growth; medium size cob; ib. 15c; 100 fbs. $\$ 10.00$.

STOWELL'S EVERGREEN-Hardy and productive; very tender and sugary; remaining a long time in condition for boiling; our strain is the best; 1b. $15 \mathrm{c} ; 100$ ibs. $\$ 12.50$.

BLACK MEXICAN-Seed black; a very sweet, tender variety, and considered the most sugary of all; tb. $15 \mathrm{c}$.

COUNTRY GENTLEMAN-A new sweet corn; medium early; very productive; small cob; kernel shoe-peg shape; retains its delicate tenderness and flavor even when a little old; Ib. $15 \mathrm{c}$; 100 tbs. $\$ 12.50$.

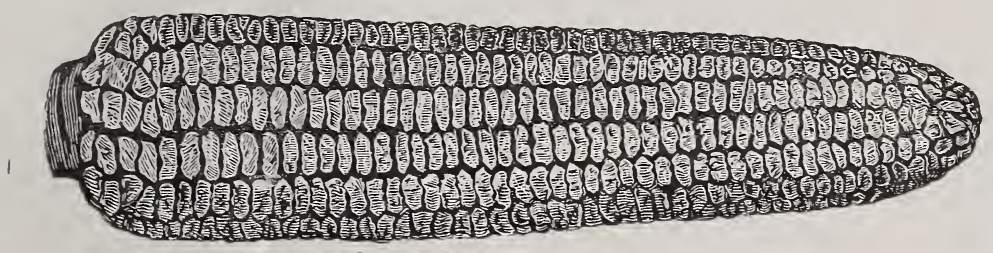

\section{Stowell's Evergreen.}

CORN SALAD.

BROAD LEAVED-Ounce $10 \mathrm{c} ; 1 / 4$ Ib. $25 \mathrm{c}$.

\section{CHICORY}

LARGE ROOTED-The leaves are used for salads; the dried roots of this variety are used as a substitute for coffee; oz. 15c: $1 / 4$ tb. $50 \mathrm{c}$.

\section{CRESS---OR PEPPER GRASS}

A well known pungent salad. Requires to be sown thickly and covered lightly at frequent intervals to keep up a succession, as it runs to seed.

EXTRA CURLED-Very finé; may be cut two or three times; oz. 10c; 1/4 Ib. 20c; 1b. 60c.

\section{CRESS---WATER}

This is a well known, hardy, perennial, aquatic plant, grown along the margin of running streams, ditches and ponds. Sow along water edge and when once started will increase by spreading of roots and seeding. It has a pleasant pungent taste; used mostly for greens. Ounce $50 \mathrm{c} ; 1 / 4 \mathrm{ib}$. $\$ 1.50$.

We are Here to Stay; We Want Your Trade. 


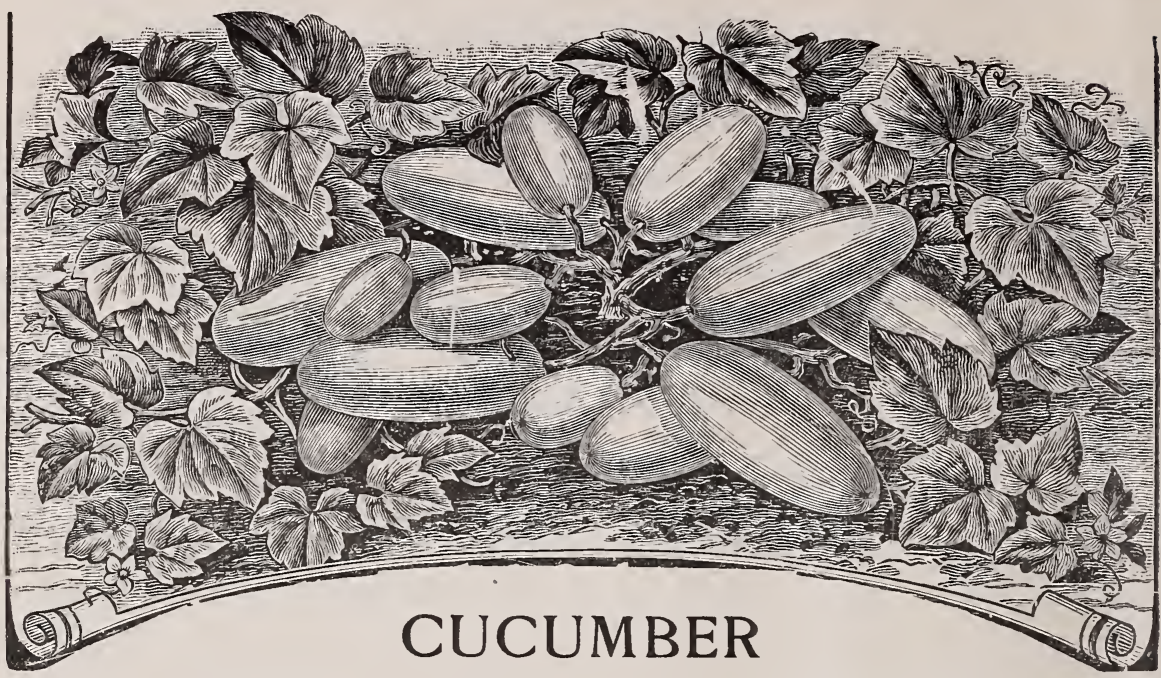

Drop in hill four to six feet apart; as soon as the weather becomes settled and warm: scatter eight or ten seeds to the hill; cover half an inch deep; pat down with a hoe.

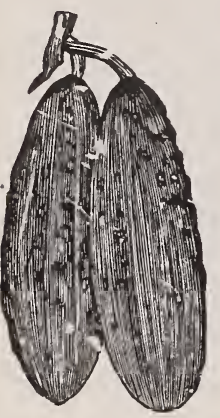

EARLY RUSSIAN-Earliest of all varieties; grows about four inches long; oz. $10 \mathrm{c}$; $1 / 4$ tb. $30 \mathrm{c}$; 1b. $\$ 1.00$.

NICHOLS' MEDIUM GREEN-(Pickling)-Is exceedingly productive and of medium size; also straight and smooth; one of the best for pickles; oz. $10 \mathrm{c} ; 1 / 4$ tb. $30 \mathrm{c}$; tb. $\$ 1.00$.

GREEN PROLIFIC-(Pickling)-As a pickling variety is unsurpassed: its characteristies are uniform growth, hardy, ever producing cucumbers not too large for pickling; very productive; $0 \mathrm{z} .10 \mathrm{c}$ : $1 / 4$ Ib. 30c: 1b. $\$ 1.00$.

LONG GREEN-Old standard variety; firm and crisp; for general family use there is no better; oz. $10 \mathrm{c} ; 1 / 4$ tb. $30 \mathrm{c}$; tb. $\$ 1.00$.

IMPROVED WHITE SPINE-An improved variety of White Spine; good for forcing and outdoor cultivation; very prolific; oz. 10c: $1 / 4$ Ib. $30 \mathrm{c}$ : 1b. $\$ 1.00$.

EARLY FRAME-Early sort of medium size; straight and handsome; oz. 10c; 1/4 1b. $30 \mathrm{c}$ : Tb. $\$ 1.00$.

BOSTON PICKLING-(Pickling)-A very productive kind of superior quality; largely grown by market gardeners about Boston; oz. 10c; 1/4 1b. $30 \mathrm{c}$; Ib. $\$ 1.00$.

CHICAGO PICKLING-(Pickling)-This is a variety that is taking well among the gardeners who have grown them for pickling cucumbers; very prolific and for small pickles, one of the best; oz. 10c; 1/4 Ib. 30c: Ib. $\$ 1.00$.

JAPANESE CLIMBING CUCUMBERS-This new cucumber is a strong and vigorous grower: the young plants are bushy; when established may be grown on fence or

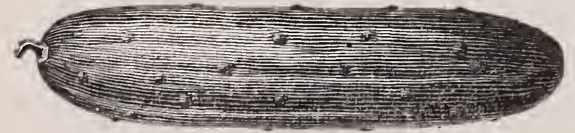
trellis, thus saving space in small gardens; the fruit is from ten to twelve inches long, of a fine green color; solid: fine for pickling as well as slicing; package $5 \mathrm{c}$; oz. $2 \mathrm{c}$. 


\section{EGG PLANT}

Sow in hot beds very early in spring and transplant to two or three feet apart in rich, warm soil.

NEW YORK IMPROVED PURPLE - The best variety in cultivation; early; a sure cropper and of a fine quality: $1 / 4 \mathrm{oz} .10 \mathrm{c}$; $1 / 2$ oz. $20 \mathrm{c} ;$ Oz. $40 \mathrm{c}$.

BLACK PEKIN-Fruit jet black; round and very solid; quite early, and a very fine variety; $1 / 4$ oz. $10 \mathrm{c} ; 1 / 2$ oz. $20 \mathrm{c} ;$ oz. $40 \mathrm{c}$.

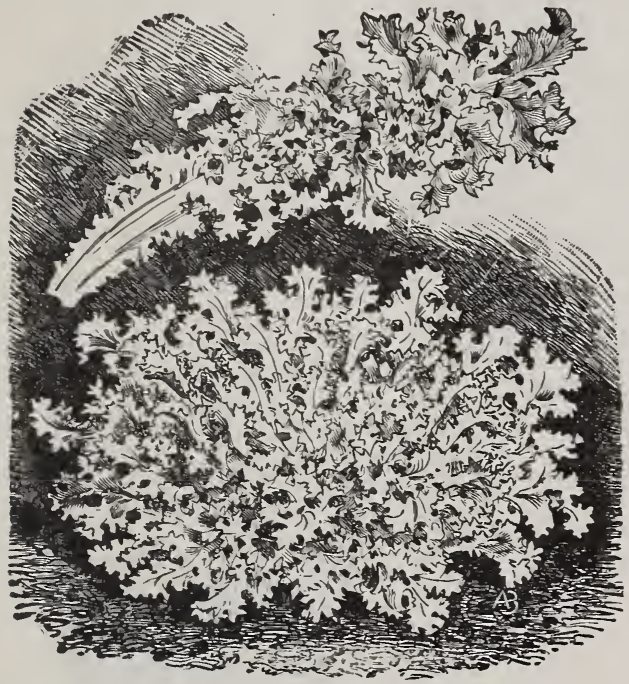

Endive.

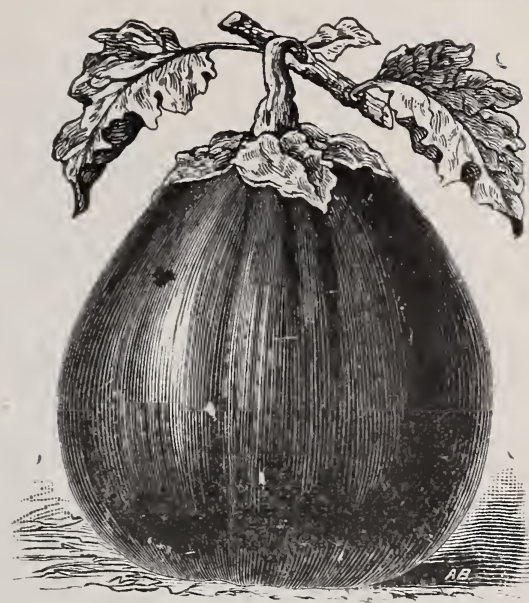

\section{ENDIVE}

GREEN CURLED-Not only useful as a salad, but is highly ornamental from its delicate cut and colored leaves; it is much used for garnishing; oz. $15 \mathrm{c}$; $1 / 4$ tb. $40 \mathrm{c}$; 1b. $\$ 1.50$.

BROAD LEAVED BATAVIAN-Chiefly used in soups and stews; required to be tied up for blanching; oz. $15 \mathrm{c}$; $1 / 4$ tb. $40 \mathrm{c}$; to. $\$ 1.50$.

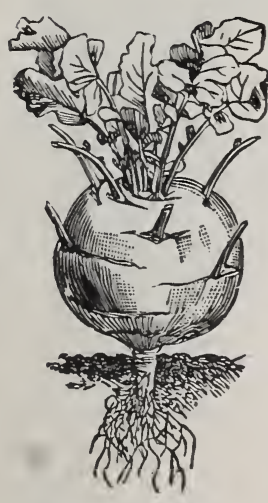

Kohl Rabi.

\section{KOHL RABI}

A vegetable intermediate between the cabbage and the turnip. Cultivate same as cabbage.

EARLY WHITE VIENNA-Is a greenish white outside; flesh white and tender while young; the best condition for use is when the roots are three or four inches in diameter; oz. $20 \mathrm{c} ; 1 / 4$ lb. $75 \mathrm{c}$.

\section{KALE}

Sow and cultivate same as cabbage.

DWARF GREEN-A popular variety; very hardy: improved by frost: oz. 15c: $1 / 4$ tb. $50 \mathrm{c}$.

\section{LEEK}

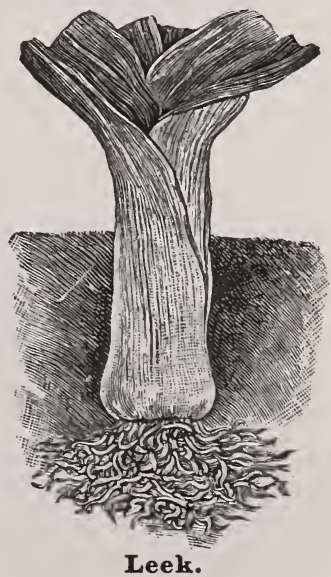

Leek.

LARGE ROUEN-A large and excellent variety. Price: oz. 15c; 1/4 Ib. 50c; ib. $\$ 1.75$. AMERICAN FLAG-A favorite market variety. Price: oz. 15c; 1/4 ib. 50c; ib. $\$ 1.75$. 


\section{LETTUCE}

Sow in rows about twelve inches apart, thin to eight or ten inches if you wish it to head. The more rapid the growth, the better the quality.

GRAND RAPIDS-This is a new forcing variety, originating near Grand Rapids, Mich., and it has proved in this vicinity the very best ever grown under glass; 1t is handsome in appearance; a very strong grower, not as liable to rot as the black seeded Simpson; it will keep from wilting after cutting longer than any other variety, thus making it a good shipper; oz. $10 \mathrm{c} ; 1 / 41 \mathrm{~b} . .25 \mathrm{c} ; 1 \mathrm{~b} .80 \mathrm{c}$.

EARLY TENNIS BALL-(Black Seed)-A medium sized head lettuce, very solid and crisp, the inner leaves a rich, creamy white; oz. $10 \mathrm{c} ; 1 / 41 \mathrm{~b} .25 \mathrm{c} ; 1 \mathrm{~b} .80 \mathrm{c}$.

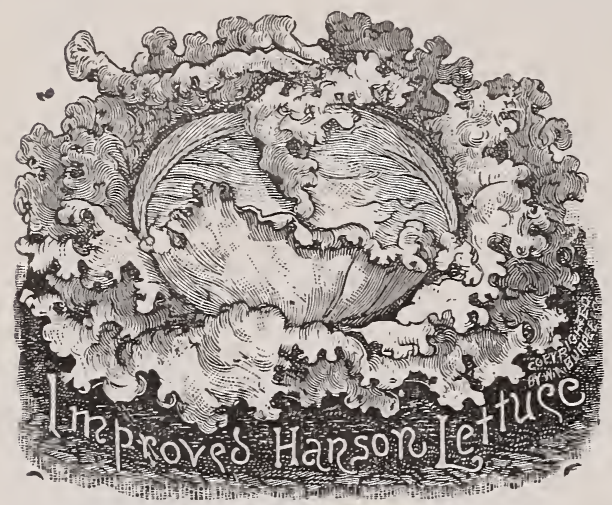

PRIZE HEAD-A fine variety; forms mammoth heads; very hardy; good for home use; the color is rich brown; very tender; oz. 10c; $1 / 4 \mathrm{lb}$. $25 \mathrm{c} ; 1 \mathrm{~b} .80 \mathrm{c}$.

HANSON-Heads very large, solid, tender and crisp, and of fine flavor; free from bitter taste; light green, almost white; oz. 10c; $1 / 4$ lb. 25c; 1b. $80 \mathrm{c}$.

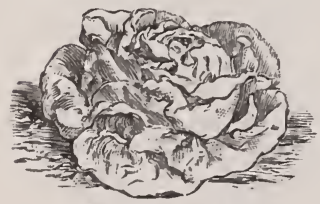

Tennis Ball.
BLACK SEEDED SIMPSON-One of the very best that is grown; used extensively for forcing under glass; a light green; a standard among the market gardeners; oz. $10 \mathrm{c}$; $1 / 4$ lb. $25 \mathrm{c}$; 1b. $80 \mathrm{c}$.

BOSTON CURLED-A variety of great beauty and superior quality; oz. 10c; 1/4 lb. $25 \mathrm{c}$; 1 b. $80 \mathrm{c}$.

DENVER MARKET-An early variety of head lettuce, used extensively for forcing, but does equally well in open ground; it forms large solid heads of light green color, very crisp and tender; is slow to go to seed; a distinct Colorado variety; oz. $10 \mathrm{c}$; $1 / 4$ lb. $25 \mathrm{c}$; 1b. $80 \mathrm{c}$.

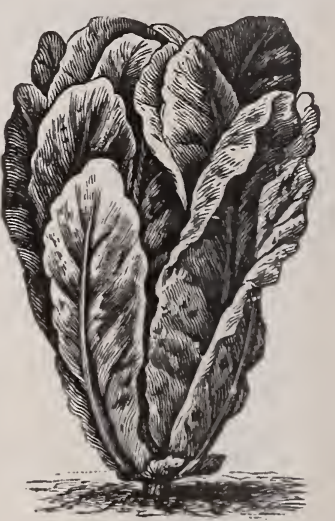

Cos Lettuce.
PARIS COS.-(Self Closing)-The Cos. lettuces are quite distinct, and are popular on account of their tender crisp leaves and delicious flavor. The leaves are long and narrow, and need to be tied up to bleach white. $1 / 2 \mathrm{oz}$. 10c: oz. $20 \mathrm{c}$. 


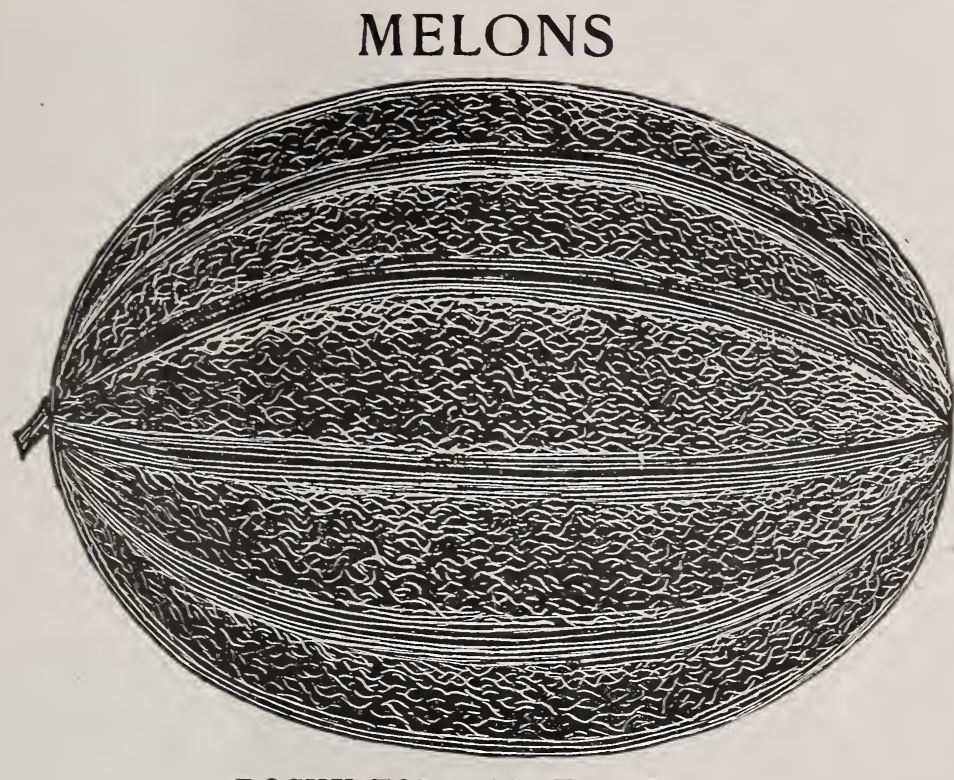

ROCKY FORD CANTALOUPE.

\section{NUTMEG SHAPE.}

GREEN FLESH.

This variety of cantaloupe has been better advertised than any other melon grown. The demand for the seed has been so great that a great many have been selling seed saved from late and inferior melons at a price agreeable to purchaser. The seed we offer is not the cheap seed but the very best. Give our seed a trial. It requires the very best of melon soil; is very productive, one acre having produced as high as 300 crates of marketable melons (45 melons to crate). Our stock of this variety is of the best strain and selection. When our present stock is exhausted, we will fill no more orders. Price: oz. $15 \mathrm{c} ; 1 / 4$ tb. $35 \mathrm{c}$; th. $\$ 1.00$, postpaid.

Beware of Cheap Seed of this Variety.

\section{ROCKY FORD WATERMELON.}

One of the very best melons for home and nearby markets. When known it is taken in preference to all others. It is an oblong melon of good size, green skin, bright red flesh and white seeds. We have the very best seed of this variety. Price: oz. 10c; $1 / 4$ lb. $30 \mathrm{c}$; 1b. $\$ 1.00$ postpaid.

\section{KLECKLEY'S SWEET WATERMELON}

This is without doubt one of the very best melons of recent introduction. Shaped very much like the Rocky Ford, but a larger melon; the skin is a very dark green; flesh bright red; rind very thin and hard, making it a good shipper. A fine grained melon and solid to the core. Price: oz. $10 \mathrm{c} ; 1 / 4$ tb. $30 \mathrm{c}$; tb. $\$ 1.00$, postpaid.

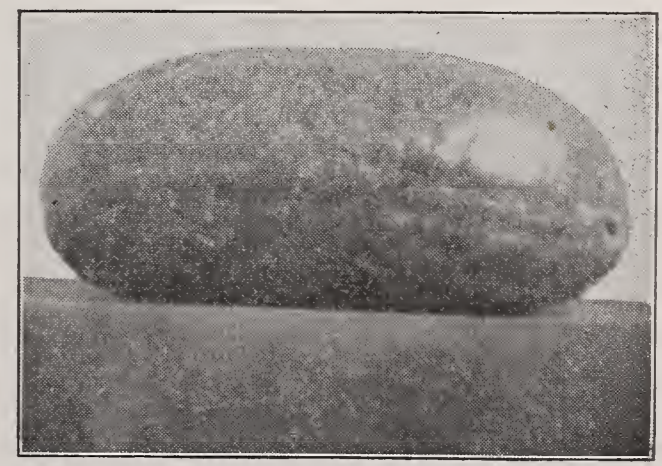

Kleckley's Sweet.

Special Prices to Market Gardeners in Large Orders. 


\section{MELONS--Continued}

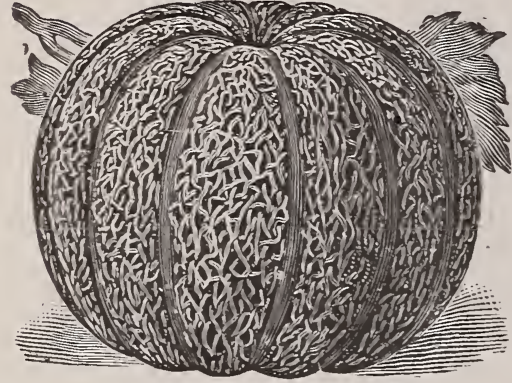

Washington Market.

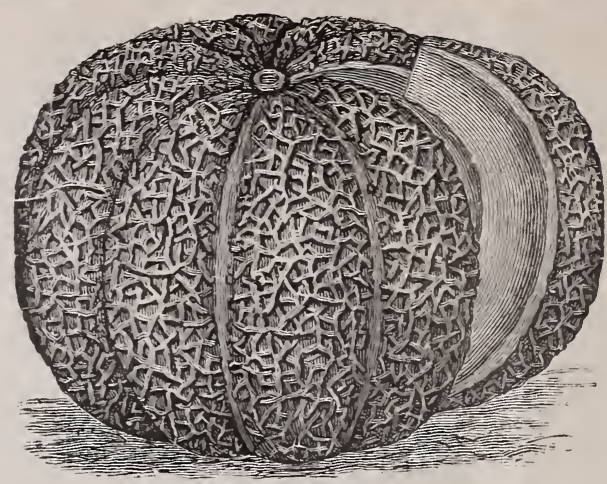

Extra Early Hackensack.

MELONS-Musk.

Want warm, light soil. Drop a dozen seeds in hills five or six feet apart. Thin to three or four plants to a hill, when out of danger from insects.

GRAND RAPIDS EARLY MARKET-A large handsome melon, two weeks earlier than any other variety; the flesh is yellow, clear to the rind; it grows two shapes, oblong and round; skin finely netted; of good size; oz. 10c; 1/4 1b. 25c; 1b. 60c.

EXTRA EARLY HACKENSACK-Claimed to be ten days earlier than the well known Hackensack, which it much resembles in shape and quality; oz. $10 \mathrm{c} ; 1 / 41 \mathrm{~b} .30 \mathrm{c} ; 1 \mathrm{~b} . \$ 1.00$.

MONTREAL-Round; densely netted, green skin; leads in size all nutmegs; oz. 10c; $1 / 4$ lb. $25 \mathrm{c} ; 1 \mathrm{~b} .60 \mathrm{c}$.

NETTED GEM-One of the earliest, best and most prolific small melons grown; they are globe-shaped, uniform in size; the flesh is light green and of very fine flavor; oz. $10 \mathrm{c} ; 1 / 4$ lb. $20 \mathrm{c} ; 1 \mathrm{~b} .60 \mathrm{c}$.

GREEN CITRON-Medium size; retted; flesh green; very thick; oz. 10c; 1/4 1b. 20c; 1b. 60c.

WASHINGTON MARKET-A. fine nutmeg melon, well netted; of fair size; uniform growth; one of the very best selling melons grown in this vicinity; second early; oz. $10 \mathrm{c} ; 1 / 4 \mathrm{lb} .30 \mathrm{c} ; 1 \mathrm{~b} . \$ 1.00$.

BAY VIEW-A large, prolific and fine flavored green fleshed melon; oz 10c; 1/4 1b. 20c; Ib. $60 \mathrm{c}$

BANANA-A long, slender variety, with salmon colored flesh; oz. 10c; 1/4 lb. 20c; lb. 60c.

PERFECTION OR PRINCESS-It is the finest and sweetest of all salmon or red flesh melons, nearly round, with heavily netted dark green skin; the flesh is of rich salmon color; sweet and luscious beyond description; it grows to large size, and in Colorado, is second early; oz. $10 \mathrm{c} ; 1 / 4 \mathrm{lb} .30 \mathrm{c} ; 1 \mathrm{~b} . \$ 1.00$.

\section{MELONS-Water.}

Plant same a.s Musk Melons; cover one inch deep.

DIXIE-This melon is earlier and more productive than Kolb's Gem; it is of a very fine appearance; dark color; beautifully striped; its eating qualities unexcelled, being sweet, juicy and tender, and not inclined to stringiness; we can recommend it to be one of the most productive and best shipping melons grown; oz. $10 \mathrm{c} ; 1 / 41 \mathrm{~b} .20 \mathrm{c}$; lb. $50 \mathrm{c}$.

ICE CREAM-Medium size; skin pale green; flesh solid; scarlet; crisp; delicious; oz. 10c: $1 / 4$ lb. 20c: 1 b. 50 c.

ICING OR ICE RIND-Oblong in shape; rind light green; seeds white; of good size and very proliflc; oz. $10 \mathrm{c} ; 1 / 4 \mathrm{lb} .20 \mathrm{c} ; 1 \mathrm{~b} .50 \mathrm{c}$.

DARK ICING-Oblong in shape; dark green; one of the earliest and best melons grown; oz. 10c: $1 / 4$ lb. $20 \mathrm{c}$; 1b. $50 \mathrm{c}$.

CUBAN QUEEN-A very large, light and green striped melon; solid; fine quality and a good sinipper; oz. $10 \mathrm{c} ; 1 / 4$ lb. $20 \mathrm{c} ; 1 \mathrm{~b} .50 \mathrm{c}$.

FLORIDA FAVORITE-Oblong in shape; growing to a very large size; rind with light green stripes; flesh light crimson; crisp and deliciously sweet; earlier than Kolb's Gem or Rattlesnake; oz. $10 \mathrm{c} ; 1 / 4$ ib. $25 \mathrm{c}$; ib. $75 \mathrm{c}$.

We prepay postage on all Garden and Flower seeds except Peas, Beans and Corn. 


\section{MELONS---Continued}

HUNGARIAN HONEY-The sweetest and most luscious melon grown; of medium size; almost a perfect globe in shape; the coloring is dark green with waterings of a darker green; the flesh is brilliant red and stringless; an early melon; thin skin; productive; oz. $10 \mathrm{c} ; 1 / 4$ lb. $25 \mathrm{c}$; lb. $75 \mathrm{c}$.

KOLB'S GEM-A large, oval shape melon; Kolb's Gem has proven to be the best melon for shipping; has been shipped hundreds of miles without any packing whatever; oz. $10 \mathrm{c} ; 1 / 4$ lb. $20 \mathrm{c}$; lb. $50 \mathrm{c}$.

GEORGIA RATTLESNAKE-A long large, light green striped, thin rind; flesh deep scarlet; solid; oz. 10c; $1 / 4$ lb. $20 \mathrm{c}$; lb. $50 \mathrm{c}$.

MOUNTAIN SWEET-Oblong variety; flesh scarlet; solid; very sweet; delicious; oz. $10 \mathrm{c} ; 1 / 4$ lb. $20 \mathrm{c}$; $1 \mathrm{~b}$. $50 \mathrm{c}$.
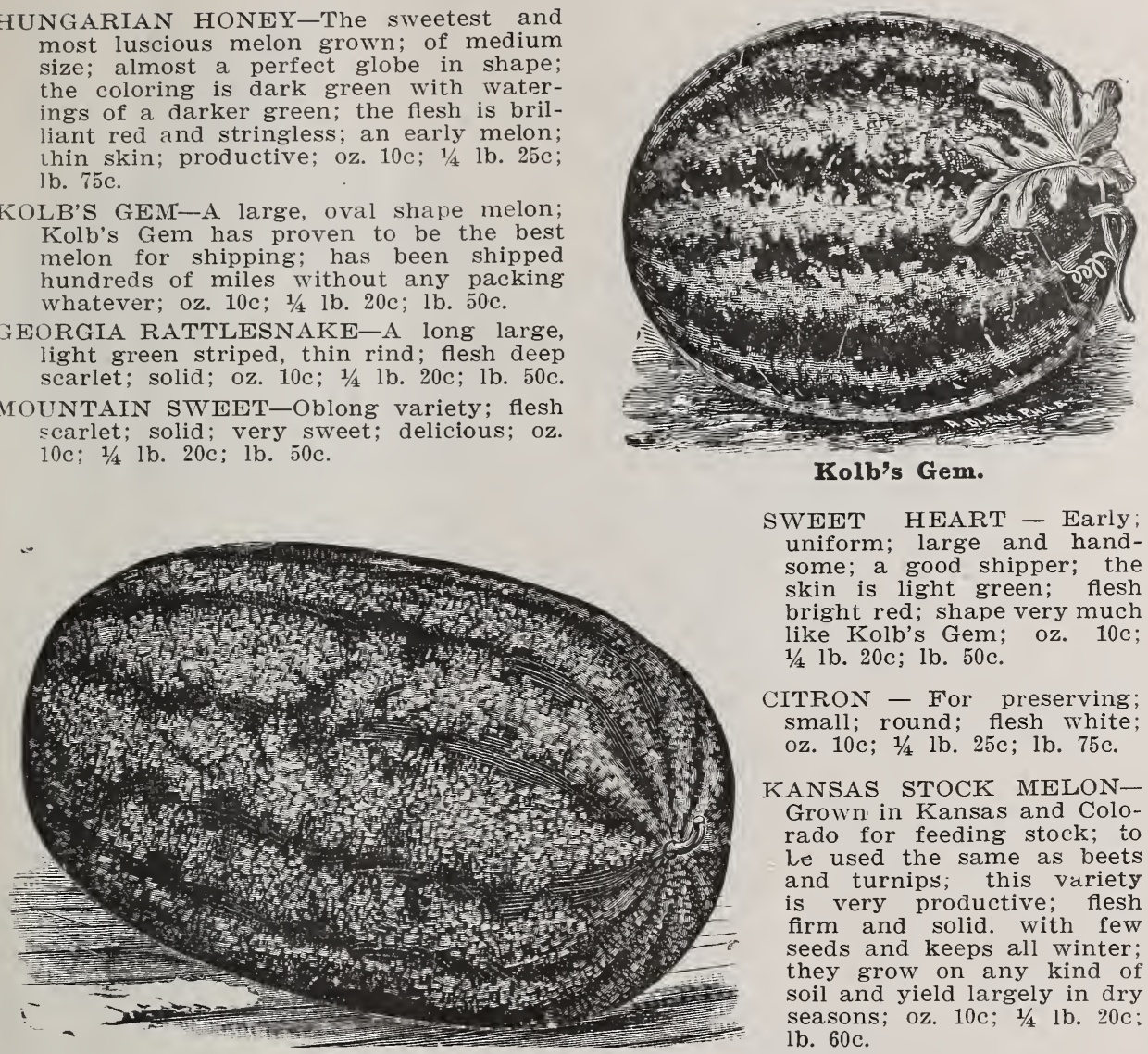

SWEET HEART - Early; uniform; large and handsome; a good shipper; the skin is light green; flesh bright red; shape very much like Kolb's Gem; oz. 10c; $1 / 4$ lb. $20 \mathrm{c}$; $1 \mathrm{~b}$. $50 \mathrm{c}$.

CITRON - For preserving; small; round; flesh white; oz. $10 \mathrm{c} ; 1 / 4$ lb. $25 \mathrm{c}$; $1 \mathrm{~b} .75 \mathrm{c}$.

KANSAS STOCK MELONGrown in Kansas and Colorado for feeding stock; to le used the same as beets and turnips; this variety is very productive; flesh firm and solid. with few seeds and keeps all winter; they grow on any kind of soil and yield largely in dry seasons; oz. $10 \mathrm{c}$; $1 / 4$ lb. $20 \mathrm{c}$ : lb. $60 \mathrm{c}$.

\section{MUSTARD}

Sow in drills one foot apart: cover half inch deep: used for salads.

WHITE ENGLISH-Excellent for greens; oz. $5 \mathrm{c} ; 1 / 41 \mathrm{~b} .15 \mathrm{c} ; 1 \mathrm{~b} .40 \mathrm{c}$.

BLACK OR BROWN SEED-Oz. 5c; $1 / 4$ 1b. 15c; 1b. $50 \mathrm{c}$.

SOUTHERN GIANT CURLED OR NEW CHINESE-Highly esteemed for salad. The leaves being double the size of the ordinary white mustard; stem more excellent and tender; sweet and pungent in flavor; oz. $10 \mathrm{c} ; 1 / 41 \mathrm{~b} .25 \mathrm{c} ; 1 \mathrm{~b} .75 \mathrm{c}$.

\section{OKRA}

Sow in rows two feet apart; thin plants to one foot; the pods are used in soup; being gathered when young.

DWARF GREEN-Early and very productive; pods smooth; oz. 10c; 1/4 lb. $25 \mathrm{c}$. WHITE VELVET-The pods are round and smooth and much larger than any other variety, and are very productive; oz. $10 \mathrm{c} ; 1 / 4$ lb. $25 \mathrm{c}$. 


\section{ONIONS}
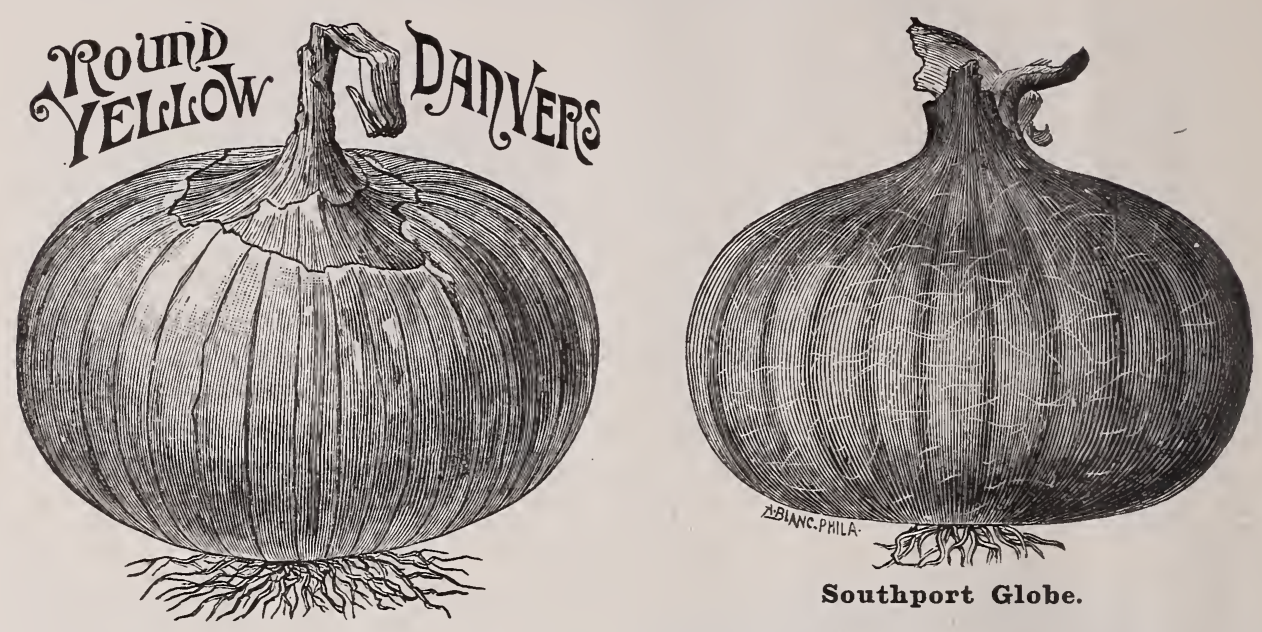

Southport Globe.

Thrive best in rather deep, rich, loamy soil, and succeed well when cultivated on the same ground for successive years. Plow not over five inches deep and work well with the cultivator; see that the ground is well pulverized; sow the seed in drills about fourteen inches apart; keep the surface of the ground open and free from weeds by frequent hoeing; do not stir the soil too deep, or collect it around the growing bulbs.

Special prices on Yellow Danvers, Yellow Globe Danvers and Prize Takers, in 5 and 10 pound lots.

EXTRA EARLY RED-Matures very early; medium size; deep red in color, and an excellent keeper: oz. 10c; 1/4 lb. 30c; 1b. $\$ 1.00$

RED WEATHERSFIELD-The old standard sort; large size, deep red, thick, approaching to round shape; fine grain and productive; oz. $10 \mathrm{c} ; 1 / 4$ Io. $30 \mathrm{c} ; \mathrm{ID} . \$ 1.00$.

NEAPOLITAN MARZAJOLA-A beautiful silvery white skinned variety; not a good keeper; very early; flat; oz: $20 \mathrm{c}$; $1 / 4$ lb. $50 \mathrm{c}$; lb. $\$ 1.75$.

AUSTRALIAN BROWN-This new onion has been thoroughly tried in this locality and proven the best early, long-keeping onion grown; the outside skin is a deep amber blown; extremely hard and firm; fine flavor; oz. 10c; 1/4 Ib. 30c; 1D. $90 \mathrm{c}$.

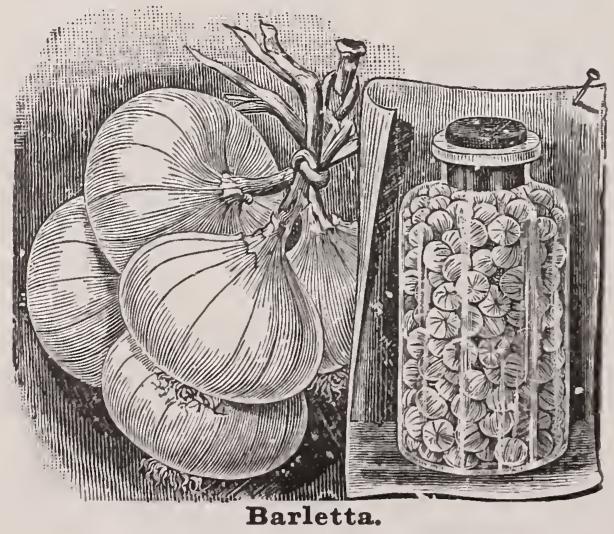

EARLY RED GLOBE-A handsome, red globular shaped onion and a good keeper; oz. 15c; $1 / 4$ lb. $50 \mathrm{c}$; 1b. $\$ 1.50$.

NEW QUEEN-One of the earliest; small; flat, white; some grow them for pickling; oz. $20 \mathrm{c}$; $1 / 4$ Ib. $60 \mathrm{c}$; to. $\$ 2.00$.

WHITE PORTUGAL OR SILVER SKIN -Large, flat, early variety; skin loose; mild flavor, not an extra good keeper; oz. $20 \mathrm{c}$; $1 / 4$ 1b. $50 \mathrm{c}$; 1b. $\$ 1.75$.

MAMMOTH SILVER KING-A large white or silver skin onion; very mild; a fine onion for immediate use, but not a good keeper; oz. 20c; $1 / 4$ lb. 60c; 1b. $\$ 2.00$.

BARLETTA-A very early, small, pure white lariety; flesh is firm and mild flavor; used almost exclusively for pickling; oz. $20 \mathrm{c}$; $1 / 4$ lb. $60 \mathrm{c}$; lb. $\$ 2.00$. 


\section{ONIONS---Continued}

YELLOW GLOBE DANVERS-This variety is without doubt the very best onion to grow for a main crop; they are good keepers, always salable, and have proved far more profitable than any other variety in this section; it is a globe shape, and for that reason it is far more productive than the flat varieties; oz. $10 \mathrm{c} ; 1 / 4 \mathrm{~b} .30 \mathrm{c} ; 1 \mathrm{~b} .90 \mathrm{c}$.

YELLOW DANVERS-Round; a good keeper; earlier than the Yellow Globe Danvers, making it a better variety for the foothills; very productive; oz. $10 \mathrm{c} ; 1 / 4 \mathrm{lb} .30 \mathrm{c} ; 1 \mathrm{~b} .90 \mathrm{c}$. SOUTHPORT WHITE GLOBE-Is a white, globe shaped onion, produces well; is a good seller; not so good a keeper as Danvers; oz. $20 \mathrm{c}$; $1 / 4$ tb. $60 \mathrm{c}$; tb. $\$ 2.00$.

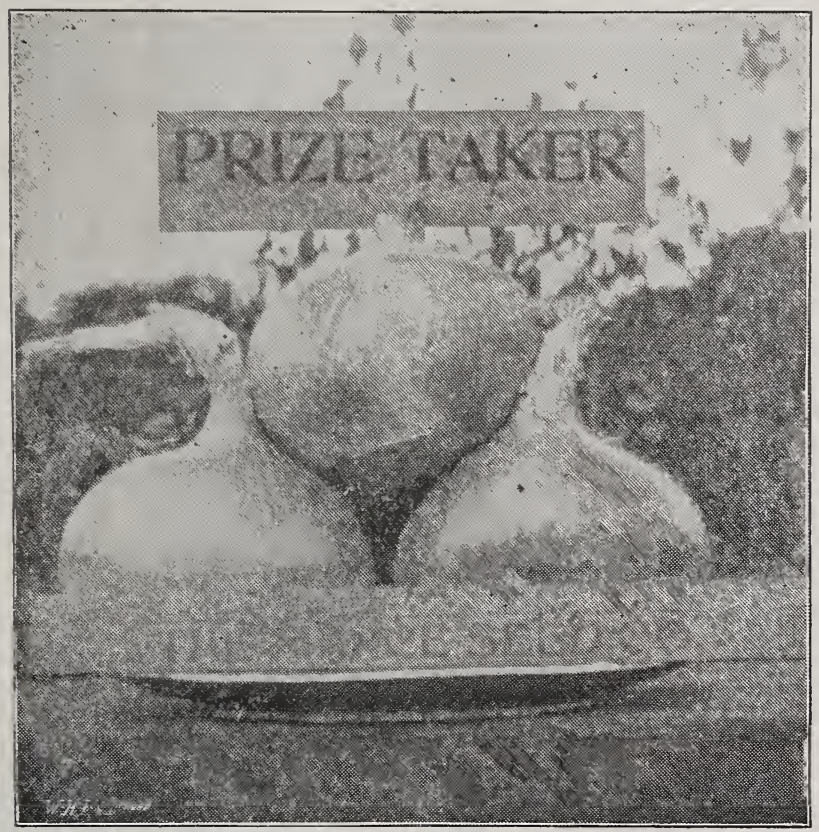

Prize Taker.
WHITE GLOBE - A large globe shaped onion; firm; fine grained; of mild flavor and commands the highest market price; oz. 20c; $1 / 4 \mathrm{Ib}$. 60 c; th. $\$ 2.00$.

PRIZE TAKER-OUT seed of this well established variety of onion is of the best. The adjoining picture is a production from a photograph taken from onions grown on the St. Charles Mesa by one of our market gardeners.

You will not miss it by growing our Prize Taker onion seed. They are straw color. very large and globe shaped. Oz. 15c; 1/4 lb. $40 \mathrm{c}$; lb. $\$ 1.25$.

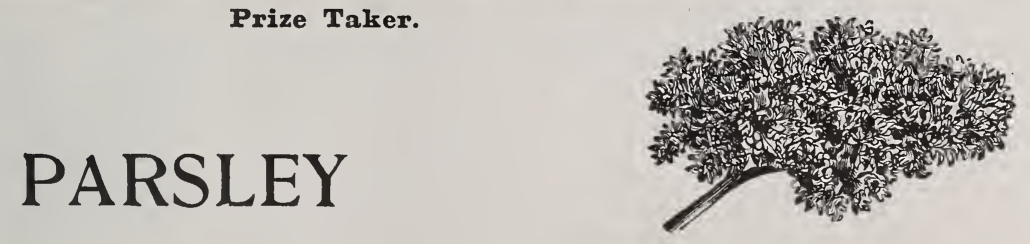

Sow early in spring, after soaking a few hours. Sow in rows one foot apart.

EXTRA CURLED-Finely curled variety; oz. $10 \mathrm{c} ; 1 / 4$ lb. $30 \mathrm{c}$.

CHAMPION MOSS-Curled; elegant for garnishing; oz. $10 \mathrm{c} ; 1 / 4$ lb. $30 \mathrm{c}$.

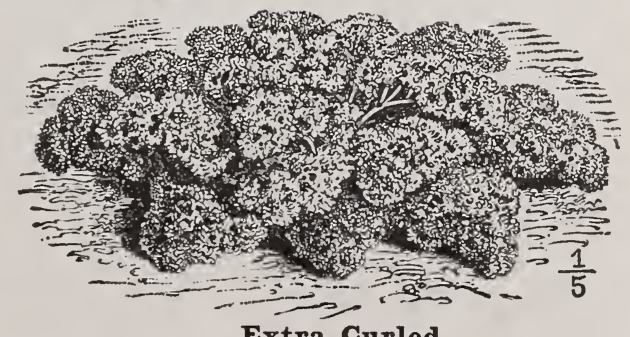

Extra Curled.

We prepay postage on all Garden and Flower seeds except Peas, Beans and Corn. 


\section{PEAS}

Crop short; when present stock is sold, we can fill no more orders at prices quoted. For early peas, sow as soon as the ground can be worked, in a warm place, manure the ground well, and plant in double rows about two or three freet apart; they should be kept clean, and earthed up twice during their growth.

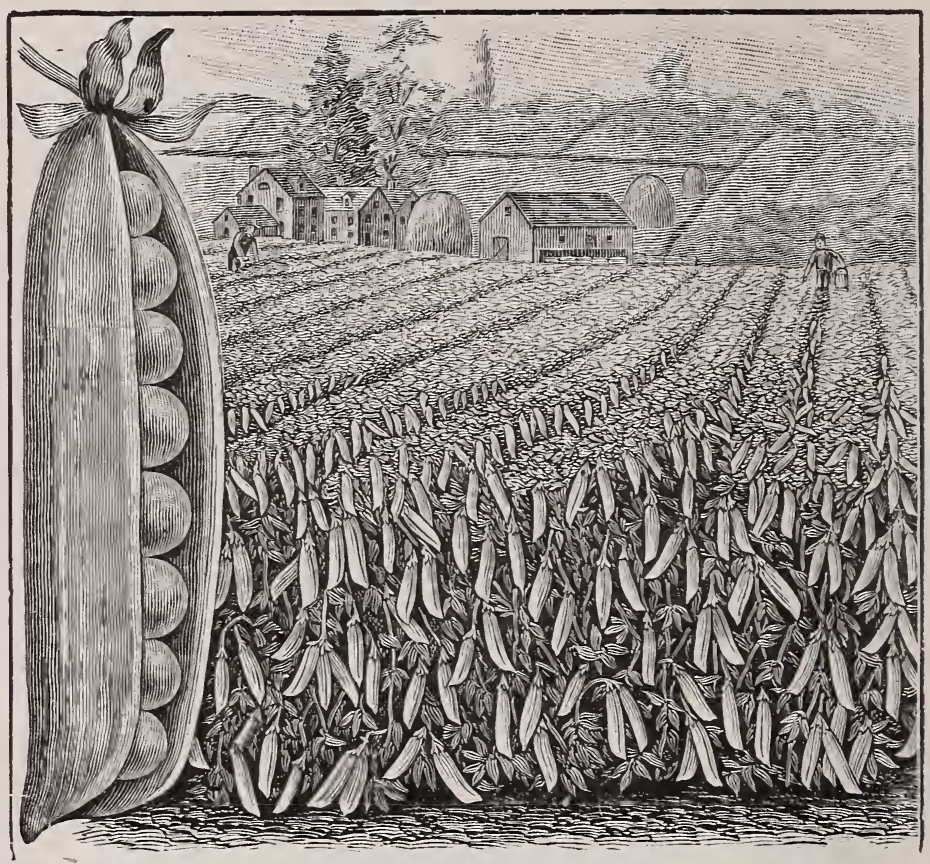

\section{Extra Early Varieties.}

ALASKA-Considered the earliest pea yet brought out; producing pod of good size and well filled, being just the thing for market gardeners: lb. $15 \mathrm{c} ; 100 \mathrm{lb} . \$ 10.00$.

NOTT'S EXCELSIOR-New-One of the very best early dwarf peas; it combines to a wonderful degree the good qualities of American Wonder, but the vines are larger and more vigorous; the peas in sweetness and quality are unsurpassed; a fine variety for market gardeners; 1b. 20c; cwt. $\$ 15.00$.

LAXTON'S ALPHA-The earliest of all the wrinkled varieties; of fine quality and very prolific; $1 \mathrm{~b} .20 \mathrm{c}$; cwt. $\$ 15.00$.

AMERICAN WONDER-One of the earliest wrinkled peas in cultivation; very productive and sweet; rich flavor; very compact and dwarf; 1b. $20 \mathrm{c}$; cwt. $\$ 15.00$.

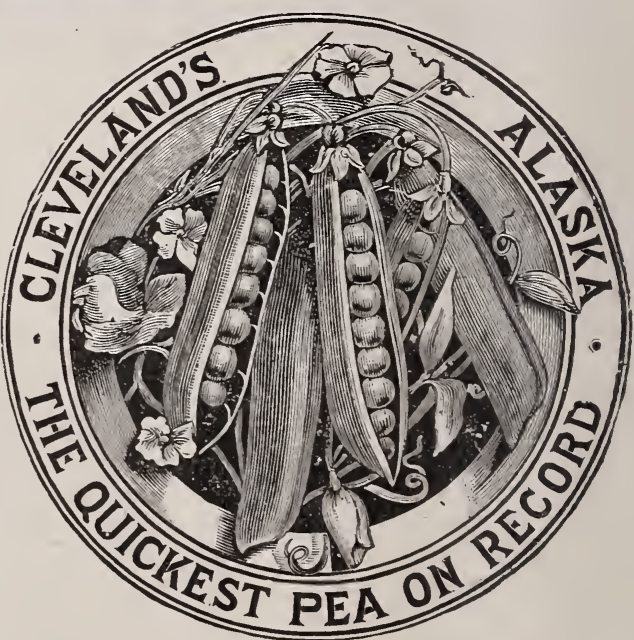

MCLEAN'S LITTLE GEM-A second early dwarf; very proific, wrinkled, and of a delicious flavor; $1 \mathrm{~b} .15 \mathrm{c}$; ewt. $\$ 12.50$.

Peas and Beans in 25-1b. Lots at 100-1b. Rates. By Mail 8c Ponnd Postage. 


\section{PEAS---Continued}

\section{Second Early and General Crop.}

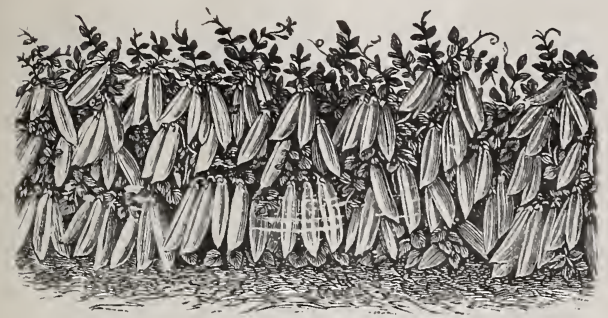

STRATAGEM-One of the very best second early varieties grown; a vigorous and branching vine; has very broad pods: very sweet and productive; height of vine about eighteen inches; 1b. $20 \mathrm{c}$; cwt. $\$ 15.00$.

CARTER'S PREMIUM GEM-A very productive pea; second early; good for market gardeners; lb. 20c; cwt. $\$ 15.00$.

TELEPHONE-Very productive and of the best quality; the vine is a strong grower. averaging eighteen pods to the stalk; pods large size and well filled with peas of fine flavor; height about four and onehalf feet; lb. 20c; cwt. $\$ 15.00$.

BLISS EVERBEARING-A large variety; vines grow from eighteen to twenty-four inches in height; foliage large, so should not be planted too thick for a continuance of bearing. This pea can not be excelled; lb. $15 \mathrm{c}$; cwt. $\$ 12.50$

CHAMPION OF ENGLAND-One of the best and most popular peas in cultivation. Tall; needs bushing; $1 \mathrm{~b} .15 \mathrm{c}$.

WHITE EYED MARROWFAT-A very fine, large pea, broad pods, well filled; hardy and productive; the very best for field culture; lb. 10 c; cwt. $\$ 6.00$.

DWARF FRENCH SUGAR-Edible Pods-Can be cooked in the pods or shelled; tb. 20c; cwt. $\$ 15.00$ :

CANADA FIELD-Used for field culture; when dry are excellent for feeding stock; market price.
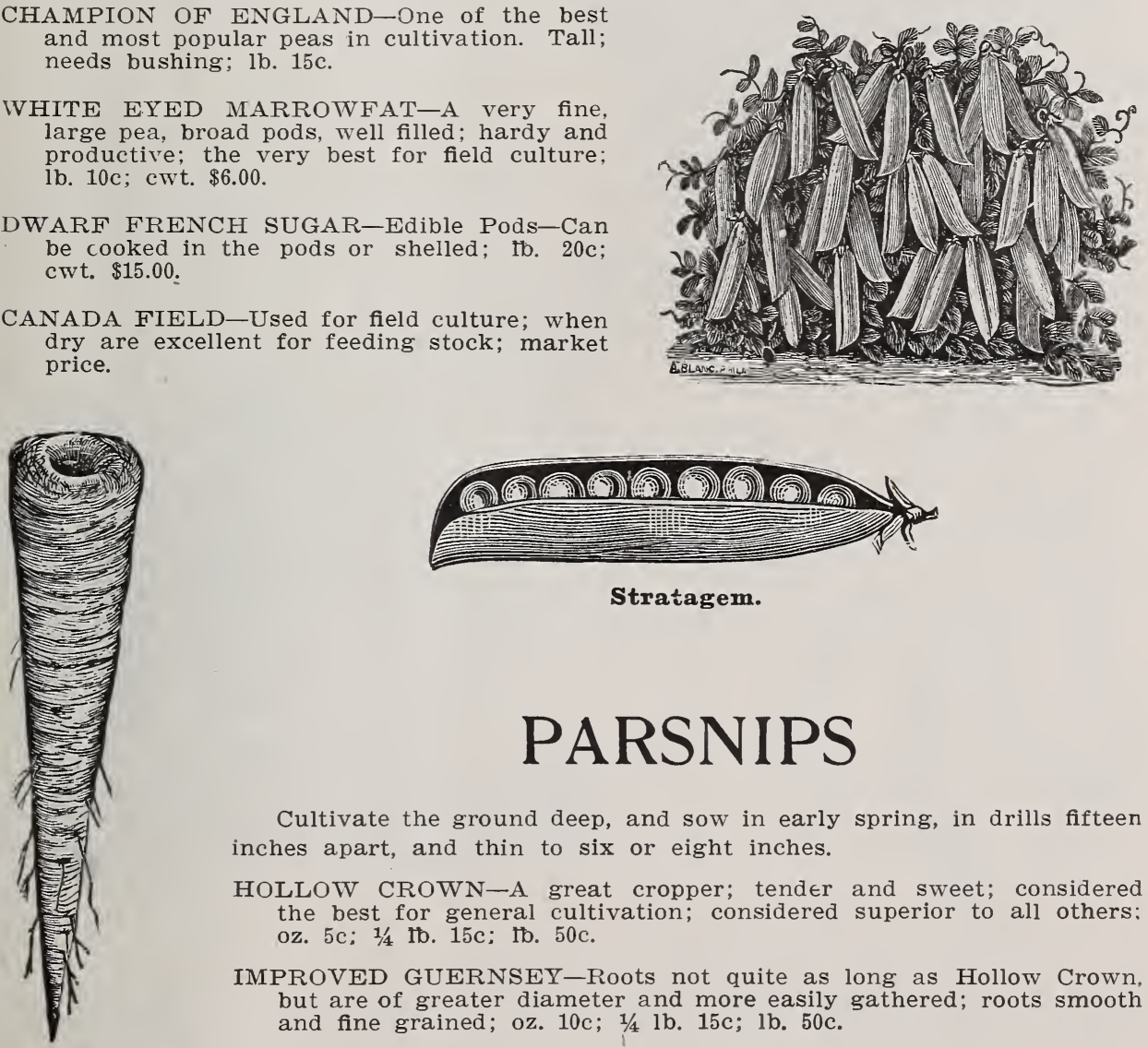

Stratagem.

\section{PARSNIPS}

Cultivate the ground deep, and sow in early spring, in drills fifteen inches apart, and thin to six or eight inches.

HOLLOW CROWN-A great cropper; tender and sweet; considered the best for general cultivation; considered superior to all others: oz. $5 \mathrm{c} ; 1 / 4 \mathrm{tb} .15 \mathrm{c} ; \mathrm{tb} .50 \mathrm{c}$.

IMPROVED GUERNSEY-Roots not quite as long as Hollow Crown, but are of greater diameter and more easily gathered; roots smooth and fine grained; oz. $10 \mathrm{c}$; 1/4 lb. 15c; lb. $50 \mathrm{c}$.

We are Here to Stay; We Want Your Trade. 


\section{PEPPERS}

Should be started in a cold frame or hot bed; transplant when three inches high, one foot apart in drills twenty inches apart; earth up a little in hoeing, which can be continued until the plants are in full bloom.

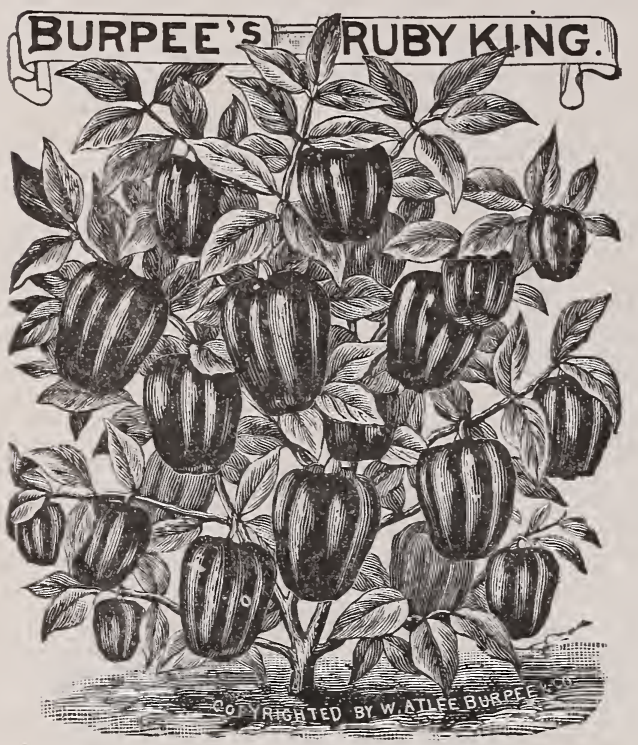

RUBY KING-Grows to a very large size; the fruits are six to seven inches long by five through; of a bright red color; very productive; mild and pleasant in flavor; $1 / 4$ oz. $10 \mathrm{c} ; 1 / 2 \mathrm{oz}$. $15 \mathrm{c} ; \mathrm{oz} .25 \mathrm{c}$.

CHILI-Very strong and prolific; $1 / 4 \mathrm{oz}$ $10 \mathrm{c} ; 1 / 2$ oz. $15 \mathrm{c}$; oz. $25 \mathrm{c}$.

CAYENNE-Long, red, hot and pungent; dwarf; $1 / 4$ oz. $10 \mathrm{c} ; 1 / 2$ oz. $15 \mathrm{c} ;$ oz. $25 \mathrm{c}$.

MAMMOTH GOLDEN QUEEN-NewThe largest, handsomest and most productive of all; it and the Ruby King are the largest and best peppers grown-one is a golden yellow and the other a bright red. Try it; $1 / 4$ oz. $10 \mathrm{c} ; 1 / 2$ oz. $15 \mathrm{c}$; oz. $25 \mathrm{c}$.

PROCOP'S GIANT-Very large, crisp and sharp pepper; average length six inches; a scarlet color; flesh very thick; $1 / 4$ oz. $10 \mathrm{c} ; 1 / 2$ oz. $15 \mathrm{c}$; oz. $25 \mathrm{c}$.

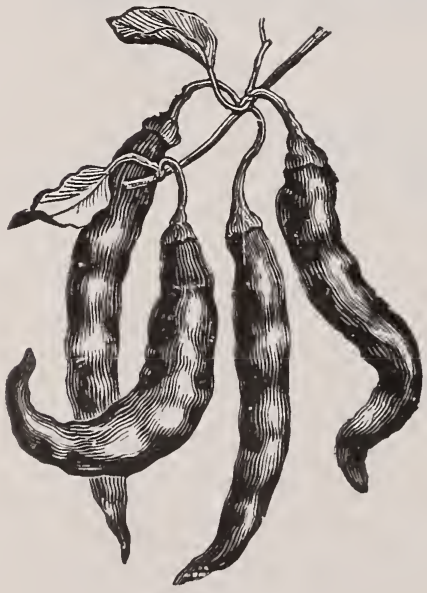

Cayenne.

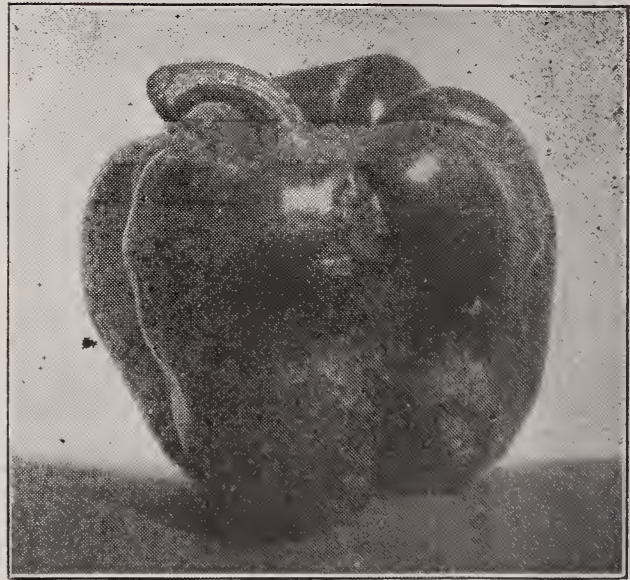

Chinese Giant.

NEW CHINESE GIANT RED IPEPPER-This is the largest and finest mild red pepper. It is early in ripening and very productive. The plants are vigorous in growth but of stocky habit, seldom growing more than two feet high. Price: $1 / 40 z .20 \mathrm{c} ; 1 / 2 \mathrm{oz}$ 40c: $0 \mathrm{z}, 60 \mathrm{c}$.

We prepay postage on all Garden and Flower seeds except Peas, Beans and Corn. 


\section{PUMPKIN}

Cultivate same as squash.

CONNECTICUT FIELD-Large yellow variety; hard shell; excellent for field culture; stock pumpkin; oz. $5 \mathrm{c} ; 1 / 4 \mathrm{tb}$. $10 \mathrm{c} ;$ tb. $30 \mathrm{c}$.

SUGAR-Smaller than Field, finer grained, sweeter; very prolific; fine for table use; oz. $10 \mathrm{c}$; $1 / 4 \mathrm{tb}$. $20 \mathrm{c}$; to. $75 \mathrm{c}$.

LARGE CHEESE-One of the best varieties for cooking; oz. $10 \mathrm{c}$; $1 / 4$ tb. $20 \mathrm{c}$; Ib. $75 \mathrm{c}$.

MAMMOTH-Grows to an enormous size; fine flavor; grown extensively for stock feed; oz. $15 \mathrm{c} ; 1 / 4$ Ib. $45 \mathrm{c}$; 1b. $\$ 1.50$.

CASHAW-Very productive and of good size; flesh yellow and solid; a good keeper; oz. $10 \mathrm{c}$; $1 / 4$ tb. $20 \mathrm{c}$; to. $60 \mathrm{c}$.

JAPANESE-Very popular pie pumpkin; Oz. $10 \mathrm{c} ; 1 / 4$ tb. $20 \mathrm{c}$; tb. $60 \mathrm{c}$.

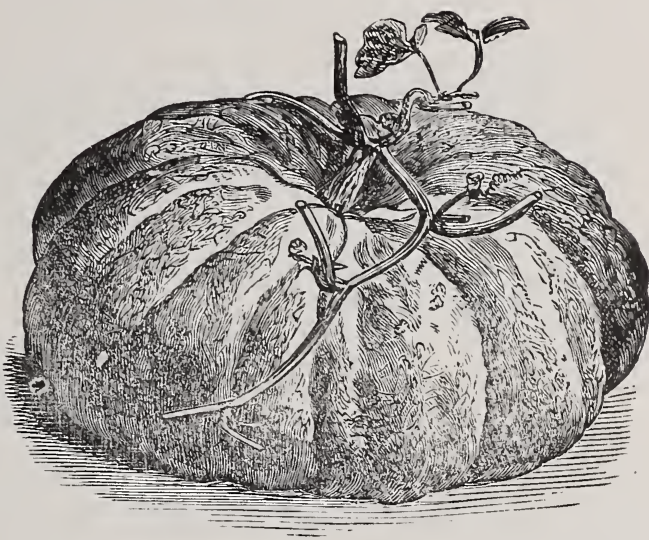

WINTER LUXURY OR LIVINGSTON'S PIE SQUASH-The color of the skin is similar to that of the Golden Russett apple; flesh yellow and very thick; medium sict; quite early and very productive; rapid and hardy grower; the finest for pies. price: Oz. 15c; $1 / 4$ tb. $40 \mathrm{c}$; Ib. $\$ 1.25$.
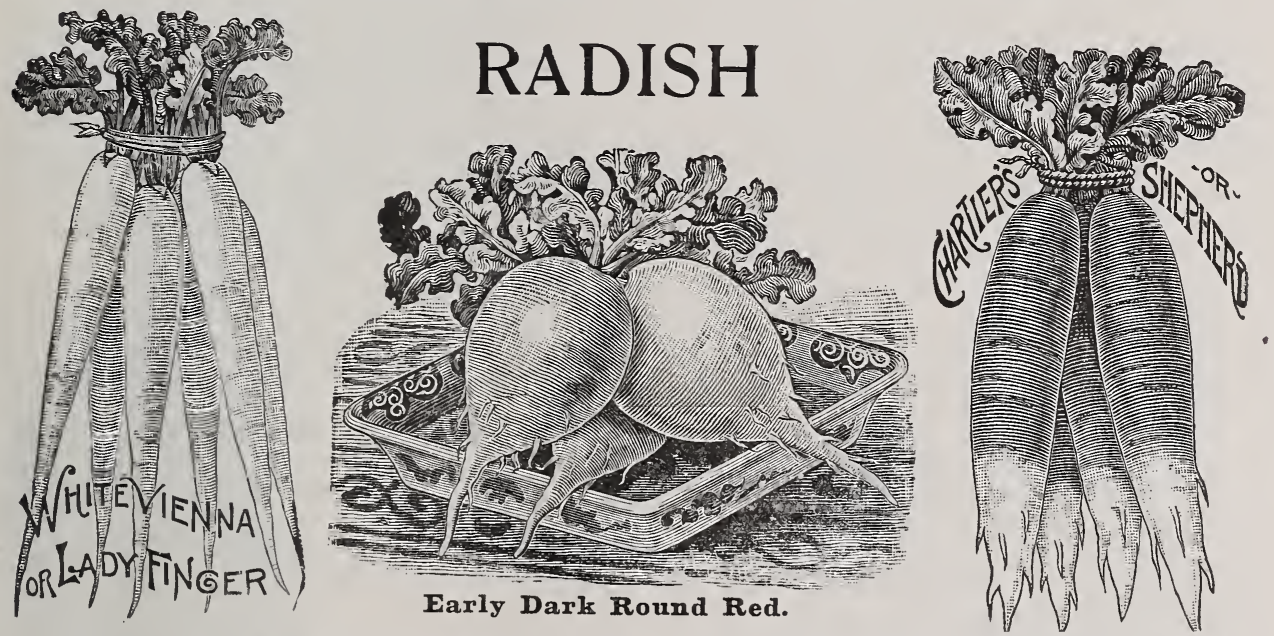

Soil for radishes should be light, rich and mellow, as their tender and mild qualities depend upon their rapid growth. Sow as early as the ground can be worked, at intervals of ten to twelve days for a succession. The winter varieties should be sown in August and lifted before frost and stored in the cellar.

EARLY LONG SCARLET SHORT TOP-This is the standard variety for market gardeners; grows about seven inches long, half out of the ground; is brittle and crisp; grows quick; bright scarlet color; tapers regularly to the root; is straight and smooth; oz. $10 \mathrm{c}$; $1 / 4$ Ib. $20 \mathrm{c}$; 1b. $60 \mathrm{c}$.

LONG WHITE VIENNA-This radish is the finest long white radish grown; skin and flesh are pure white; brittle, crisp and of a rapid growth; oz. $10 \mathrm{c} ; 1 / 4 \mathrm{Ib}$. $25 \mathrm{c} ; \mathrm{Ib} .60 \mathrm{c}$.

CINCINNATI MARKET-Grows straight and smooth, six to seven inches long. This radish has been grown by Cincinnati, Ohio, gardeners for the past thirty years and is considered far superior to Long Scarlet Short Top. It is an attractive scarlet color, skin is very thin, the flesh crisp, brittle and of delightful flavor. The finest long radish for forcing under glass. Oz. $10 \mathrm{c}$; $1 / 4$ ib. $20 \mathrm{c}$; 1b. $60 \mathrm{c}$.

We Prepay Postage, Except Where Noted, on Vegtable and Flower Seeds. . 


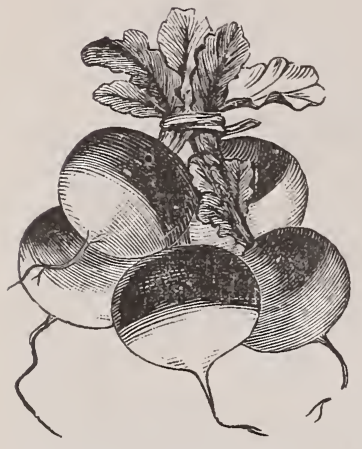

\section{RADISH---Continued}

EARLY SCARLET TURNIP-ForcingThe very best; oz. $10 \mathrm{c} ; 1 / 4$ 1b. $25 \mathrm{c}$; 1b. $75 \mathrm{c}$.

EARLY DARK ROUND RED-Very early, best round variety; skin dark red; flesh white: short top; very popular; oz. $10 \mathrm{c} ; 1 / 4$ 1b. $25 \mathrm{c}$; 1b. $60 \mathrm{c}$.

EARLY SCARLET TURNIP WHITE TIP-Same as Early Scarlet Turnip, but white at the tip, making it a showy variety; oz. 10c; $1 / 4$ to $25 \mathrm{c}$; 1b. $60 \mathrm{c}$.

RUSY GEM-One of the very earliest in cultivation; globe shape; rich, deep scarlet top, blending into pure white at bottom; good variety for forcing and general crop; oz. $10 \mathrm{c} ; 1 / 4$ tb $25 \mathrm{c}$; 1b. $60 \mathrm{c}$.

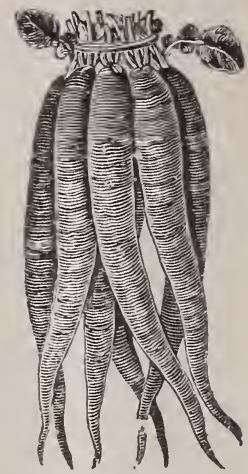

WOOD'S EARLY FRAME-Not quite as long as the Early Long Scarlet Short Top, but thicker; brilliant scarlet color, fine flavor and brittle; a very productive variety; oz. $10 \mathrm{c} ; 1 / 4$ 1b. $25 \mathrm{c}$; 1b. $60 \mathrm{c}$.

WHITE TURNIP-Early; in form like the Early Scarlet, but pure white; excellent flavor; oz. $10 \mathrm{c}$; $1 / 4$ tb. $25 \mathrm{c}$; tb. $60 \mathrm{c}$.

EARLY SCARLET TURNIP-A small, round, turnip shaped radish; grows quick; oz. 10c; $1 / 4$ th $25 \mathrm{c} ;$ it $60 \mathrm{c}$.

GIANT WHITE STUTTGART-An early and remarkably quick growing turnip shaped radish; the flesh and skin are pure white; crisp and fine flavor. Oz. 10c; 1/4 tb. 25c; 1b. $60 \mathrm{c}$.

IMPROVED CHARTIER OR SHEPHERD RADISH-Of quick growth; about two-thirds the length being crimson color, shaded off lighter until at the bottom they are white. We can recommend this radish to ve one of the best for continuous planting; oz. $10 \mathrm{c} ; 1 / 4 \mathrm{tb} .25 \mathrm{c}$; $1 \mathrm{~b} .60 \mathrm{c}$.

GOLDEN GLOBE-Rapid growth, globe shape; oz. 10c; 1/4 1b. $25 \mathrm{c}$; 1b. $60 \mathrm{c}$.

FRENCH BREAKFAST-A variety of quick growth; mild and tender; good for forcing; oz. $10 \mathrm{c} ; 1 / 4$ tb. $25 \mathrm{c}$; 1 b. $60 \mathrm{c}$.

YELLOW SUMMER TURNIP-An early and excellent summer variety; of russet color; grows larger than any other turnip variety and stands the heat well; oz. 10c: $1 / 4$ 1b. $25 \mathrm{c}$ : $1 \mathrm{~b} .60 \mathrm{c}$.

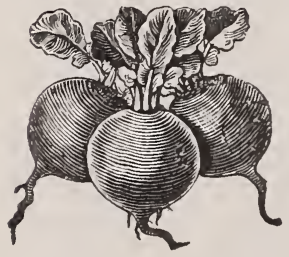

CHINA ROSE-Winter; grows large and tender; is becoming a very popular variety; half long; very smooth; firm and tender and of fine flavor; oz. $10 \mathrm{c}$; $1 / 4$ tb. $25 \mathrm{c}$; 1b. $60 \mathrm{c}$.

BLACK SPANISH - Long - One of the hardiest and best for winter use; oz. $10 \mathrm{c} ; 1 / 4$ tio. $25 \mathrm{c}$; 1b. $60 \mathrm{c}$.

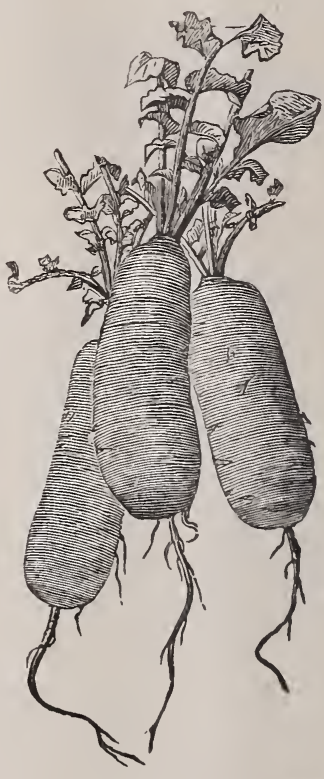

\section{RHUBARB}

Sow in March, in drills a foot apart, thinning out to about the same distance apart in rows when a few inches high; in fall transplant to about three feet apart each way. The large roots are easily forced if packed closely under the stage of a greer. house or warm cellar, as no light is necessary for the development of the stalk.

LINNEAUS-Early, large and tender; oz. 15c; $1 / 4$ tb. 50c.

VICTORIA-Later than the Linnaeus; very large; oz. $15 \mathrm{c} ; 1 / 4 \mathrm{lb} .50 \mathrm{c}$.

We prepay postage on all Garden and Flower seeds except Peas, Beans and Corn. 


\section{SALSIFY, OR OYSTER PLANT}

Sow on rich soil early in spring, in drills fourteen inches apart; the roots will be ready in October, and can be left in the ground until spring.

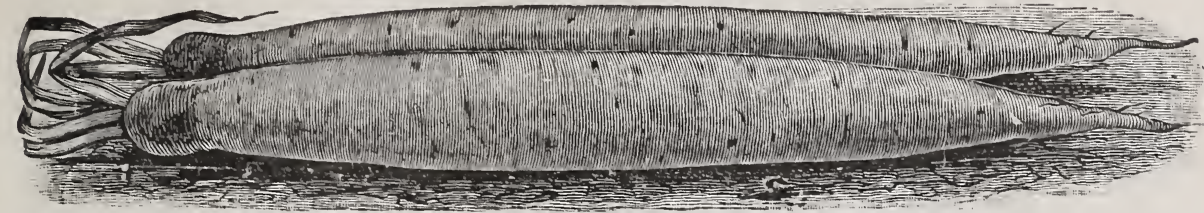

MAMMOTH SANDWICH ISLAND-A new and larger growing variety than the old sort. Price: Oz. 20c; $1 / 4$ Ib. $40 \mathrm{c}$; 1b. $\$ 1.50$.

\section{SPINACH}

For summer use sow early in the spring in drills eight inches to one foot apart cover the seed one inch. For very early spring use sow in August or September; cover lightly with straw.

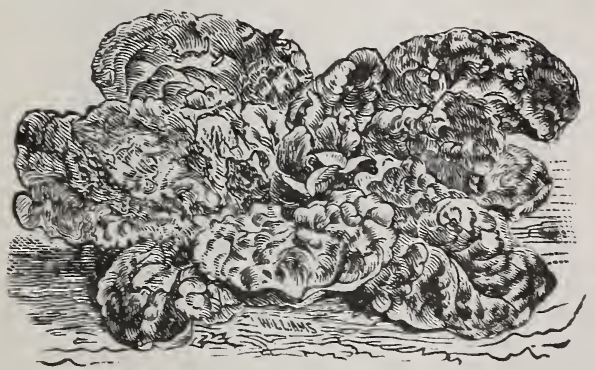

LONG STANDING-The leaves are thick and of excellent flavor; is noted for being the latest to run to seed; desirable: oz. $5 \mathrm{c} ; 1 / 4$ Ib. $10 \mathrm{c}$; 1b. $25 \mathrm{c}$

ROUND LEAVED - Excellent market sort; equally good for spring and fall sowing; leaves large, thick, fleshy oz. 5 c; $1 / 4$ Ib. $10 \mathrm{c} ; 1 \mathrm{~b} .25 \mathrm{c}$.

THICK LEAVED VIROFLAY-This is very large, thick leaved; good for fall or spring sowing: oz. 5c; $1 / 4$ lb. $10 \mathrm{c}$ : Ib. $25 \mathrm{c}$

HENDERSON'S NORFOLK SATOY LEAVED-Very productive; leaves curled like Savory Cabbage; oz. 5c: 1/4 tb. $10 \mathrm{c}$ : $1 \mathrm{~b} .25 \mathrm{c}$

\section{SQUASH}

Sow about the middle of spring in hills, the early sort about four feet apart, and the late varieties six to eight feet; drop enough seeds to be thinned to three plants to a hill.

EARLY WHITE BUSH OR WHITE .PATTY PAN-Light cream color, flat and scalloped shaped: oz. 10c: 1/4 tb. 25c; tb. $75 \mathrm{c}$

SUMMER CROOKNECK-Very productive: small crookneck; yellow color; shell very hard when ripe; oz. $10 \mathrm{c}$; $1 / 4$ Ib. $25 \mathrm{c}$; 1b. $75 \mathrm{c}$.

GOLDEN BUSH-A fine, early summer sort; yellow; fine flavored: oz. 10c; 1/4 Ib. $25 \mathrm{c}$; ib. $75 \mathrm{c}$.

MAMMOTH CHILI-Grows to an immense size; excellent for all purposes; oz. 10c; $1 / 4$ tb. $50 \mathrm{c}$; 1b. $\$ 1.50$.

BUTMAN-In size and productiveness it resembles the Hubbard; has a thick shell and is thick meated; shell is of a bright grass green color, intermixed with white; a good keeper; oz. $10 \mathrm{c}$; $1 / 4$ ib. $25 \mathrm{c}$; 1b. $75 \mathrm{c}$.

FORDHOOK-A strong and rapid grower; earlier in ripening than any other winter

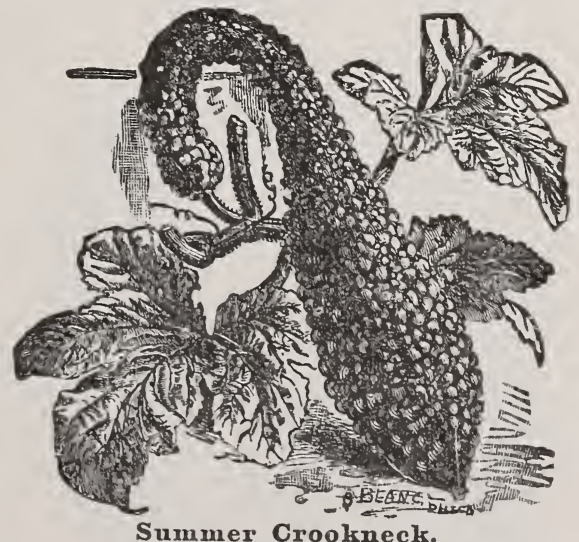
squash; the color is bright yellow outside and straw color within; the skin is very thin, meat thick, and seed cavity small; this variety is very productive and one of the best keepers; oz. 15c; 1/4 Ib. $40 \mathrm{c}$; tb. $\$ 1.25$.

MARBLEHEAD-Has a gray, hard shell; resembles the Hubbard in shape; is a good keeper; oz. $10 \mathrm{c}$; $1 / 4$ 1b. $25 \mathrm{c}$; 1b. $75 \mathrm{c}$. 


\section{SQUASH---Continued}

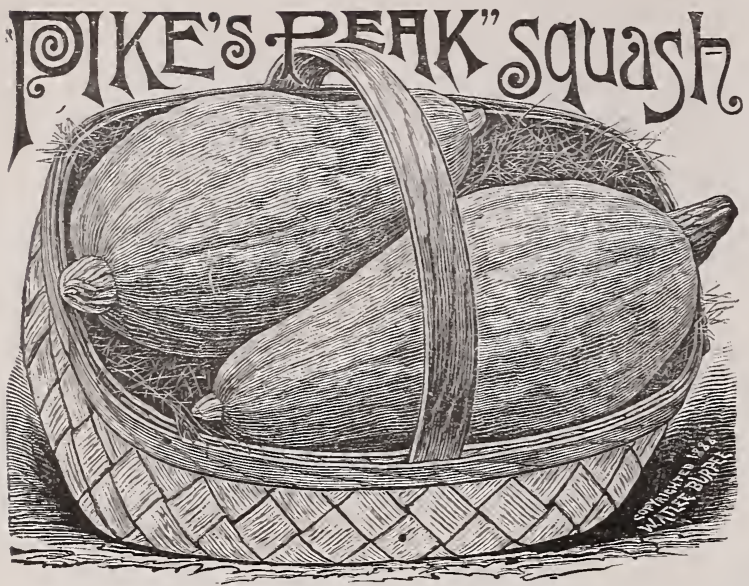

SIBLEY OR PIKE'S PEAK-Shell is a pale slate color, very hard, but so smooth and thin there is no waste in baking; flesh is solid and thick, a brilliant orange color, dry, and of a rich delicate flavor. Plant plenty seed as they are more difficult to germinate than others; oz. $10 \mathrm{c} ; 1 / 4$ tb. $30 \mathrm{c} ;$ tb. $\$ 1.00$.

BOSTON MARROT-One of the very best for fall and winter use; form ovate pointed; rind thin, bright orange; flesh deep orange; fine grained: excellent flavor; oz. $10 \mathrm{c} ; 1 / 4$ tb. $20 \mathrm{c}$; 1b. $65 \mathrm{c}$.

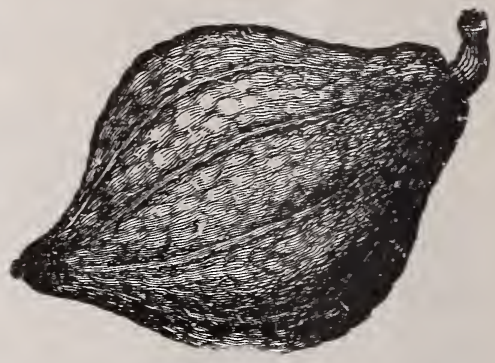

Hubbard.

TURBAN-Flesh orange yellow; thick, fine grained and $\pi$ ell flavored; oz. $10 \mathrm{c} ; 1 / 4$ tb. $25 \mathrm{c}$; tb. $65 \mathrm{c}$.

PERFECT GEM-Small, flattened, slightly ribbed; creamy white color; dry, sweet, fine flavored; very productive; oz. $10 \mathrm{c} ; 1 / 4$ tb. $25 \mathrm{c}$; 1b. $75 \mathrm{c}$.

\section{TOMATO}

For early use sow in hot beds or box in a sunny exposure in the house; they grow much better if transplanted when two or three inches high; when five or six inches high, if the ground is warm, transplant to the open ground on a cloudy day if possible; set the plants about four feet apart each way, on mounds, so that the sunlight will reach the

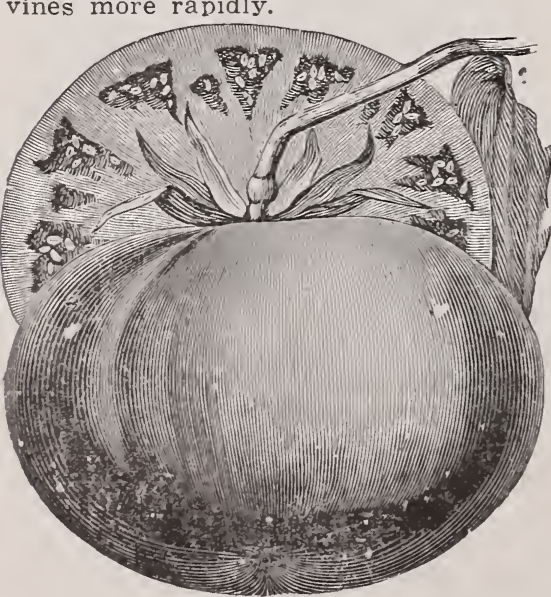

Acme.
LIVINGSTON'S NEW DWARF STONE-The Dwarf Stone is fully double the size of Dwart Champion, and yet equally as early. It is fully as prolific and more productive. The largest fruited upright growing variety in existence. Package $10 \mathrm{c}$; oz. 35c.

DWARF CHAMPION-Is of a dwarf, stiff hahit, needing scarcely any support; it is very early and wonderfully prolific; a deep red, medium size, round and smooth; very few seeds; oz. $30 \mathrm{c} ; 1 / 4$ tb. $\$ 1.00$.

EARLY ACME-A standard variety; very productive; fruit of medium size, round and smooth; color dark purplish red; bears continually until frost; no core; splendid for market; oz. 20c: $1 / 4$ th. $60 \mathrm{c}$.

THE STONE*-As its name indicates, it is very large, solid and heavy; very smooth and of a bright scarlet color; ripening evenly to the stem without a crack; fine for canning and good for general crop; a good shipper; oz. $20 \mathrm{c} ; 1 / 4$ Ib. $60 \mathrm{c}$.

*Canning Varieties. 


\section{TOMATO---Continued}

THE MANGUS-Thick, heavy solid meat; very smooth; it ripens evenly; does not crack; it is unsurpassed in quality; color of Beauty and Acme; it is grown both early and main crop; last season it led all others in productiveness among Pueblo gardeners; oz. $20 \mathrm{c} ; 1 / 4$ tb. $60 \mathrm{c}$.

PEAR SHAPED YELLOW-Used for preserving, same as figs; oz. $30 \mathrm{c} ; 1 / 4$ Ho. $\$ 1.00$.

PEACH-New-Resembles the peach in shape and color; about two inches in diameter, of a deep rose color; is very solid and unequalled in flavor; excellent for preserves, also for canning; packet 10c; oz. $35 \mathrm{c}$.

LIVINGSTON'S ROYAL RED*-A new variety that has proved in some sections the best main crop tomato for market gardeners; fruit large, perfectly smooth, of a vivid red color without any purple tinge; a good tomato for shipping, canning or slicing for table use; oz. $20 \mathrm{c} ; 1 / 4 \mathrm{tb} .60 \mathrm{c}$.
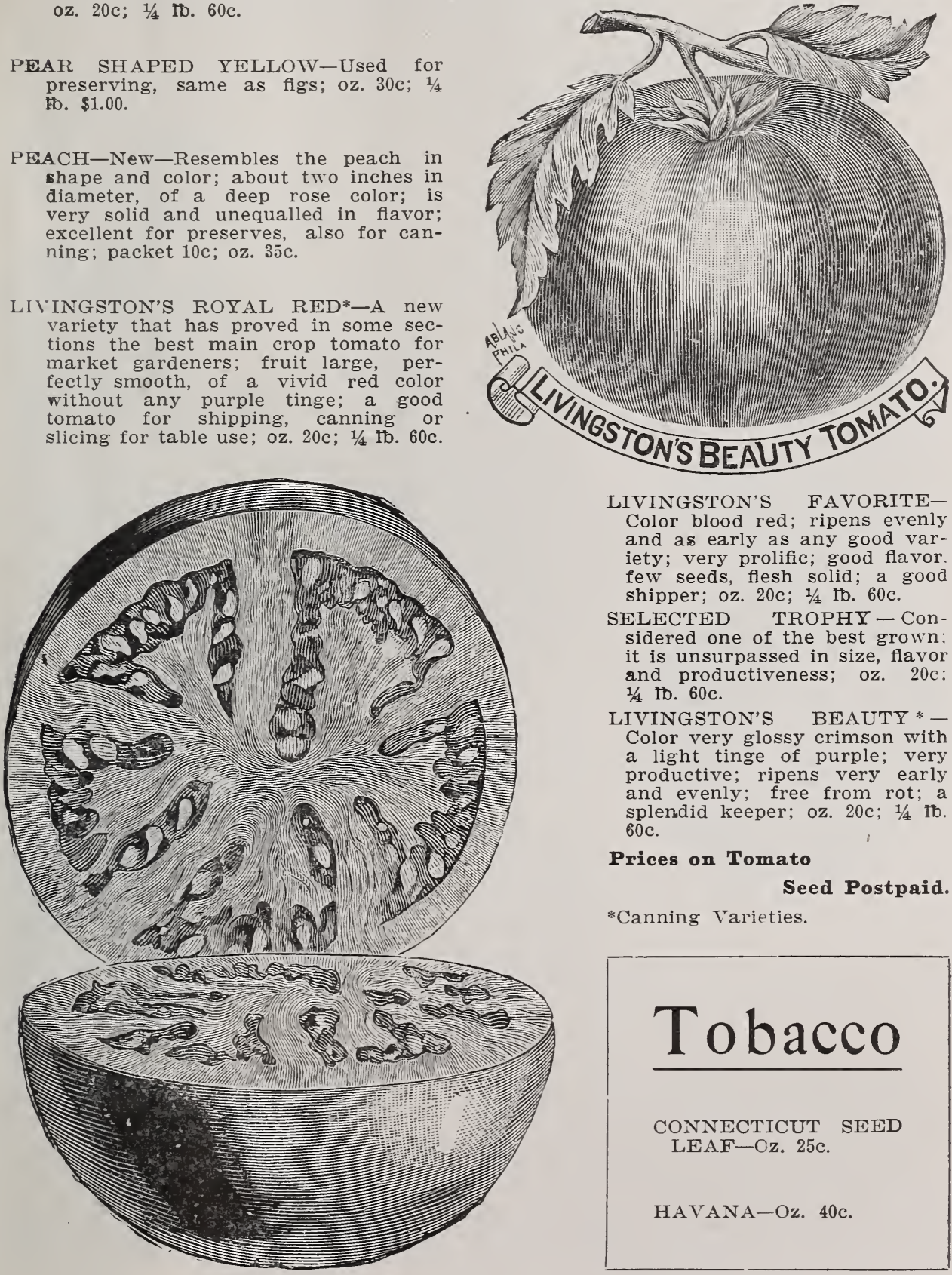

LIVINGSTON'S FAVORITEColor blood red; ripens evenly and as early as any good variety; very prolific; good flavor. few seeds, flesh solid; a good shipper; oz. 20c; $1 / 4$ tb. $60 \mathrm{c}$.

SELECTED TROPHY - Considered one of the best grown: it is unsurpassed in size, flavor and productiveness; oz. 20c: $1 / 4$ tb. $60 \mathrm{c}$.

LIVINGSTON'S BEAUTY * Color very glossy crimson with a light tinge of purple; very productive; ripens very early and evenly; free from rot; a splendid keeper; oz. 20c; $1 / 4$ to. $60 \mathrm{c}$.

Prices on Tomato

Seed Postpaid.

*Canning Varieties.

\section{Tobacco}

\section{CONNECTICUT SEED \\ $\mathrm{LEAF}-\mathrm{Oz}$. 25c.}

HAVANA-Oz. 40c. 


\section{TURNIPS}

For the spring crop sow as early as the seed can be got into the ground, in fourt en inch drills, thin to five or six inches; for the fall crop sow from the middle to the last of July, for a succession, at intervals of two weeks; as the.seed is very fine, it requires to be covered very thin.

PURPLE TOP MILAN-An early strap leaf variety; the bulbs are white with purple top; round, flattened and solid; very slender tap root; flesh pure white, sweet and crisp; oz. $10 \mathrm{c} ; 1 / 4$ 1b. $35 \mathrm{c}$; 1b. $\$ 1.00$.

EARLY PURPLE TOP MUNICH-Is very early, with a bright purple top and fine mouse-tailed root; flesh white and of a delicious flavor; oz. $10 \mathrm{c} ; 1 / 4$ tb. $25 \mathrm{c}$; 1b. $80 \mathrm{c}$.

JERSEY NAVET-A good variety for early or fall use; white and very sweet; used by market gardeners around Pueblo for an early variety; oz. $10 \mathrm{c} ; 1 / 4$ 1b. $25 \mathrm{c}$; 1b. $80 \mathrm{c}$.

EARLY WHITE FLAT DUTCH-An early white fleshed variety of quick growth; excellent quality; oz. 10c; $1 / 4 \mathrm{lb}$. $20 \mathrm{c}$; 1b. $50 \mathrm{c}$.

EARLY WHITE EGG-It is perfectly smooth, of a pure, clear white; grows half above the ground; of excellent flavor; a first-rate keeper; oz. 10c; 1/4 Ib. 20c; 1b. 50c.

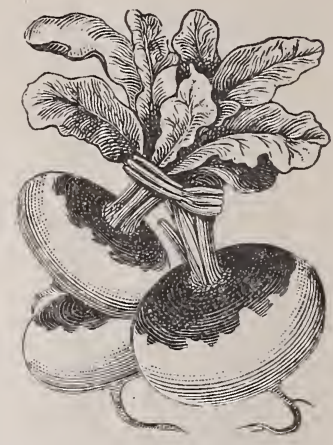

PURPLE TOP WHITE GLOBE-A very rapid grower,

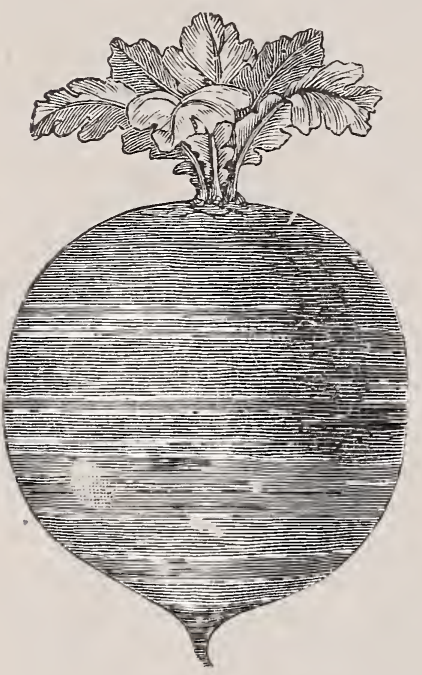
for early or late sowing; oz. $10 \mathrm{c}$; $1 / 4$ 1b. $20 \mathrm{c}$; $1 \mathrm{~b} .50 \mathrm{c}$.

PURPLE TOP STRAP LEAF-A rapid grower and a standard variety; flat; oz. $10 \mathrm{c}$; $1 / 4 \mathrm{tb}$. $20 \mathrm{c}$; $1 \mathrm{~b} .50 \mathrm{c}$.

YELLOW GLOBE-One of the best varieties for general use; oz. $10 \mathrm{c} ; 1 / 4$ 1b. $20 \mathrm{c} ; 1 \mathrm{~b} .50 \mathrm{c}$.

IMPROVED GOLDEN BALL-Rich and sweet; unsurpassed for its quick growth and excellent quality; keeps well; oz. $10 \mathrm{c}$; $1 / 4$ 1b. $20 \mathrm{c}$; 1b. $60 \mathrm{c}$.

YELLOW ABERDEEN-Very hardy and productive: good keeper; globe shaped; fine quality; oz. 10c; $1 / 4$ 1b. $20 \mathrm{c}$; 1b. $50 \mathrm{c}$.

WHITE GLOBE-Globe shaped; good for table or stock use; grows large; oz. $10 \mathrm{c} ; 1 / 4$ 1b. $20 \mathrm{c}$; 1b. $50 \mathrm{c}$.

COW HORN-Matures quickly; flesh white; fine grained; sweet; excel-

lent for table use; oz. $10 \mathrm{c} ; 1 / 4$ tb. $20 \mathrm{c}$; 1b. $50 \mathrm{c}$.

BURPEE'S BREADSTONE-While of the Ruta Baga type they are of $\mathrm{such}$ excellent quality they should be classed as a turnip; oz. 10c; $1 / 4$ 1b. $25 \mathrm{c} ; 1$ b. $85 \mathrm{c}$.

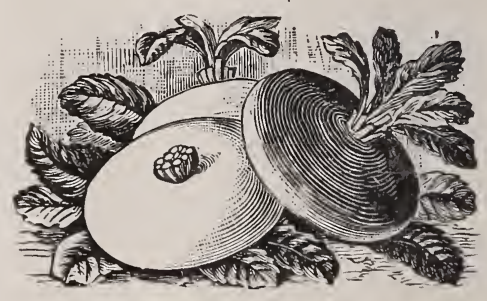

\section{RUTA BAGA}

Sow from June 20th to last of July; cultivate same as turnips, except the drills should be twenty inches to two feet apart; thin to eight inches.

AMERICAN YELLOW-Very hardy and productive; flesh yellow, solid, sweet, fine flavored; oz. $5 \mathrm{c}$; $1 / 4$ tb. $15 \mathrm{c}$; 1b. $50 \mathrm{c}$.

SKIRVING'S YELLOW PURPLE TOP-Flesh yellow, of solid texture; very popular variety; oz. $5 \mathrm{c} ; 1 / 4$ 1b. $15 \mathrm{c}$; 1b. $50 \mathrm{c}$.

We Prepay Postage on all Garden and Flower Seeds Except Peas, Beans and Corn. Add Eight Cents Per Pound If Sent By Mail. 


\section{FIELD SEEDS}

(MARTET PRICE.)

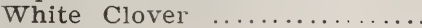

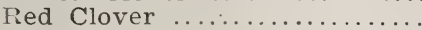

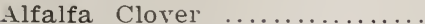

Millet, common .............

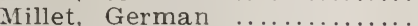

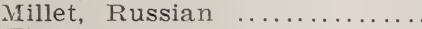

Timothy $\quad \ldots \ldots \ldots \ldots \ldots \ldots \ldots \ldots$

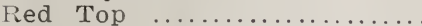

t)ats, Colorado Grown ..........

Barley, Bald and Hulless

per cwt

Kaffir Corn, Red or White

Kentucky Blue Grass. extra

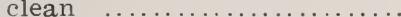

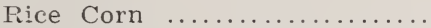

Kentucky Blue Grass, fancy

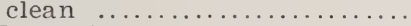

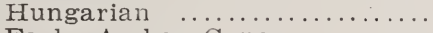

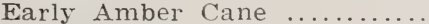

Broom Corn

Rye

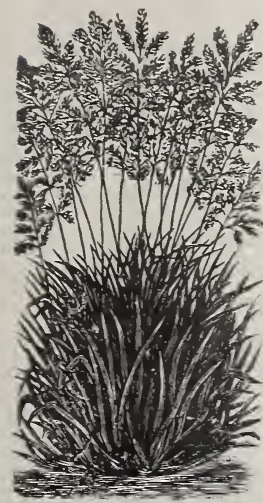

Blue Grass

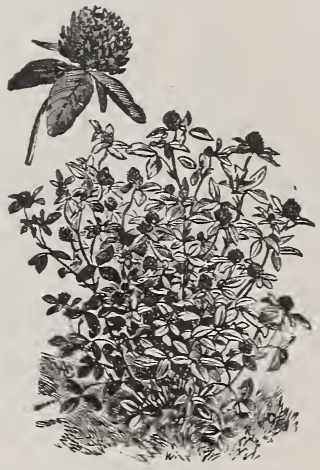

Red Clover.

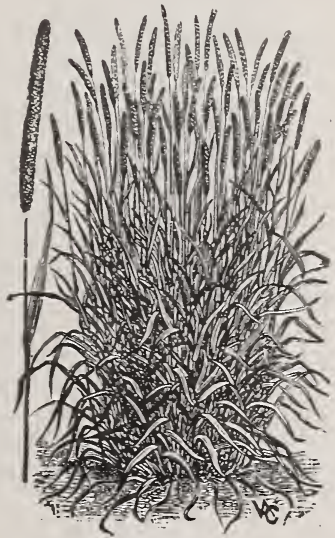

Timothy.

TIMOTHY.

Timothy is grown more extensively every year, and has proven to be one of the best crops for hay in the foothills that can be sown. Sow twenty to twenty-five pounds to the acre. Market price.

\section{BLUE GRASS.}

Kentucky Blue Grass, fancy cleaned, used principally for lawns, and sown in the foothills for pasture it does remarkably well. For lawns, use one pound to ten feet square; for pasture about tmenty-eight pounds to the acre. Market price.

\section{ORCHARD GRASS.}

Extremely hardy; one of the earliest to start in the spring; makes good pasture and excellent hay. A great many sow orchard grass with Alfalfa in the foothills. Sow about twenty pounds to the acre. Market price.

\section{RED TOP.}

We carry both clean and fancy grades. Thrives best in low lands, making a very firm sod. Does $\pi$ rell in Colorado, and is grown quite extensively in the foothills. Sow from eighteen to trenty pounds to the acre. Market price.

\section{BROMUS INERMIS.}

Bromus Inermis (Brome Grass), beardless. The introduction of this variety into the arid and semi-arid regions of the West and Northwest has given the people a pasture and meadow grass of great promise. This grass has been grown with success on the Divide east of the mountains, and should be used by all that have a shortage of water for irrigation. Try a few pounds. Market price 


\section{FIELD SEEDS---Continued}

\section{RED CLOVER.}

Red Clover is used more every year, and while not as productive as alfalfa, it is sown by a great many in orchards. Twelve to fifteen pounds to the acre. Market price.

\section{WHITE DUTCH CLOVER.}

Used with Blue Grass for lawns, makes good sheep pasture and is a fine pasture for bees; must be sown where it will have plenty of moisture. Market price.

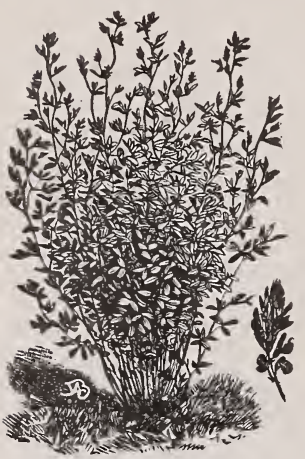

\section{ALFALFA OR LUCERENE CLOVER.}

A valuable forage plant, and is becoming more extensively used as its worth is known. It requires a rich deep soil. The sun must have free access to alfalfa, and the ground must be rolling to enable the water to pass off readily. A wet underground is fatal to the plant. A great many sow in connection with oats. The latter should be sowed first and harrowed in, and then sow from twenty to twenty-five pounds to the acre of alfalfa seed, and roll the ground well. It is best when cut in bloom. It will not shed rain like other hay, and must be either stored in sheds or covered with canvas. After being cut,alfalfa should lie until it wilts, and then cured in the cock, else the leaves become dry, crumbles off, and the best part of the crop is lost. It is an all round feed for all kinds of stock. Alfalfa pasture is the very best for all kinds of stock. Market price.

\section{BARLEY.}

HULLESS AND BEARDLESS-It is very productive and does equally as well in migh and low altitudes. The straw is of good length and strong, the heads look very much like wheat. This is not a brewing barley, but is used for feeding stock. Our seed is Colorado grown. Market price.

\section{FIELD CORN.}

(Colorado Grown.)

Our Field Corn we have grown for us in Pueblo County, and we find that it does much better than corn shipped from the east, so order early. Market price.

WHITE AUSTRALIAN CORN-It is an early flint corn, used by a great many for roasting ears. For those who have no water for irrigation, this is one of the best varieties. Very fine for hominy.

WHITE DENT-This is a very fine white corn and preferred by some to the Yellow Dent. Market price.

YELLOW DENT-(Mountain Grown Seed)-This variety we have sold for the past few years in small quantities, not being able to secure the seed in quantities enough to justify quoting in our catalogue. We will have a small surplus to offer this season at market price. This is a very productive corn, more suitable to the foothills and mountain districts, and thoroughly acclimated. Very early.

COLORADO YELLOW DENT-This is Colorado grown seed; well acclimated and good cropper.

BLOODY BUTCHER OR CALICO-We have a small quantity of this variety for sale this season. Market price. 


\section{ONION SETS}

(MARKET PRICE.)

Write us for prices in large quantities.

Per to.

Top sets, red $\ldots \ldots \ldots \ldots \ldots \ldots \ldots \ldots \ldots \ldots \ldots \ldots \ldots$

Yellow Bottom Sets

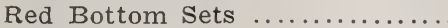

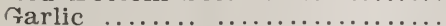

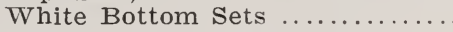

Per to

\section{POP CORN}

WHITE RICE POP CORN-One of the very best varieties grown; a sure cropper and always finds ready sale. Market price.

QUEEN'S GOLDEN-This is a very fine pop corn; a delicate golden yellow; pops out white and large; is very tender. Pound 10c.

\section{RUSSIAN SUNFLOWER}

Raised extensively for chicken feed; does well in low spots. Pound 15c.

\section{BUCKWHEAT}

JAPANESE-(New)-The kernels of this new buckwheat are nearly twice as large as the common kind; it branches more and need not be sown as thickly. It is a very heavy cropper and less apt to blight than other varieties. Market price.

SILVER HULLED-Market price.

\section{AROMATIC, MEDICINAL AND POT HERBS}

Sow in the spring in shallow drills one foot apart; when well up thin out or transplant to a proper distance apart. Gather on a dry day just before they come into full bloom.

ANISE-The leaves used as a garnish and seasoning; the seeds made into tea as

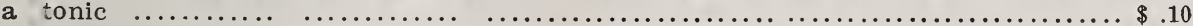

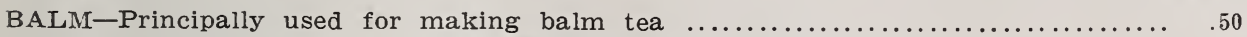

CARAWAY-The seeds are used medicinally and the under leaves in soup...... .10

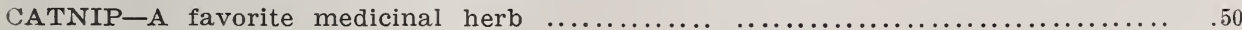

DILL-The leaves are used in soups and sauces and to put along with pickles..... .10

HOREHOUND-Used as a tonic, also in cases of pulmonary complaint..........40

HYSSOP-The leaves are gathered for making Hyssop tea and other purposes.... .30

RUE-Used for medicinal purposes, also given to fowls for the roup $\ldots . \ldots . \ldots . . .30$

SAGE-The leaves are used for seasoning, stuffing, etc. Tea made from the leaves

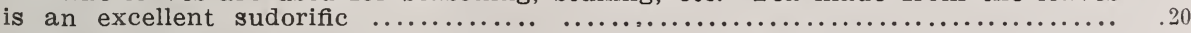

SAVORY SUMMER-Leaves for culinary purposes. If finely powdered and sealed tightly in glass bottles, will retain their flavor for a long time ...............40

TANSY-

THYME-Sweet; used for seasoning. Thyme tea is a cure for nervous headache.

WORMWOOD-Used for medicinal purposes. It is also beneficial to poultry, and should be placed in poultry yards 


\section{PLANTS AND ROOTS}

ASPARAGUS ROOTS.

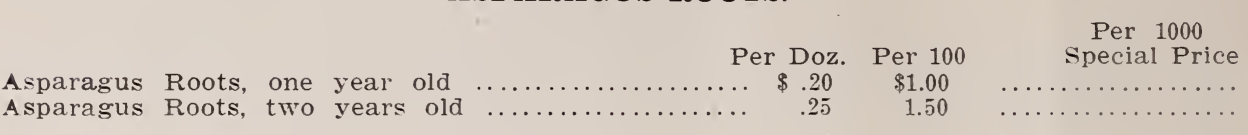

ChIVES.

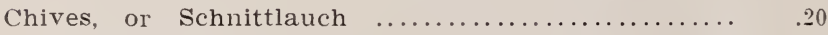

HORSERADISH.

Horseradish

RHUBARB.

Rhubarb $\ldots \ldots \ldots \ldots \ldots \ldots \ldots \ldots$

CABBAGE.

Cabbage, Jersey Wakefield

Cabbage, Early Summer

Cabbage, Iate Varieties ......

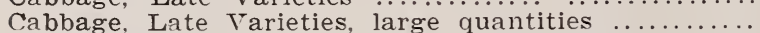

$\begin{array}{ll}.10 & .75 \\ .10 & .75 \\ .10 & .75\end{array}$

Special Price

CELERY.

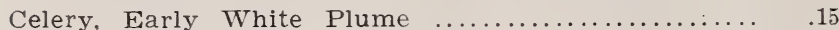

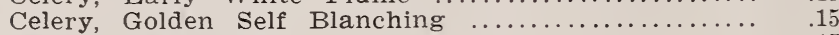

Celery, Giant Pascal

CAULIFLOWER.

Cauliflower, Early Snowball

$.30 \quad 1.75$

EGG PLANT.

Egg Plant, New York Purple

PEPPERS.

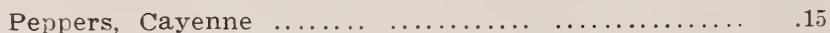

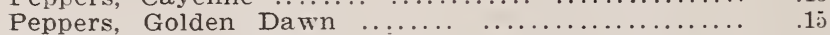

Peppers, Ruby King ...................................

TOMATO TRANSPLANTED.

Tomato, Early Acme ......................... ${ }_{10}$

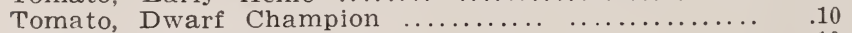

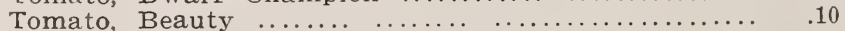

Tomato, Mangus ............................. ${ }^{10}$

Sweet Potato Plants in season. Write for prices.

1.00

1.00

1.00

All plants are hardened before shipment, and will be carefully packed.

Above prices good until stock is sold out. No extra charge for boxes or packing.

\section{STRA WBERRY PLANTS.}

Prices on application: state quantity and variety. We make a low price: no charge for packing.
WM. BELT,
PREMIUM,
PARKER ERLE,
BENDERWOOD,
GANDY. BENDERWOOD AND WARFIELD NO. 2 MIXED.

\section{LUCRETIA DEWBERRY PLANTS.}

\section{"DWARF ESSEX" RAPE.}

\section{A Secondary and Catch Crop.}

Often fine rape may be grown on land that has already produced a crop of some of the early maturing cereals, such as rye, oats or barley. It is used as a soiling crop or pasturage for sheep or swine: ib. 6c. 


\section{TREE SEEDS}

\begin{tabular}{|c|c|c|c|}
\hline Ash White $\ldots \ldots \ldots . \ldots \ldots$. 10,000 & $\$ 10$. & Honey Locust .......... 2,500 & $\begin{array}{l}\text { Tb. } \\
\$ .30\end{array}$ \\
\hline Box Elder ............. 15,000 & .35 & Mulberry ..........200,000 per oz & .25 \\
\hline Black Locust ......... 30,000 & .35 & Osage Orange ......... 10,000 & .30 \\
\hline Catalpa .............. 20,000 & 1.00 & & \\
\hline
\end{tabular}

Average Quantity of Seed Sown to an Acre.

\section{IN DRILLS.}

Dwarf Beans ............. 75 to $90 \mathrm{tbs}$

Early Peas ................... to to $95 \mathrm{lbs}$

Marrowfat Peas .............. 70 to 90 lbs

Beets .................... 4 to $5 \mathrm{lbs}$

Mangel Wurzel ................. 6 to $8 \mathrm{hbs}$

Carrots ................... 2 to 3 Ibs

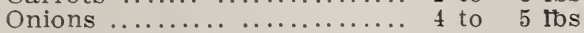

Onions for Sets ................2 20 to $30 \mathrm{fbs}$

Onion Sets ................. 300 to 500 . ths

Parsnips ................... 4 to 5 tbs

Radish ................. 6 to $8 \mathrm{lbs}$
Ruta Baga

Spinach

Salsify

Turnips

Tomatoes to Transplant.

IN HILLS

Corn ................ 8 to 10 lbs

Cucumbers ............... 1 to $1 \frac{1}{2}$ tbs

Musk Melons .............. 1 to 2 fbs

Water melons ................ 2 to 4 ibs

Pumpkins .................. 2 to $4 \mathrm{lbs}$

Squash .................. 2 to $3 \mathrm{lbs}$

\section{Quantity of Seeds Required to a Given Number of Plants.}

Asparagus .......... oz. to 500 plants Cabbage ............... oz. to 2,000 plants Cauliflower .......... oz. to 2,000 plants Celery .............. oz. to 3,000 plants Leek .............. oz. to 1,500 plants Endive ............... oz. to 3.000 plants Egg Plant ............ oz. to 3,000 plants Lettuce ............. oz. to 3,000 plants
Pepper ............. oz. to 1,000 plants Tomatoes ............ oz. to 1,500 plants Thyme ............. oz. to 5,000 plants Tobacco .............. oz. to 15,000 plants Sage ................. oz. to 1,000 plants Savory .............. oz. to 2,000 plants Rhubarb ............. oz. to 500 plants Majoram ............ oz. to 1,500 plants

The Number of Plants, Etc., Required to Set an Acre.

1 foot by 1

foot $.43,560$

$11 / 2$ feet by $11 / 2$ feet $\ldots \ldots \ldots \ldots \ldots \ldots \ldots \ldots \ldots, 360$

2 feet by 2 feet ................ 10,890

$21 / 2$ feet by $21 / 2$ feet $\ldots \ldots \ldots \ldots \ldots \ldots \ldots, 6,670$

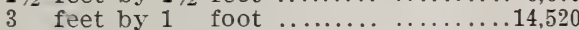

3 feet by 2 feet $\ldots \ldots \ldots \ldots \ldots \ldots \ldots, 260$

3 feet by 3 feet $\ldots \ldots \ldots \ldots \ldots \ldots \ldots \ldots, 8,840$

4 feet by 4 feet $\ldots \ldots \ldots \ldots \ldots \ldots 2,722$

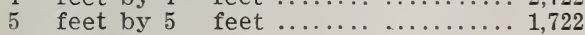

6 feet by 6 feet $\ldots \ldots \ldots \ldots \ldots \ldots \ldots, 1,200$

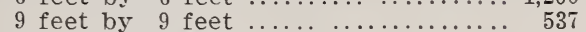

12 feet by 12 feet $\ldots \ldots \ldots \ldots \ldots$

15 feet by 15 feet $\ldots \ldots \ldots \ldots \ldots \ldots \ldots \ldots, 193$

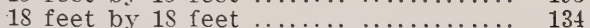

20 feet by 20 feet ................. 108

25 feet by 25 feet $\ldots \ldots \ldots \ldots \ldots \ldots \ldots \ldots . .6 \%$

30 feet by 30 feet ................. 40

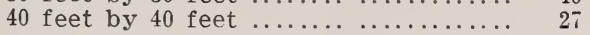

Weights and Measures and Amount of Seeds Sown to the Acre.

per bu. Ibs. to acre Alfalfa Clover .........60 tbs.... 20 to 25 Red Clover .............6 60 tbs.... 12 to 15 White Clover .........6. 160 bs... 6 to 8 Alsike Clover .........66 tbs.... 6 to 8 Timothy ............45 $\mathrm{hbs} . \ldots 20$ to 25 Blue Grass .................. 34 to 40 Red Top ...................... 30 to 40 Mixed Lawn Grass......14 $1 \mathrm{bs} . . .30$ to 40 English Rye Grass.....20 tbs.... 20 to 64 Oats ...................... 32 tbs... 32 to 65 Barley ......................... 60 to 90 Corn .................56 tbs... 8 to 10 Evergreen Millet .. ...20 fbs...2 20 to 30 per bu. tbs. to acre Hemp .............44 tbs.... 32 to 55 Flax ................................ 21 to to 28 Buckwheat ..............52 Ibs.... 36 to 52 Espersett Clover .......28 Ibs.... 20 to 30 Orchard Grass .........14 Ibs.... 20 to 30 Hungarian ................. 48 tos... 30 Common Nillet .........50 $\mathrm{fbs} . . .20$ to 30 German .................. 50 tbs... 25 to 30 Rye ......................... 56 Ibs... to 90 Wheat ..............6 60 Ibs...6 60 to 80 Sugar Beets ........... 6 to 8 Peas-field ............50 $\mathrm{fbs} . . .90$ to 120 Top Onion Sets ........29 Ibs...250 to 300

While we exercise the greatest care to have all the seeds pure and reliable, we do not give any warranty, express or implied. If the purchaser does not accept the seeds on these terms and conditions, they must be returned at once, and the money that has been paid for same will be refunded. 


\section{DIAMOND DOUBLE WHEEL GARDEN CULTIVATOR.}

It has a new device of expanding and closing, which permits the operator to set the machine instantly to any desired width; it is furnished with six cultivators, two furrowers and two cutting knives.

Weight, 30 Pounds.

Price, Complete, $\$ 5.00$.

\section{NEW MODEL SEED DRILL. \\ Try the Latest and Best.}

ITS FEATURES: REGULATION OF DISCHARGE-Drills of similar construction are usually provided with a series of holes of various sizes, through which the seed is passed, which of course, do not always give an opening of exact size required. The operator is usually told, in substance, that "if one hole doesn't suit, try another." This adjustment in the Model is accomplished in a very simple and effective manner by use

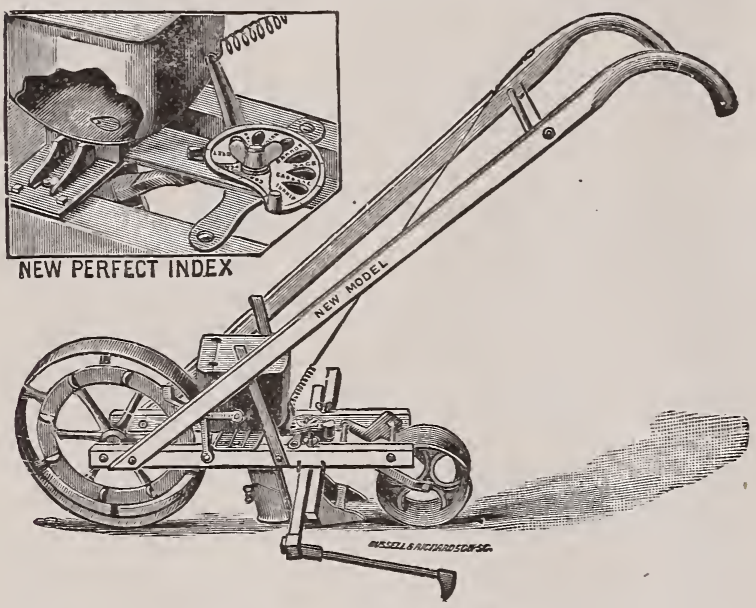
of a slide with a pea shaped opening passing under the bottom of the seed reservoir, which is provided with a perforation of similar shape in a reversed position. This slide can be instantly adjusted to the size indicated by the index, or to a hair breath variation between -a vital point in a perfect seed drill. THE INDEX, or Indicator -is plain, convenient and reliable. It is placed in open sight immediately under the eye of the operator and can be quickly adjusted to the slightest variation desired. As the names of the principal seeds are plainly shown on the index itself, it is not necessary to refer to any table of reference. CUT-OFF-The flow of seeds can be instantly stopped by a swinging cutoff, conveniently operated by a cord and ring on handles. MARKER-Is simple, easily adjusted and firmly held. BROAD WHEEL-The main wheel is of large size and unusual width, preventing its sinking into soft dirt. COVERING ROLLER-It is attached by swinging frame, enabling the operator to roll lightly or otherwise by varying the pressure on the handles. OPENING PLOW-Is of steel, adjustable in depth. Each drill crated and carefully packed for shipment.

Weight, 40 Pounds.

Price, \$7.00.

IMPROVED CAHOON HAND SEED SOWER-This is probably the most popular broadcact sower on the market. They have a force feed and throw the seed from 15

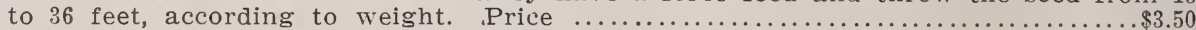

BLACK HAWK CORN SHELLER-A sheller that shells. Can be fastened to box or board. Very easily run, and shells rapidly. Has automatic spring adjustment, adapting itself to all sizes of corn. Weight about 20 pounds $\ldots . \ldots \ldots \ldots \ldots \ldots \ldots 2.50$

ROTARY CORN PLANTER-Decidedly the best hand corn planter made, and a very desirable implement for those who have but a small field, or need to replant their ground. It puts the corn exactly where you want it and at a proper depth. It is easily worked and a most satisfactory tool in every way; it has three seed

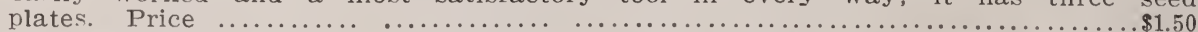

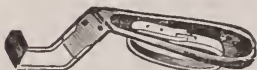

Lang's Hand Weeder,

25 Cents Each.

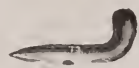

Steel Dibber,

For setting out plants, 25c.

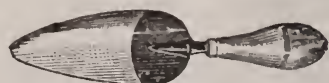

Garden Trowel,

Solid Steel, 50 Cents. 


\section{FERTILIZERS AND POULTRY SUPPLIES}

LAWN FERTIIIZER.

To be used on the lawn in the spring and summer; gives immediate results; soluble; it does not disfigure the lawn like stable manure. One pound will cover about 10 feet square. Ten pounds, $40 \mathrm{c}$; 50 pounds, $\$ 1.50 ; 100$ pounds, $\$ 2.50$.

\section{GARDEN TRUCK FERTILIZER.}

For garden truck and plants-none better. Use in hot beds or greenhouse, and when cabbage, celery and other plants are set out in the open ground; use about one tabiespoonful to each plant when setting out. Be sure to have fertilizer well mixed with soil. In hot bed and greenhouse, use about one pound to a sash, (3x6 feet). Price: 1 Ib. $5 \mathrm{c} ; 10$ tbs. $40 \mathrm{c}$; 50 Ibs. $\$ 1.50$. Special prices in ton lots.

\section{BONE MEAL.}

Used extensively for roses, grape vines and shrubs; also used for chicken feed. Price: 1 ib. $4 \mathrm{c}$; 10 ibs. $35 \mathrm{c}$.

\section{POULTRY SUPPLIES.}

GROUND OYSTER SHELL-Fine or coarse; 1 ib. $3 \mathrm{c} ; 50$ 1bs. $90 \mathrm{c} ; 100$ 1bs. $\$ 1.60$. GRANULATED BONE-1 ib. $4 \mathrm{c} ; 10$ tbs. $30 \mathrm{c}$.

GRANITE GRIT-1 1b. 2c: 10 tbs. $15 \mathrm{c}$.

DRIED MEAT AND BONE-1 tb. 5c; 10 tbs. $40 \mathrm{c}$.

BLOOD MEAL-1 1 fb. $8 \mathrm{c} ; 10$ tbs. $70 \mathrm{c}$.

EGG FOOD (Pratt's)-26 oz. package 25c; 5 tb. package $60 \mathrm{c}$.

PRATT'S STOCK FOOD-50c. per package; sack of $12 \mathrm{lbs}$. $75 \mathrm{c}$.

MYERS' SPICE FOR CHICKENS-Sack 75c.

STONEWARE DRINKING FOUNTAIN-Half gallon 20c; 1 gallon 2ãc.

LEE'S LICE KILLER-One quart 35c; 2 quarts $60 \mathrm{c}$.

CHINA NEST EGGS-Per dozen $30 \mathrm{c}$.

LEG BANDS-Per dozen $20 \mathrm{c}$ and $25 \mathrm{c}$.

By Mail, 16c Extra Per Pound. By Express or Freight at Purchaser's Expense.

PRATT'S LICE KILLER-For poultry; package 10c; per box $25 \mathrm{c}$.

\section{LEE'S LICE KILLER-A Liquid.}

Sure death to all vermin on poultry and hogs, and all domestic animals. Price per quart can 350 ; per 2 quart can $60 \mathrm{c}$.

Full directions on each can.

\section{Send for our Poultry Circular.}

\section{HOT BED SASH.}

Three feet wide, six feet long, $13 / 4$ inches thick, glazed $\ldots \ldots \ldots \ldots \ldots \ldots \ldots \ldots \ldots \ldots$

Three feet wide, six feet long, $13 / 4$ inches thick, not glazed ...................... $\$ 10$ 


\section{THE DOVE-TAILED HIVE}

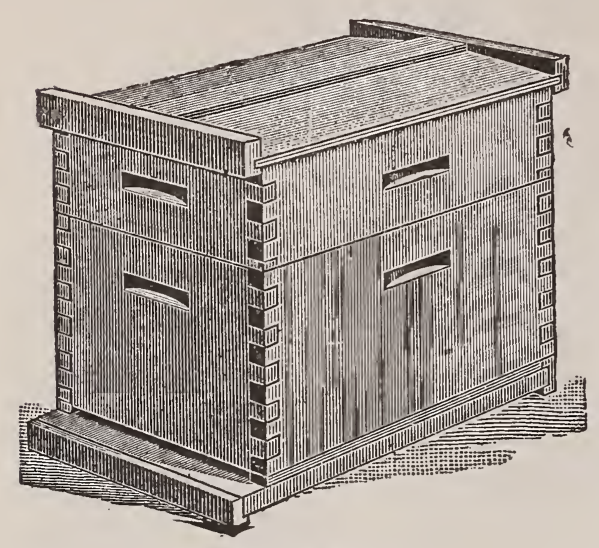

Dovetailed Hive.

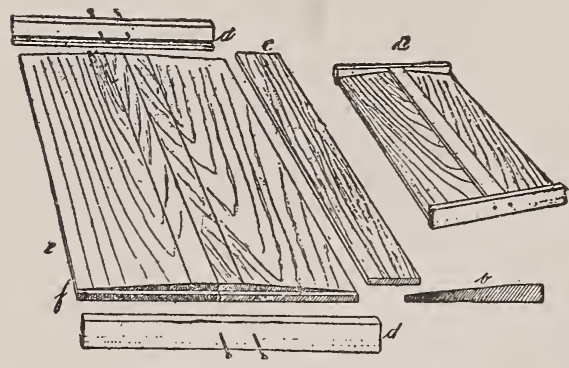

Higginsville Cover.

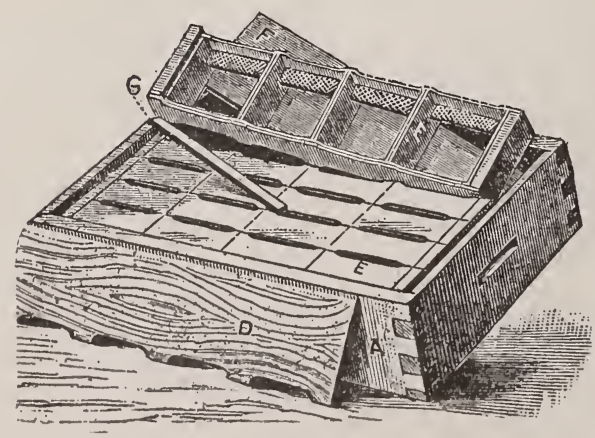

Dovetailed Super.
The standard hive, eight frame and $1 \frac{1}{2}$ stories. The body consists of a plain box, $18 \frac{1}{4}$ inches long, $12 \frac{1}{8}$ inches wide and $91 / 2$ inches inside measure,made of $7 / 8$ lumber and dovetailed at the corner. It has eight self-spacing Hoffman brood frames, metal rabbits and division board.

The super consists of a box, one-half as deep as the hive, which have for their bottom pattern slats, cut the same size and shape as the sections; wood separator and nails go with this hive. Price:

8 frame, $1 \frac{1}{2}$ story, each $\ldots \ldots \ldots \ldots \ldots \$ 1.70$

8 frame, $1 \frac{112}{2}$ story, 5 hives ......... 7.50

8 frame, $1 \frac{11 / 2}{2}$ story, 10 hives ........ 14.00

8 frame, hive bodies, each ........ .50

8 frame, Higginsville hive cover..... .33

8 frame, bottoms ................ .22

Hives are put up five in a crate, and weigh about 140 pounds per crate.

Above prices knocked down.

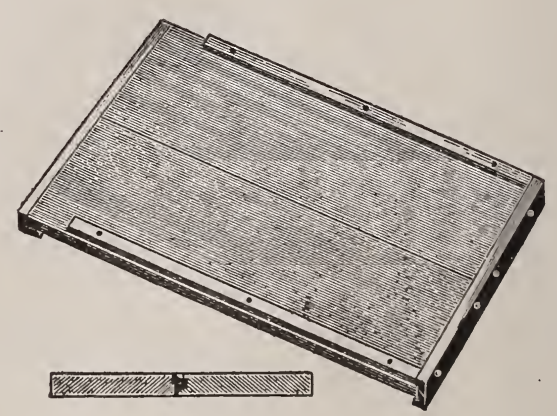

Hive Bottom.

Extra Supers for 8-Frame Hive. Pattern Slats.

Lots of $1 \ldots \ldots \ldots \ldots \ldots \ldots \ldots \ldots \ldots \ldots \ldots$ each Lots of $5 \ldots \ldots \ldots \ldots \ldots \ldots \ldots \ldots \ldots$ each Lots of $25 \ldots \ldots \ldots \ldots \ldots \ldots . . . . .38 \mathrm{c}$ each 


\section{BEE FIXTURES}

\section{SECTIONS}

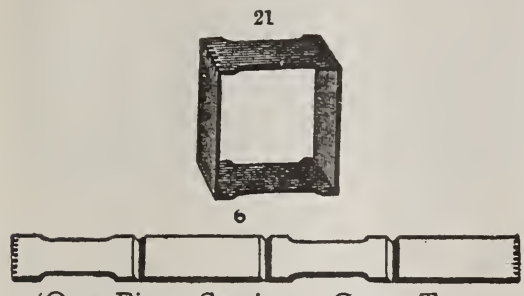

One Piece Section. Open Top.
$4 \frac{1}{4} \times 4 \frac{1}{4} \times 17 / 8$ are the standard section.

The No. 1 section is made from only the whitest basswood.

In lots of $100-$ No. $1 \ldots \ldots \ldots \ldots \ldots .75$

In lots of $500-$ No. $1 \ldots \ldots \ldots \ldots \ldots 2.50$

In lots of $1000-$ No. $1 \ldots \ldots \ldots \ldots . . \ldots 0$

\section{One Piece Section.-Open Top.}

Sections are put up 500 in a crate and weigh about 60 pounds per 1,000 .

\section{SHIPPING CASES}

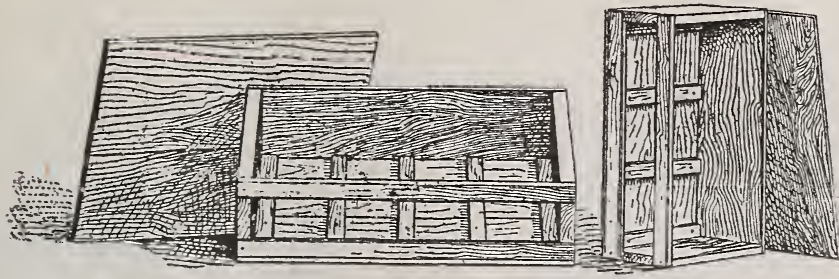

24-1b. single tier, with glass and drip strips, each 25e; in lots of $10 \ldots \ldots \ldots$. $22 \mathrm{c}$ each

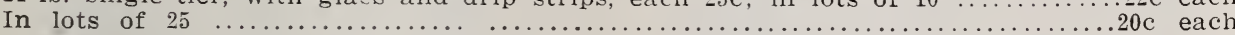
24-1b. cases packed 10 and 25 in a case.

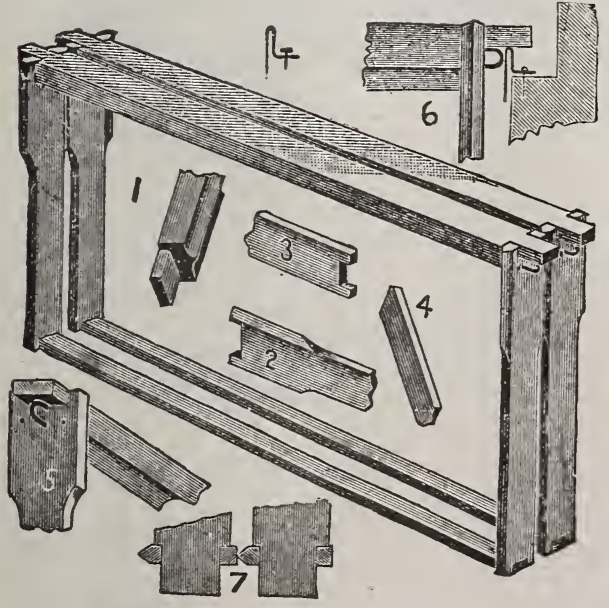

Hoffman Brood Frame.

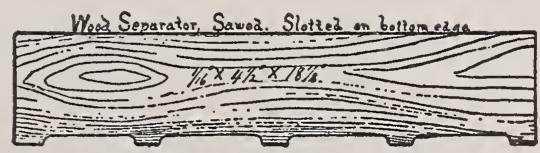

Per 100

Hoffman Brood Frames $\$ 2.75$

Section Holders 2.20

Wood Separators for $4 \frac{1}{4}$ sections..... 1.00 


\section{BEE FIXTURES}
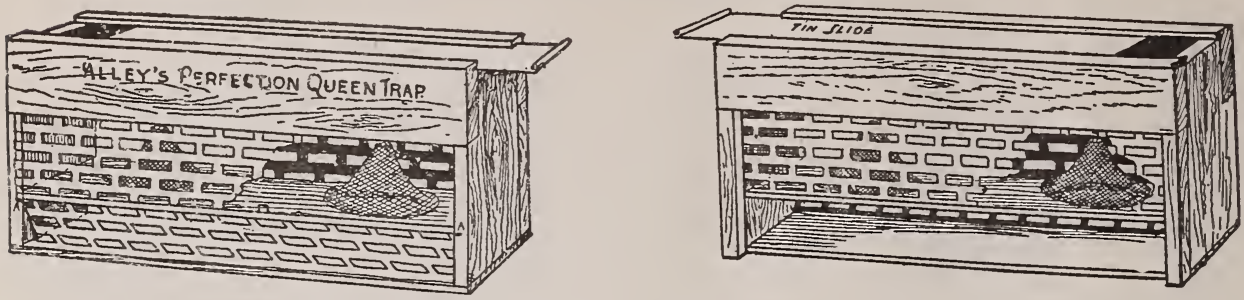

\section{ALLEY'S QUEEN AND DRONE TRAP.}

This will automatically catch and cage the drones in an apartment by themselves. They can then be carried to another apiary, or be destroyed, as circumstances require. The trap will also catch the queen when a swarm issues, and hold her confined until the apiarist can give her his attention. As she cannot get away, the bees will in all likelihood return to the hive. Or if you happen to be on hand when the swarm comes out, the trap with the queen can be placed among the fiying bees. The latter will probably cluster about the queen and they may then be hived. Price 50c; by mail $15 \mathrm{c}$ each extra.

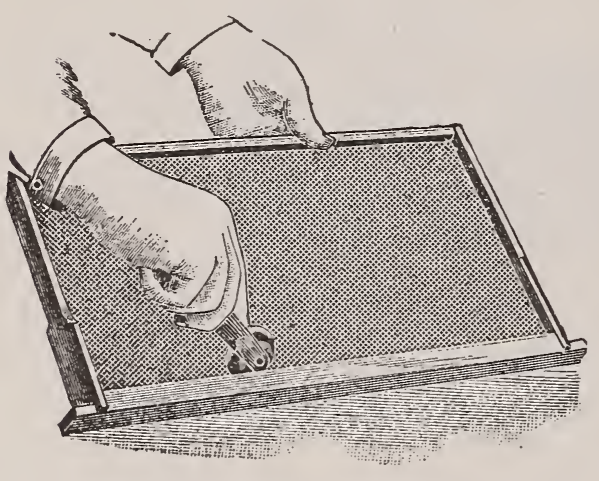

Daisy Foundation Roller.

A very neat little tool for fastening the foundation to the top bar. Price 15c; by mail $18 \mathrm{c}$.

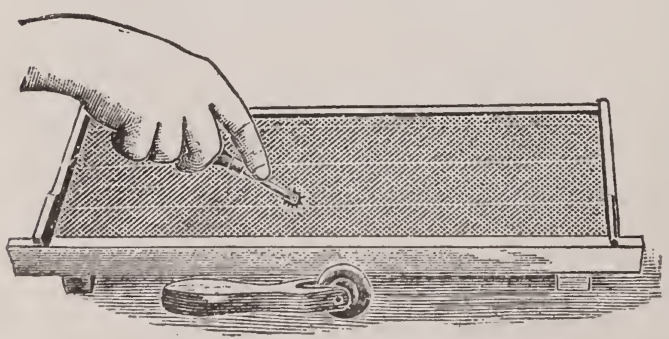

Spur Wire Imbedder.

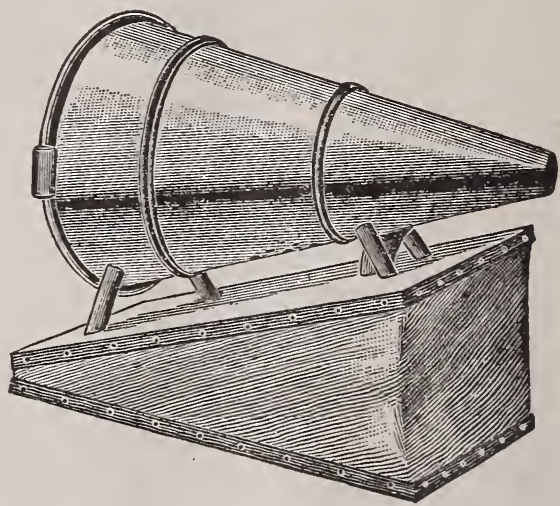

The Clark Smcirer.

This is a cold blast smoker; it is well made, of good size, cheap and serviceable. Price 50c.

\section{Corneil Smoker.}

Price $\$ 1.00$; by mail, add $20 \mathrm{c}$ each for all smokers.

\section{Spur Wire Imbedder.}

This is a little tool like a tracing wheel, with the teeth set in such a way as to straddle the wire while it is in the act of imbedding. Price 15c: by mail $18 \mathrm{c}$ 


\section{BEE FIXTURES}

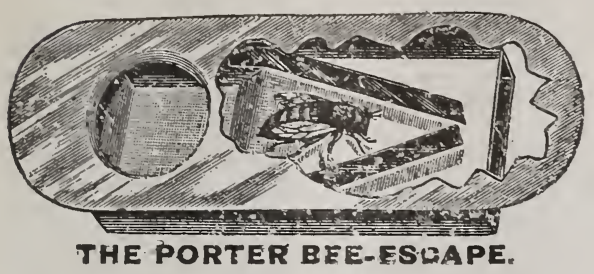

No apiarist can afford to be without bee escapes more than he can afford to be without a bee smoker. In taking off honey it is the greatest labor saving device that has been introduced in late years. It avoids shaking heavy supers to get the bees out, does away with the necessity of smoking them, and the uncapping of honey attendant upon such a procedure; there is no danger of receiving a single sting, and no danger or robbers. All that is necessary is to slip an escape board between the super and brood chamber (say toward night) on each of the colonies from which you desire to remove the honey. The next morning you take supers off the hives. practically free of bees, without disturbing the colony below, and in fact, without using any smoke.

Price 20c each; $\$ 2.25$ per dozen, postpaid.

Price of boards to be used with the above escape, to fit any of our regular hives; single board, nailed, 15c.

Ten or more, nailed, each $12 \mathrm{c}$; ten or more, flat, each $10 \mathrm{c}$.

\section{DOOLITTLE'S SOLAR WAX EXTRACTOR.}

Better than all artificial heat devices is a Solar Wax Extractor. A good one will more than pay for itself in one season.

Price, Each \$4.00.

\section{RAUCHFUSS SOLAR WAX EXTRACTOR.}

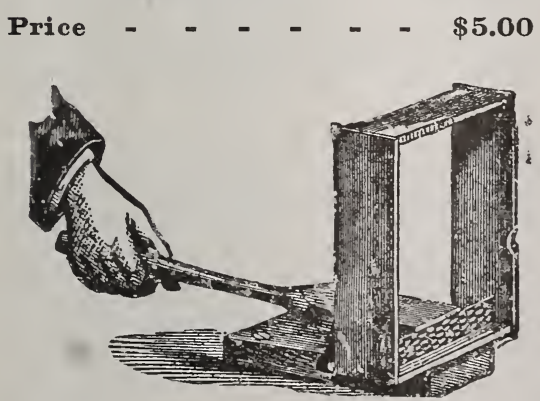

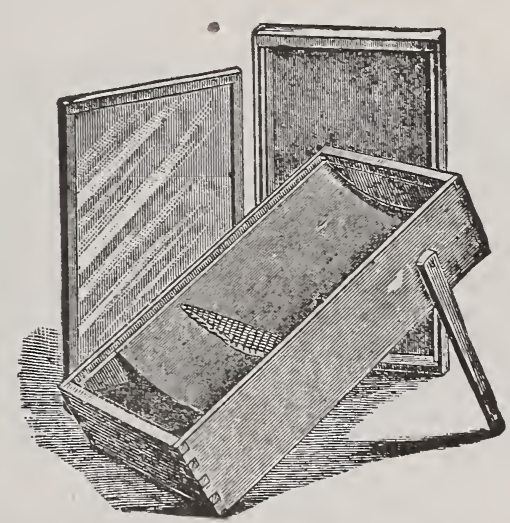

Parker's Machine for Fastening Startex's in Section Boxes.

With a little practice, the machine can be made to work very satisfactory. Price 25c: for our $4 \frac{1}{4} \times 4 \frac{1}{4}$ sections: by mail $40 \mathrm{c}$.

\section{COMB FOUNDATION-Dadants.}

Extra thin surplus, per to $\ldots \ldots \ldots \ldots \ldots \ldots .66^{\prime \prime}$ Medium brood, per 1b................. Subject to Market Change.

Special Price in Quantities.

\section{SUNDRIES.}

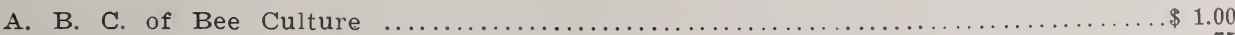

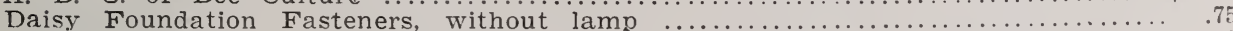

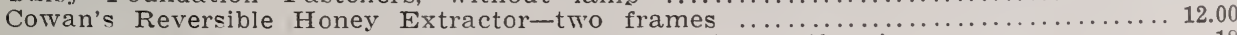

Hive Hooks for fastening supers to hives; per pair $2 c ; 10$ pairs $\ldots \ldots \ldots \ldots \ldots \ldots .18$

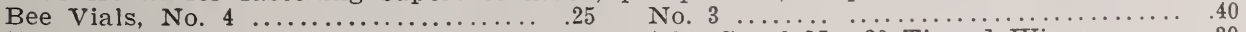

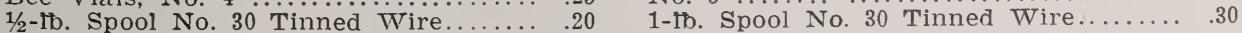




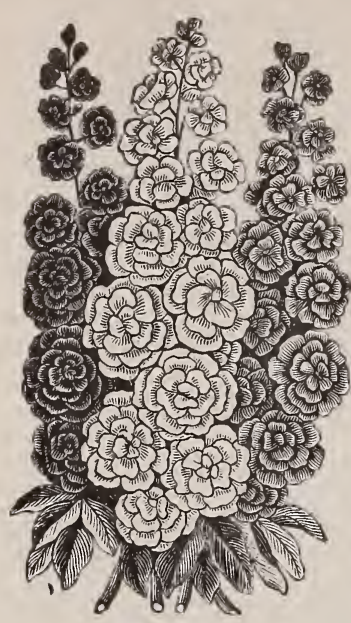

Hollyhock.

\section{SOME CHOICE FLOWERS}

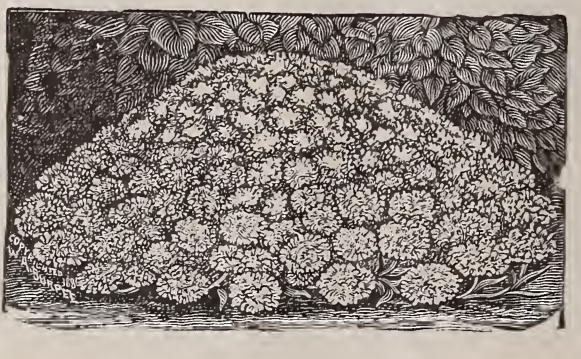

Sweet Alyssum.

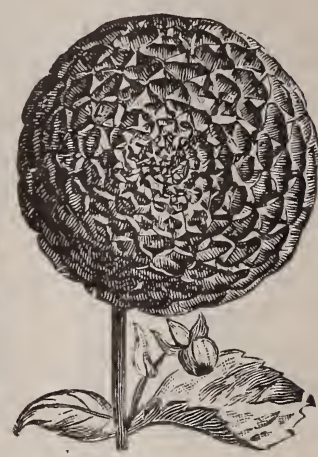

Dahlia.

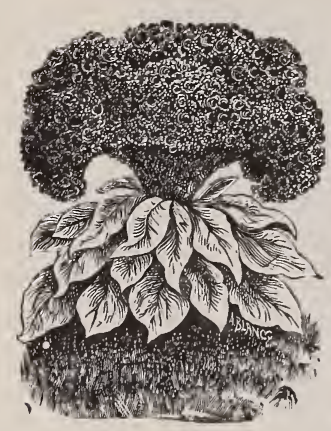

Coxcomb.

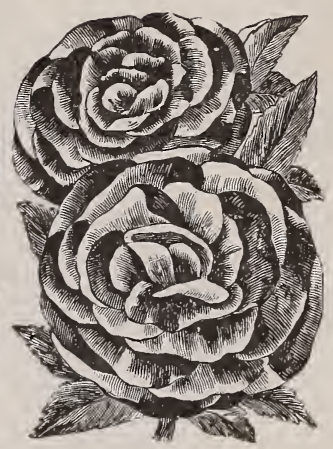

Balsam.

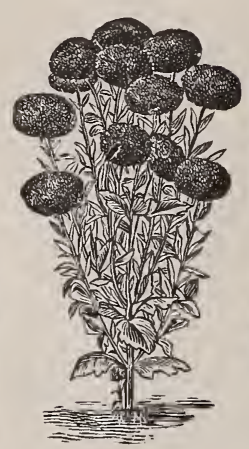

Aster.

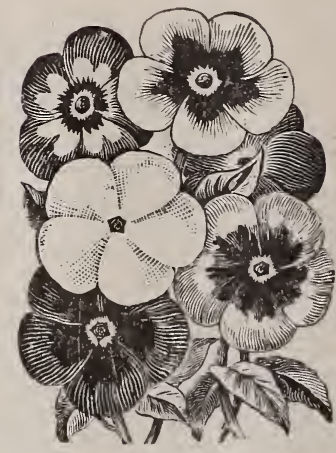

Phlox.

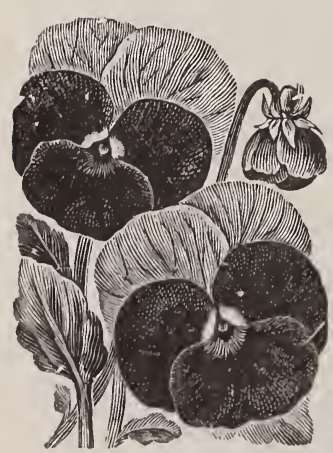

Pansy.

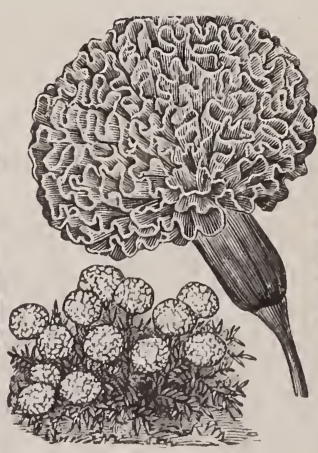

Zennia.

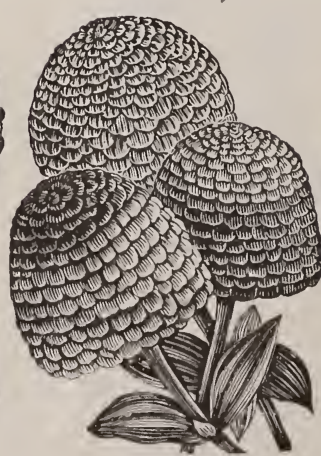

Marigold.

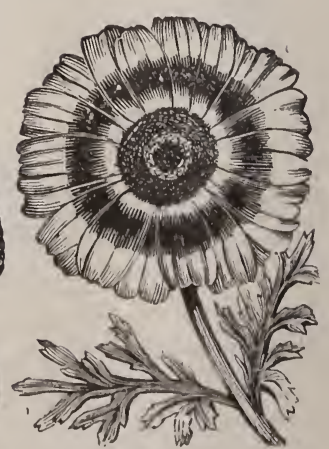

Chrysanthemum. 


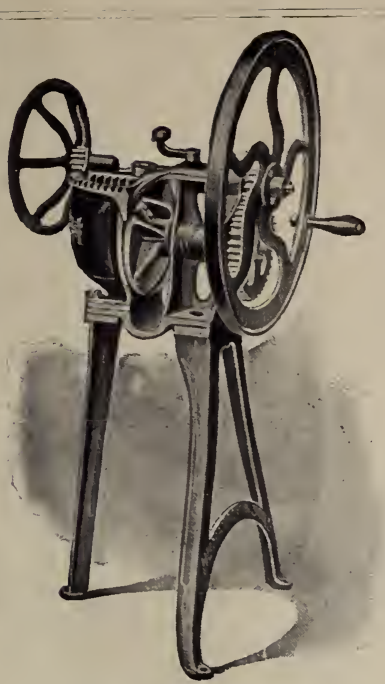

Green Bone Cutter

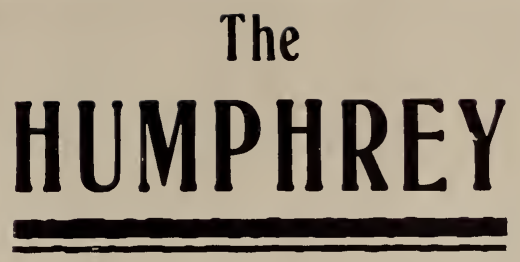

Green Bone and VEGETABLE CUTTER

-the 0pen Hopper Type

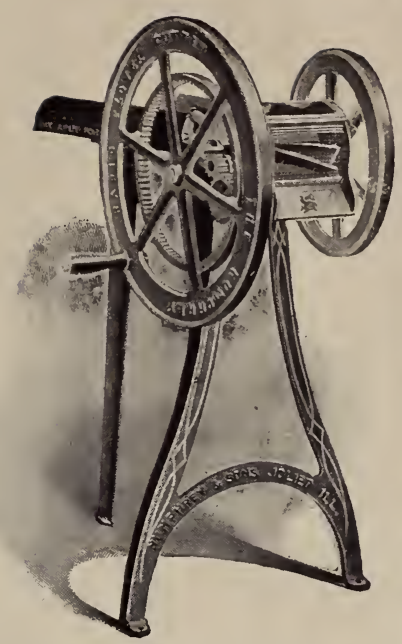

Clover and Alfalfa Cutter

SOLD ON A POSITIVE GUARANTEE TO CUT MORE BONE IN LESS TIME THAN ANY OTHER BONE CUTTER MADE

The Humphrey Clover and Alfalfa Cutter, f. o. b. Pueblo, Colo. . $\quad \$ 11.00$ No. 1 Hand Power Machine, . . . . . . " “ . $\$ 13.00$

No. 1 Machine weighs 120 pounds. Descriptive Circular sent free on application.

\section{We Carry a Full Line of Poultry Supplies}

Send us your address for Price List

MYERS' IMPERIAL BRASS SPRAY PUMP-To be used on pail or tub . . . Price $\$ 5.00$ MYERS' BARREL SPRAY PUMP - This pump is used on a large barrel, and is

suitable for large orchards . . . . . . . . . . . . . . . . . . Price $\$ 9.00$ ASPINWALL SPRAYER-Just what you will need to apply Liquid Lice Killer, white

wash and other insecticides. This is a tin sprayer and holds one quart of liquid. Price $\quad .75$

\section{The Standard Spray Pump}

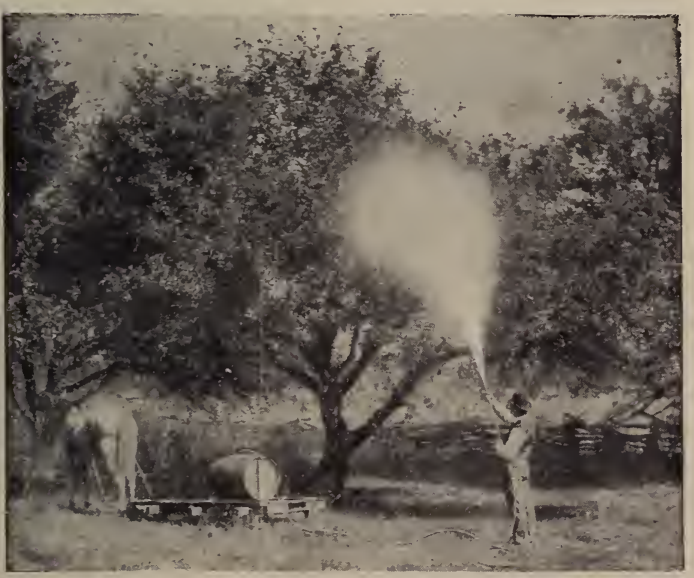

\section{The Standard Spray Pump made entiRely OF BRASS}

No Leathers, Washers or Suckers, no of order The Standard Pump is provided with two Nozzles, inter-changeable. No. 1 throws a fine spray 28 feet. No. 2 throws a solid stream from 55 to 60 feet. No. 1 attached direct to pump throws a coarse spray 35 feet. Pump, two nozzles, and three feet of hose,

PRICE, Each . . . . $\$ 3.50$ 


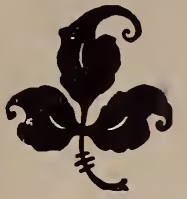

$\$ 300 ; 000,000$ is the estimated value of the Poultry output for 1904 in the U. S. Are you getting your share of the cash? Write us for our Special Price List on Poultry Supplies.
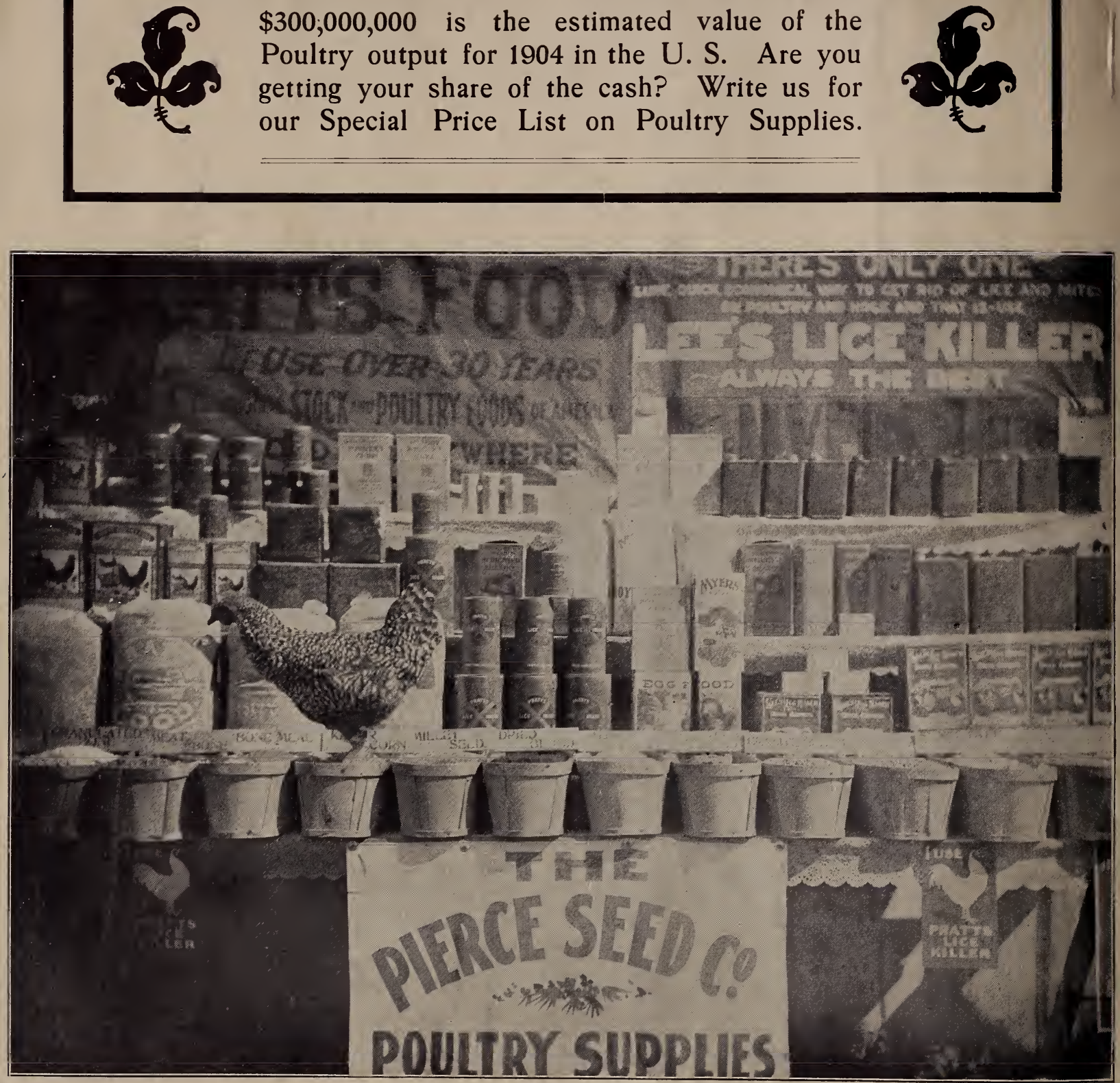

\section{The Pierce Seed Company PUEBLO $\therefore \quad$ COLORADO}

